Prepared in cooperation with the Kansas Water Office, the City of Lawrence, the City of Olathe, the City of Topeka, and Johnson County WaterOne

\title{
Water-Quality Conditions with an Emphasis on Cyanobacteria and Associated Toxins and Taste- and-Odor Compounds in the Kansas River, Kansas, July 2012 through September 2016
}

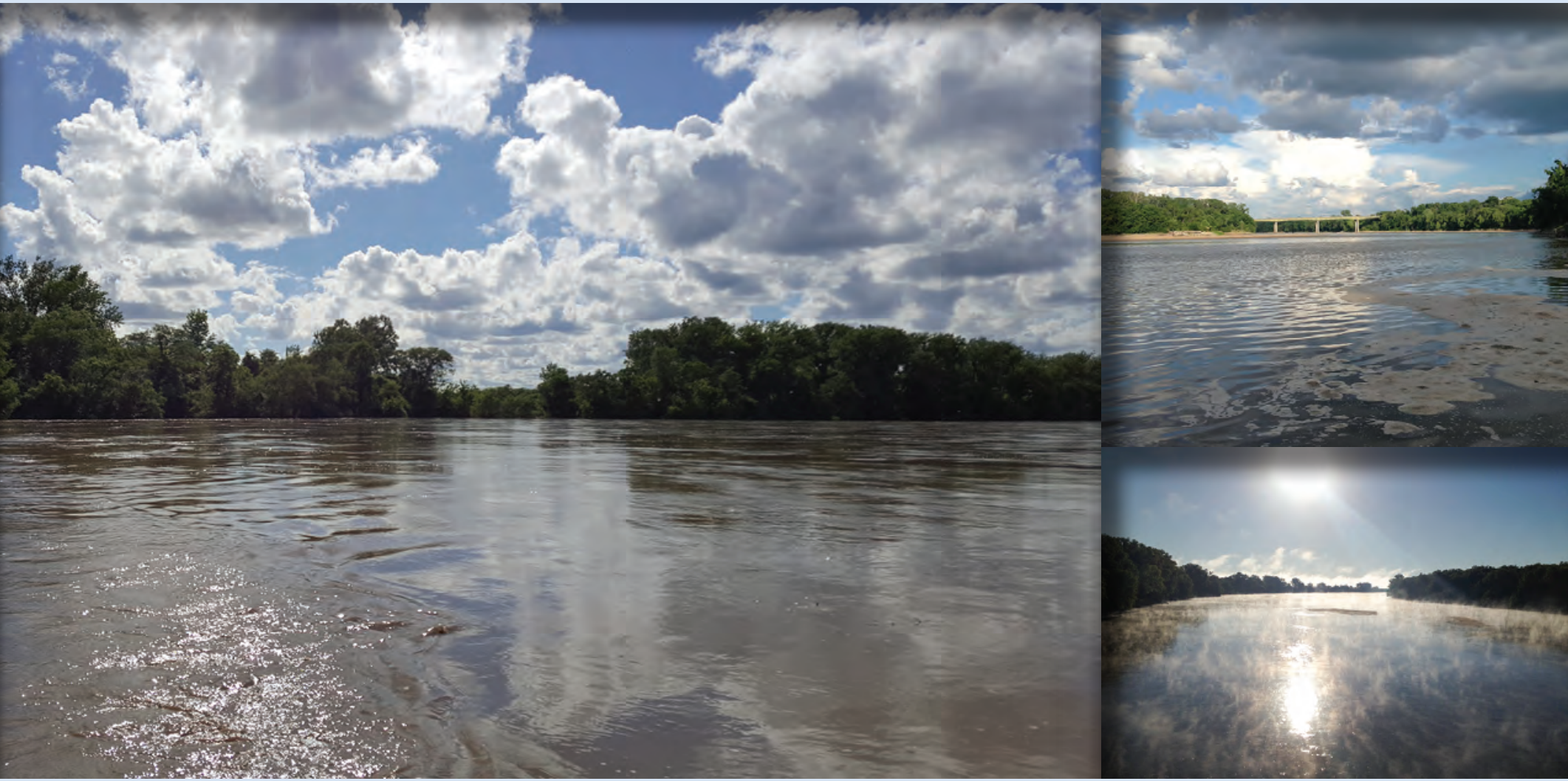

Scientific Investigations Report 2018-5089 
Cover (front). Photographs showing the Kansas River at De Soto (left; by T. Williams, U.S. Geological Survey [USGS], May 28, 2016); the Kansas River at De Soto (right, upper; by J. Graham, USGS, May 30, 2014); and the Kansas River at Wamego (right, lower; by J. Graham, USGS, September 22, 2014).

Cover (back). Photographs showing a USGS hydrologist inspecting the gage house at Kansas River at De Soto (upper; by J. Graham, USGS, May 30, 2014); a USGS hydrologist taking a sample through the ice at Kansas River at De Soto (middle, by G. Foster, USGS, February 10, 2014); and USGS hydrologists returning from sampling on the Kansas River at De Soto (lower, by J. Graham, USGS, June 2, 2014). 


\section{Water-Quality Conditions with an Emphasis on Cyanobacteria and Associated Toxins and Taste-and- Odor Compounds in the Kansas River, Kansas, July 2012 through September 2016}

By Jennifer L. Graham, Guy M. Foster, Thomas J. Williams, Matthew D. Mahoney, Madison R. May, and Keith A. Loftin

Prepared in cooperation with the Kansas Water Office, the City of Lawrence, the City of Olathe, the City of Topeka, and Johnson County WaterOne

Scientific Investigations Report 2018-5089 


\title{
U.S. Department of the Interior \\ RYAN K. ZINKE, Secretary
}

\author{
U.S. Geological Survey \\ James F. Reilly II, Director
}

U.S. Geological Survey, Reston, Virginia: 2018

For more information on the USGS - the Federal source for science about the Earth, its natural and living resources, natural hazards, and the environment-visit https://www.usgs.gov or call 1-888-ASK-USGS.

For an overview of USGS information products, including maps, imagery, and publications,

visit https://store.usgs.gov.

Any use of trade, firm, or product names is for descriptive purposes only and does not imply endorsement by the U.S. Government.

Although this information product, for the most part, is in the public domain, it also may contain copyrighted materials as noted in the text. Permission to reproduce copyrighted items must be secured from the copyright owner.

Suggested citation:

Graham, J.L., Foster, G.M., Williams, T.J., Mahoney, M.D., May, M.R., and Loftin, K.A., 2018, Water-quality conditions with an emphasis on cyanobacteria and associated toxins and taste-and-odor compounds in the Kansas River, Kansas, July 2012 through September 2016: U.S. Geological Survey Scientific Investigations Report 2018-5089, 55 p., https:// doi.org/10.3133/sir20185089.

ISSN 2328-031X (print)

ISSN 2328-0328 (online) 


\section{Contents}

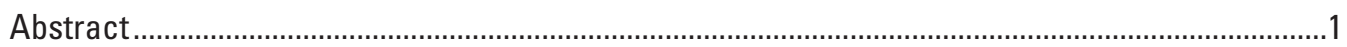

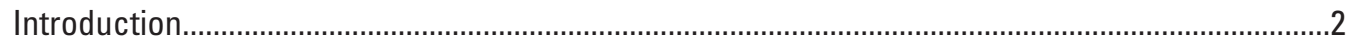

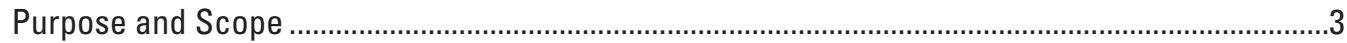

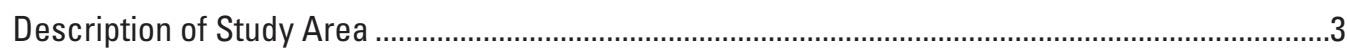

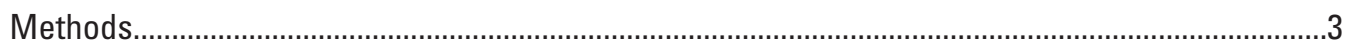

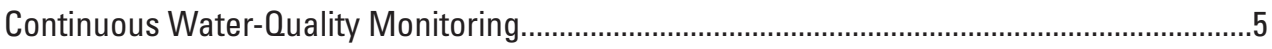

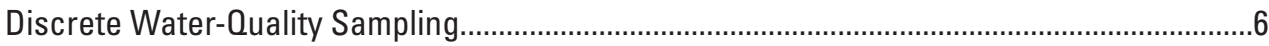

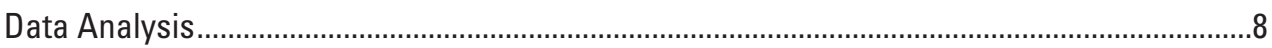

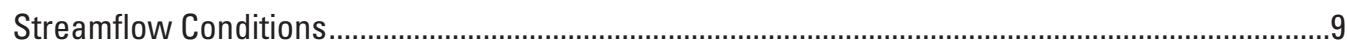

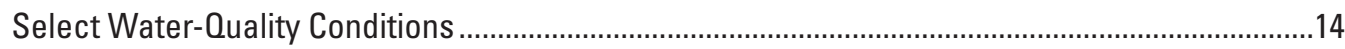

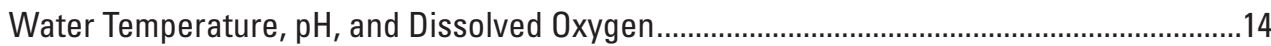

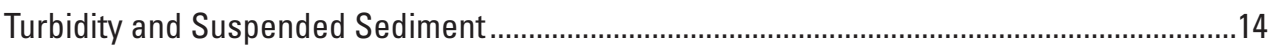

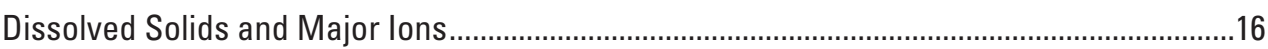

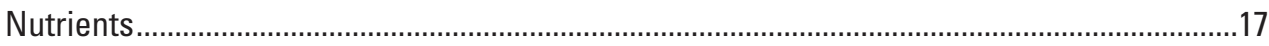

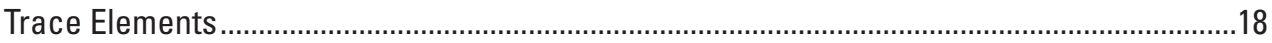

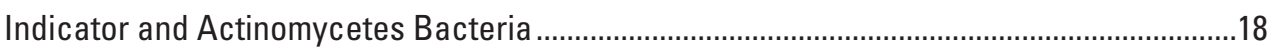

Cyanobacteria, Cyanotoxins, and Taste-and-Odor Compounds ..................................................18

Algal Biomass and Community Composition.......................................................................19

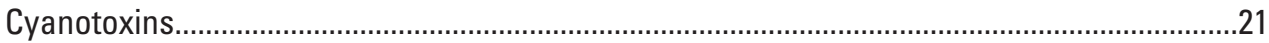

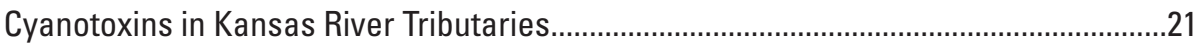

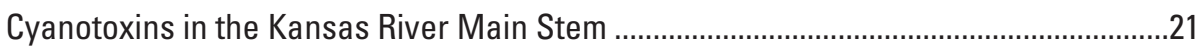

Taste-and-Odor Compounds ...........................................................................................2

Geosmin and 2-Methylisoborneol in Kansas River Tributaries .....................................23

Geosmin and 2-Methylisoborneol in the Kansas River Main Stem...............................24

Co-Occurrence of Cyanotoxins and Taste-and-Odor Compounds ...........................................25

Environmental Factors Associated with Occurrence of Cyanotoxins and Taste-and-Odor

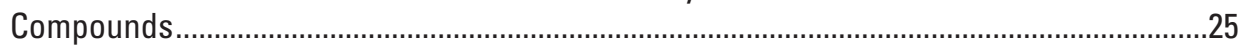

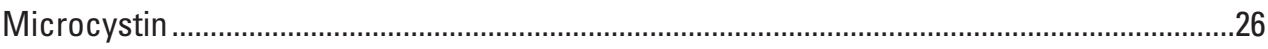

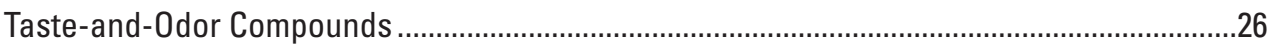

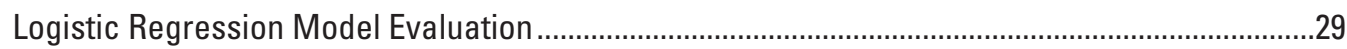

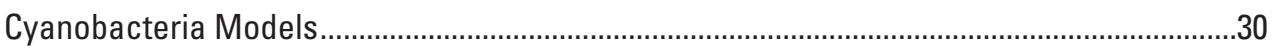

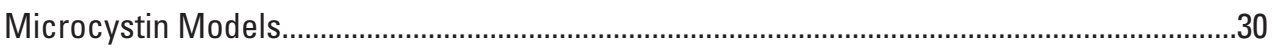

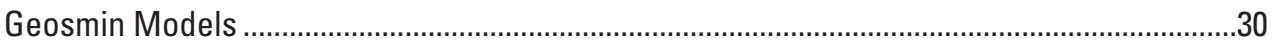

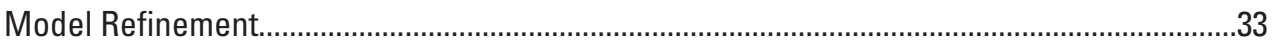

Summary

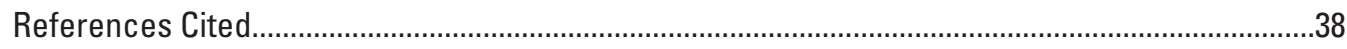

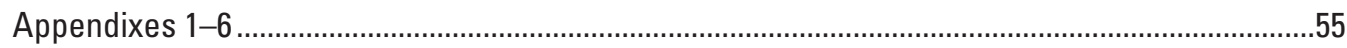




\section{Figures}

1. Map showing location of reservoirs, U.S. Geological Survey streamgages, and discrete water-quality sampling sites in the lower Kansas River Basin..... . .4

2. Graph showing duration curves for discrete water-quality sample collection with respect to streamflow at the Kansas River at Wamego, Kansas, and Kansas River at De Soto, Kansas, streamgages...

3. Graphs showing duration curves for overall and annual streamflows during January 2012 through December 2016

4. Graphs showing contribution of upstream reservoirs and other sources to streamflow in the Kansas River during January 2012 through December 2016

5. Graphs showing duration curves for continuously measured water-quality constituents at the Kansas River at Wamego, Kansas, and Kansas River at De Soto, Kansas, streamgages during July 2012 through September 2016.

6. Graph showing monthly patterns in cyanobacterial abundance at the Kansas River at Wamego, Kansas, and Kansas River at De Soto, Kansas, streamgages during July 2012 through September 2016.

7. Graphs showing occurrence of toxins and taste-and-odor compounds at the Kansas River at Wamego, Kansas; Kansas River at De Soto, Kansas; Republican River at Junction City, Kansas; Big Blue River near Manhattan, Kansas; and Delaware River at Perry, Kansas, streamgages during July 2012 through September 2016.

8. Graphs showing co-occurrence of microcystin and taste-and-odor compounds in samples at the Kansas River at Wamego, Kansas; Kansas River at De Soto, Kansas; Republican River at Junction City, Kansas; Big Blue River near Manhattan, Kansas; and Delaware River at Perry, Kansas, streamgages collected during July 2012 through September 2016.

9. Graphs showing performance of logistic regression models estimating the probability of cyanobacterial occurrence above thresholds of concern at sites on the Kansas River during July 2012 through September 2016

10. Graphs showing performance of logistic regression models estimating the probability of microcystin occurrence above a threshold of concern at sites on the Kansas River during July 2012 through September 2016

11. Graphs showing performance of logistic regression models estimating the probability of geosmin occurrence above a threshold of concern at sites on the Kansas River during July 2012 through September 2016

\section{Tables}

1. Streamflow summary statistics for the Kansas River at Wamego, Kansas, and Kansas River at De Soto, Kansas, streamgages during January 2012 through December 2016.

2. Seasonal and annual means for discretely collected and continuously measured water-quality constituents at the Kansas River at Wamego, Kansas, and Kansas River at De Soto, Kansas, streamgages during July 2012 through September 2016.......44

3. Potential cyanotoxin and taste-and-odor producing cyanobacteria in the Kansas River during July 2012 through September 2016 
4. Summary statistics for cyanobacterial toxins and taste-and-odor compounds at the Kansas River at Wamego, Kansas, and Kansas River at De Soto, Kansas, streamgages during July 2012 through September 2016

5. Selected differences in environmental conditions during microcystin, geosmin, and 2-methylisoborneol events at the Kansas River at Wamego, Kansas, and Kansas River at De Soto, Kansas, streamgages during July 2012 through September 2016.

\section{Conversion Factors}

International System of Units to U.S. customary units

\begin{tabular}{|c|c|c|}
\hline Multiply & By & To obtain \\
\hline \multicolumn{3}{|c|}{ Length } \\
\hline micrometer (m) & 0.0001 & centimeter $(\mathrm{cm})$ \\
\hline \multicolumn{3}{|c|}{ Area } \\
\hline hectare (ha) & 0.003861 & square mile $\left(\mathrm{mi}^{2}\right)$ \\
\hline square kilometer $\left(\mathrm{km}^{2}\right)$ & 0.3861 & square mile $\left(\mathrm{mi}^{2}\right)$ \\
\hline \multicolumn{3}{|c|}{ Volume } \\
\hline liter (L) & 33.81402 & ounce, fluid (fl. oz) \\
\hline milliliter (mL) & 0.0338 & ounce, fluid (fl. oz) \\
\hline cubic meter $\left(\mathrm{m}^{3}\right)$ & 0.0008107 & acre-foot (acre-ft) \\
\hline \multicolumn{3}{|c|}{ Flow rate } \\
\hline cubic meter per second $\left(\mathrm{m}^{3} / \mathrm{s}\right)$ & 35.31 & cubic foot per second $\left(\mathrm{ft}^{3} / \mathrm{s}\right)$ \\
\hline \multicolumn{3}{|c|}{ Mass } \\
\hline milligram (mg) & 0.00003527 & ounce, avoirdupois (oz) \\
\hline microgram $(\mu g)$ & 0.00000003527 & ounce, avoirdupois (oz) \\
\hline nanogram (ng) & 0.00000000003527 & ounce, avoirdupois (oz) \\
\hline
\end{tabular}

Temperature in degrees Celsius $\left({ }^{\circ} \mathrm{C}\right)$ may be converted to degrees Fahrenheit

$$
\left({ }^{\circ} \mathrm{F}\right) \text { as }{ }^{\circ} \mathrm{F}=\left(1.8 \times{ }^{\circ} \mathrm{C}\right)+32 .
$$

\section{Datum}

Horizontal coordinate information is referenced to the North American Datum of 1983 (NAD 83). 


\section{Supplemental Information}

Concentrations of chemical constituents in water are given in either milligrams per liter (mg/L), micrograms per liter $(\mu \mathrm{g} / \mathrm{L})$, or nanograms per liter $(\mathrm{ng} / \mathrm{L})$.

Phytoplankton abundances are given in cells per milliliter (cells $/ \mathrm{mL}$ )

Specific conductance is given in microsiemens per centimeter at 25 degrees Celsius $(\mu \mathrm{S} / \mathrm{cm}$ at $25 \mathrm{C})$.

\section{Abbreviations}

$\begin{array}{ll}\text { ANCOVA } & \text { analysis of covariance } \\ \text { AVLD } & \text { absolute value logarithmic difference } \\ \text { CFU } & \text { colony forming unit } \\ \text { Chl } & \text { laboratory-measured chlorophyll } \\ \text { E. coli } & \text { Escherichia coli } \\ \text { EPA } & \text { U.S. Environmental Protection Agency } \\ \text { fChl } & \text { sensor-measured chlorophyll fluorescence } \\ \text { FNU } & \text { formazin nephelometric units } \\ \text { KDHE } & \text { Kansas Department of Health and Environment } \\ \text { MIB } & \text { 2-methylisoborneol } \\ \text { NWIS } & \text { National Water Information System } \\ \text { PDWR } & \text { primary drinking-water regulations } \\ \text { ppm } & \text { parts per million } \\ p \text {-value } & \text { probability value } \\ \text { QA } & \text { quality assurance } \\ \text { OC } & \text { quality control } \\ R^{2} & \text { coefficient of determination } \\ R_{s} & \text { Spearman rank-correlation coefficient } \\ \text { RPD } & \text { relative percentage difference } \\ \text { SDWR } & \text { secondary drinking-water regulations } \\ \text { SSC } & \text { suspended-sediment concentration } \\ \text { TN } & \text { total nitrogen } \\ \text { TP } & \text { total phosphorus } \\ \text { TPPC } & \text { threshold probability for positive classification } \\ \text { USGS } & \text { U.S. Geological Survey } \\ & \\ & \end{array}$




\title{
Water-Quality Conditions with an Emphasis on Cyanobacteria and Associated Toxins and Taste-and-Odor Compounds in the Kansas River, Kansas, July 2012 through September 2016
}

\author{
By Jennifer L. Graham, Guy M. Foster, Thomas J. Williams, Matthew D. Mahoney, Madison R. May, and Keith
} A. Loftin

\section{Abstract}

Cyanobacteria cause a multitude of water-quality concerns, including the potential to produce toxins and taste-andodor compounds that may cause substantial economic and public health concerns, and are of particular interest in lakes, reservoirs, and rivers that are used for drinking-water supply. Extensive cyanobacterial blooms typically do not develop in the Kansas River; however, reservoirs in the lower Kansas River Basin occasionally develop blooms that may affect downstream water quality. During July 2012 through September 2016, continuous and (or) discrete water-quality data were collected at several sites (Wamego, De Soto, and three main reservoir-fed tributaries) on the Kansas River to characterize the sources, frequency and magnitude of occurrence, and causes of cyanobacteria, cyanobacterial toxins, and taste-andodor compounds and to develop a real-time notification system of changing water-quality conditions that may affect drinkingwater treatment.

Algal biomass, as estimated by chlorophyll, was consistently higher at the downstream De Soto site than the upstream Wamego site. Higher algal biomass at the De Soto site likely was caused by algal growth during downstream transport without major losses due to grazing by aquatic organisms or other processes. Algal biomass at the Wamego and De Soto sites was negatively correlated with streamflow and total and bioavailable nutrient concentrations. The negative association between algal biomass and nutrients in the Kansas River likely reflects the relatively strong positive association between nutrient concentrations and streamflows.

Cyanobacteria were relatively common in the Kansas River but rarely dominated the algal community. Like overall algal biomass, cyanobacterial abundances typically were higher at the De Soto site than the Wamego site. Cyanobacterial abundances generally peaked in late summer or early fall (July through October), with smaller peaks occasionally observed in spring (April through May). Cyanobacteria in the Kansas River rarely exceeded 20,000 cells per milliliter, the abundance at which cyanobacteria may become a concern for drinking-water treatment. Relations between cyanobacterial abundance and streamflow, turbidity, and nutrients in the Kansas River were similar to those between chlorophyll and total phytoplankton abundance, indicating the same processes that influence overall algal biomass and dynamics also are influencing cyanobacteria.

The cyanotoxin microcystin was detected in about 27 percent of the samples collected from Kansas River tributary and main-stem sites. Cylindrospermopsin was detected in one sample from the De Soto site. Microcystin occurrence and concentration were similar between the Wamego and De Soto sites. Concentrations exceeded the U.S. Environmental Protection Agency health advisory guidance values for finished drinking water of 0.3 (for bottle-fed infants and pre-school children) and 1.6 micrograms per liter $(\mu \mathrm{g} / \mathrm{L}$; for school-age children and adults) in 6 percent or less of samples collected. These guidance values are for finished drinking water and are not directly applicable to observed environmental concentrations but do provide a benchmark for comparison. Microcystin was detected most often and had the highest concentrations during summer. Though seasonal patterns in microcystin occurrence were generally consistent, seasonal maxima varied by an order of magnitude across years.

The taste-and-odor compounds geosmin and 2-methylisoborneol (MIB) were detected in about 78 and 43 percent of samples, respectively, collected across all sites (main stem and tributaries). Geosmin and MIB occurrence and concentration varied considerably between the Wamego and De Soto sites. Geosmin was detected in about 67 percent of Wamego samples and 81 percent of De Soto samples. The human detection threshold of 5 nanograms per liter (ng/L) was exceeded for geosmin in about 11 and 17 percent of the samples collected at the Wamego and De Soto sites, respectively. Geosmin 
was detected during all months of the year at both sites, and there were no clear seasonal patterns. MIB was detected less frequently in the Kansas River than geosmin and was observed in about 42 percent of Wamego samples and 33 percent of De Soto samples. Concentrations exceeded $5 \mathrm{ng} / \mathrm{L}$ in about 7 and 5 percent of samples from the Wamego and De Soto sites, respectively. As observed for geosmin, there were no clear seasonal patterns in MIB occurrence or concentration.

There seems to be a connection between microcystin detections in the Kansas River and occurrence of microcystin in upstream reservoirs (and tributary streams). Microcystin concentrations greater than $0.3 \mu \mathrm{g} / \mathrm{L}$ may be likely during the summer when streamflow is less than 3,000 cubic feet per second $\left(\mathrm{ft}^{3} / \mathrm{s}\right)$ and contributions from Milford Lake exceed about 30 percent of total flow in the Kansas River. Observed microcystin concentrations typically were higher at the De Soto site than the Wamego or tributary sites during 2012 through 2016, indicating cyanobacteria may continue to grow and produce microcystin once introduced to the Kansas River.

The spatial and temporal patterns in geosmin and MIB occurrence and concentration were more complex than microcystin. There were no clear connections between geosmin and MIB occurrence in the Kansas River and potential upstream reservoir (or tributary stream) sources. Likewise, there was not a clear relation between algal biomass, cyanobacteria, or actinomycetes bacteria and taste-and-odor events in the Kansas River. Geosmin and MIB were not strongly correlated with any measured environmental variable at either Kansas River site.

Continuous water-quality data may be used independently or in combination with regression models to provide information on changing water-quality conditions that may affect drinking-water treatment processes or recreational activities on the Kansas River. For example, logistic regression model outputs and continuous water-quality data may both be indicative of the potential for microcystin events. Logistic regression models that are estimating a high probability of microcystin occurrence at concentrations above $0.1 \mu \mathrm{g} / \mathrm{L}$ can be used as one indicator. Streamflows less than 3,000 ft3 $3 / \mathrm{s}$ during upstream reservoir releases during periods with low turbidity and increased chlorophyll fluorescence, specific conductance, and $\mathrm{pH}$ values may also be indicative of microcystin events. Advanced or near-real-time notification may inform proactive, rather than reactive, management strategies when water-quality conditions are changing rapidly or are likely to cause cyanobacteria-related events.

\section{Introduction}

Cyanobacteria (also called blue-green algae) cause a multitude of water-quality concerns, including the potential to produce toxins and taste-and-odor compounds. Toxins and taste-and-odor compounds may cause substantial economic and public health concerns and are of particular interest in lakes, reservoirs, and rivers that are used for drinking-water supply (Graham and others, 2016). Cyanobacterial toxins (hereafter referred to as "cyanotoxins") have been implicated in human and animal illness and death in at least 43 States in the United States, including Kansas (Graham and others, 2016; Trevino-Garrison and others, 2015). In 2015, the U.S. Environmental Protection Agency (EPA) established health advisory values for the cyanotoxins microcystin and cylindrospermopsin in finished drinking water. The 10-day health advisory values for microcystin in finished drinking water are 0.3 microgram per liter $(\mu \mathrm{g} / \mathrm{L})$ for young children (less than $[<] 6$ years old) and $1.6 \mu \mathrm{g} / \mathrm{L}$ for all other ages. The 10-day health advisory values for cylindrospermopsin are $0.7 \mu \mathrm{g} / \mathrm{L}$ for young children and $3.0 \mu \mathrm{g} / \mathrm{L}$ for all other ages (U.S. Environmental Protection Agency, 2015). Unlike cyanotoxins, tasteand-odor compounds have no known effects on human health, and there are no regulations or advisory values for these compounds. Aesthetic issues are associated with taste-andodor compounds at low concentrations (5 to 10 nanograms per liter [ng/L]), and remedial actions commonly are implemented as soon as taste or odor is detected in a drinking-water supply (Taylor and others, 2005).

The Kansas River and its associated alluvial aquifer are primary sources of drinking water for about 800,000 people in northeastern Kansas (Graham and others, 2012). In addition to serving as a drinking-water supply, designated uses of the Kansas River include recreation, aquatic life support, food procurement, groundwater recharge, irrigation, and livestock watering (Kansas Department of Health and Environment, 2011). All of these designated uses potentially may be affected by cyanobacteria (Chorus and Bartram, 1999; Hudnell, 2008). Extensive cyanobacterial blooms typically do not develop in the Kansas River; however, reservoirs in the lower Kansas River Basin occasionally develop blooms that may affect downstream water quality (Graham and others, 2012).

Water releases from Milford Lake during a toxic cyanobacterial bloom in late August 2011 prompted concerns about potential for downstream transport. Water samples were collected weekly by the U.S. Geological Survey (USGS) during September and October 2011 to characterize the transport of cyanotoxins and taste-and-odor compounds from upstream reservoirs to the Kansas River (Graham and Others, 2012). Within a week after initial reservoir releases in late August 2011, the cyanotoxin microcystin and the taste-and-odor compounds geosmin and 2-methylisoborneol (MIB) were detected throughout a 174-mile reach of the Kansas River from Junction City, Kansas (Kans.), to Kansas City, Kans., and these compounds remained detectable throughout the reach until mid-October. Patterns in microcystin occurrence and concentration at the Kansas River tributary and main-stem sites indicated that Milford Lake was the source of microcystin in the Kansas River. The source of taste-and-odor compounds was not as evident, possibly because multiple tributaries contributed taste-and-odor compounds to the Kansas River. Using simple dilution models, measured concentrations of cyanobacteria and associated compounds were substantially higher 
than expected concentrations at some sites and substantially lower at others, with unique spatial and temporal patterns for individual compounds. Thus, simple dilution models were not sufficient to describe the downstream transport of cyanobacteria, cyanotoxins, and taste-and-odor compounds in the Kansas River (Graham and others, 2012). The September through October 2011 study (Graham and others, 2012) was one of the first to quantitatively document the transport of cyanobacteria and associated compounds during reservoir releases and the improved understanding of cyanotoxin and taste-and-odor compound fate and transport downstream from reservoirs in Kansas. Since July 2012, the USGS, in cooperation with the Kansas Water Office, the City of Lawrence, the City of Olathe, the City of Topeka, and Johnson County WaterOne, has collected discrete and continuously measured water-quality data at two sites on the Kansas River to better characterize the sources, frequency and magnitude of occurrence, and causes of cyanobacteria, cyanotoxins, and taste-and-odor compounds and to develop a real-time notification system of changing water-quality conditions that may affect drinking-water treatment.

\section{Purpose and Scope}

The purpose of this report is to (1) describe water-quality conditions, with an emphasis on cyanobacteria and associated toxins (microcystin) and taste-and-odor compounds (geosmin and MIB), in the Kansas River during July 2012 through September 2016; (2) describe the environmental factors associated with the occurrence of cyanobacteria and associated toxins and taste-and-odor compounds in the Kansas River during July 2012 through September 2016; and (3) evaluate previously published logistic regression models that used continuous water-quality data to estimate the probability of cyanobacteria, microcystin, and geosmin occurrence above relevant thresholds in the Kansas River (Foster and Graham, 2016). Detailed analyses of all regression models published by Foster and Graham (2016) and all water-quality data collected from the Kansas River during July 2012 through September 2016 are beyond the scope of this report. Quantification of cyanobacteria, cyanotoxins, and taste-and-odor compounds, and the conditions under which they are most likely to occur in the Kansas River will provide drinking-water suppliers and the State of Kansas a better understanding of associated water-quality concerns in the river. The logistic regression models evaluated in this report may provide useful indicators of cyanobacteria, microcystin, and geosmin occurrence in the Kansas River. In addition, the methods used in this study could be applied to other sites regionally, nationally, and globally. This study was cooperatively funded in part by the Kansas Water Office through the State Water Plan, the City of Lawrence, the City of Olathe, the City of Topeka, Johnson County WaterOne, and the USGS cooperative matching funds through the National Water Quality Program.

\section{Description of Study Area}

The Kansas River Basin has an area of 60,097 square miles $\left(\mathrm{mi}^{2}\right)$ and includes most of the northern one-half of Kansas and parts of Nebraska and Colorado. The Kansas River is formed by the confluence of the Smoky Hill and Republican Rivers, near Junction City, Kans., and flows about 174 miles east into the Missouri River (not shown), at Kansas City, Kans. (fig. 1). The area downstream from the Smoky Hill and Republican Rivers confluence commonly is called the lower Kansas River Basin, which has an area of 5,448 $\mathrm{mi}^{2}$ and forms the study area. Streamflow in the study area is regulated by four large reservoirs (Milford Lake, Tuttle Creek Lake, Perry Lake, and Clinton Lake; fig. 1). All four are bottom-release reservoirs constructed in the 1960s and 1970s for flood control but also are used for other purposes including recreation and drinking-water supply (either directly or through releases for downstream use; U.S. Army Corps of Engineers, 2017). Although urban development represents a small part of total land use in the study area (about 9 percent of land use; Fry and others, 2011), major urban and industrial areas are located along the Kansas River at Manhattan, Topeka, Lawrence, and Kansas City, Kans. (fig. 1). These cities, in addition to many smaller communities, withdraw water from the Kansas River and associated alluvial aquifer for municipal water supply. More detailed descriptions of the character of the lower Kansas River Basin have been published elsewhere (Rasmussen and others, 2005; Rasmussen and Christensen, 2005; and Graham and others, 2012).

Two main-stem sites were sampled to describe water-quality conditions in the Kansas River during July 2012 through September 2016 (fig. 1). The Kansas River at Wamego, Kans., streamgage (USGS station number 06887500; hereafter referred to as the "Wamego site") has a drainage area of 55,280 $\mathrm{mi}^{2}$ and is located downstream from Milford and Tuttle Creek reservoirs (fig. 1). The Kansas River at De Soto, Kans., streamgage (USGS station number 06892350; hereafter referred to as the "De Soto site") has a drainage area of $59,756 \mathrm{mi}^{2}$. The De Soto site is located about 98 river miles downstream from the Wamego site and is downstream from all four large reservoirs (fig. 1). Samples also were collected on the tributary Republican, Big Blue, and Delaware Rivers between 2.3 and 4.9 miles downstream from the dams forming Milford, Tuttle Creek, and Perry Lakes, respectively. The Wakarusa River downstream from Clinton Lake was not sampled because it did not contribute substantively to streamflow in the Kansas River during the study period.

\section{Methods}

Continuous real-time and discrete water-quality data have been collected at the Wamego and De Soto sites since July 2012. Additionally, event-based discrete water-quality 

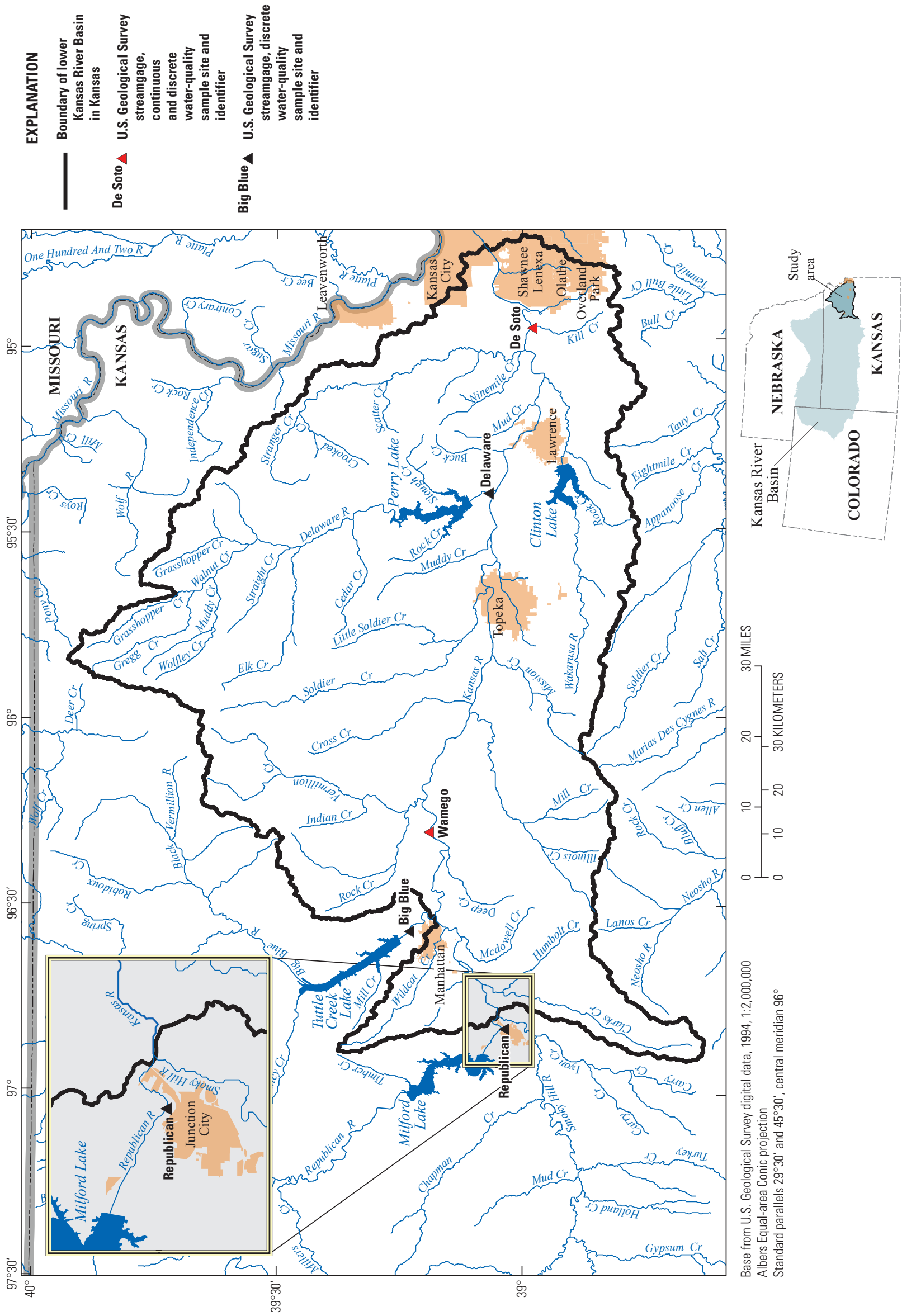

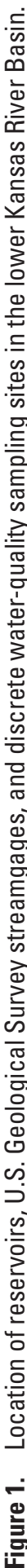


samples have been collected at three reservoir outflow sites that are tributaries to the Kansas River: Republican River at Junction City, Kans., streamgage (downstream from Milford Lake; USGS station number 06857100), Big Blue River near Manhattan, Kans., streamgage (downstream from Tuttle Creek Lake; USGS station number 06887000), and Delaware River at Perry, Kans., streamgage (downstream from Perry Lake; USGS station number 06890900). Continuous and discrete water-quality data collected by the USGS at these sites during July 2012 through September 2016 were used to characterize water-quality conditions in the lower Kansas River Basin and to evaluate previously published (Foster and Graham, 2016) logistic regression models developed to estimate the probability of cyanobacteria, microcystin, and geosmin occurrence above relevant thresholds at the Wamego and De Soto sites. Because of the emphasis on cyanobacteria and associated toxins and taste-and-odor compounds, other regression models published by Foster and Graham (2016) are not evaluated in this report.

\section{Continuous Water-Quality Monitoring}

Continuous (15-minute intervals) streamflow and waterquality data were collected from the Wamego and De Soto sites. Streamgages have been operating at the Wamego and De Soto sites since January 1919 and July 1917, respectively (U.S. Geological Survey, 2018). Streamflow at both sites was measured using standard USGS methods (Sauer and Turnipseed, 2010; Turnipseed and Sauer, 2010). Streamflow data are available through the USGS National Water Information System (NWIS) database (U.S. Geological Survey, 2018).

Continuous water-quality data were collected at the Wamego and De Soto sites during July 1999 through September 2004 (Rasmussen and others, 2005). Continuous waterquality monitors were reinstalled at the Wamego and De Soto sites in August and July 2012, respectively. Monitors were installed near the centroid of the stream cross-section to best represent conditions across the width of the stream and were maintained in accordance with standard USGS procedures (Wagner and others, 2006; Bennett and others, 2014). All continuous water-quality data are available through the NWIS database (U.S. Geological Survey, 2018).

During July 2012 through June 2014, sites were equipped with YSI 6600 V2 water-quality monitors to measure water temperature, $\mathrm{pH}$, dissolved oxygen (YSI 6150 optical dissolved oxygen sensor), turbidity (YSI 6136 sensor), specific conductance, and chlorophyll fluorescence (fChl; YSI model 6025 sensor). In June 2014, Xylem YSI EXO water-quality monitors were installed and measured the same parameters as the YSI 6600 V2. All data are considered comparable during the period of record despite changes in the water-quality monitors during the study, with the exception of fChl.

Relative percentage difference (RPD) was used to estimate differences in fChl sensor readings between sensor types. RPD was calculated using the following equation:

$$
R P D=100\left[|A-B| /\left(\frac{A+B}{2}\right)\right],
$$

where

$A$ and $B$ are concentrations in each replicate pair (Zar, 1999).

Based on data collected from both sites, the median RPD between fChl (reported as micrograms per liter) measured by the YSI 6025 and EXO sensors was 37 percent $(n=26)$, and the median difference in values was $11.5 \mu \mathrm{g} / \mathrm{L}$. In general, fChl values measured by the EXO sensors were higher than those measured by the YSI 6025 (median ratio of EXO:YSI 6025 values $=1.4$ ). Though there was a linear association between YSI 6025 and EXO measured fChl (coefficient of determination $\left[R^{2}\right]=0.98, n=26$ ), available data were not considered sufficient to develop a relation to convert values between the two sensors. Therefore, sensor-measured fChl data were corrected to laboratory-measured chlorophyll (Chl) samples for the YSI 6025 and EXO sensors at the Wamego and De Soto sites (see appendixes 1 through 4). Corrected sensor-based fChl data are used to describe among-site and seasonal patterns in chlorophyll concentrations.

There are documented differences in the YSI 6136 and EXO turbidity sensors (Yellow Springs Instruments, 2012). Based on data collected from both sites, the median difference in turbidity values measured by the YSI 6136 and EXO sensors was 2.5 formazin nephelometric units (FNU) $(n=29$; range $=0.26$ to 17.1 ; mean $=4.1$ ), and the median RPD was 11 percent $(n=29$; range $=1.3$ to 83 percent; mean $=15$ percent) (appendix figs. 5.1 to 5.3). The relations between Hach 2100AN turbidity values and turbidity values measured by the YSI 6136 and EXO sensors also were evaluated to determine differences between sensors. Analysis of covariance (ANCOVA) was used to determine if the relation between Hach 2100AN turbidity values and turbidity values measured by the YSI 6136 and EXO sensors were different (appendix fig. 5.4). The ANCOVA test is used to determine if the slopes and intercepts of two or more regression lines are statistically significant (Helsel and Hirsch, 2002). The F-value, also called the sample variance ratio, is calculated as a nested F-statistic comparing the variance between regression models. Significance for these analyses was set at a probability value ( $p$-value) of $<0.05$. The slopes of the two relations were not statistically different (YSI 6136 slope $=0.82$; EXO slope $=0.76$; $p$-value $=0.38$ ); however, though the difference between intercepts was small (YSI 6136 $=6.52 ; \mathrm{EXO}=8.14$ ) it was statistically significant ( $p$-value $=0.04$ ). Given the documented differences between the two sensors (Yellow Springs Instruments, 2012), this difference is expected. The median difference in values between turbidity measured by the HACH 2100AN and the YSI 6136 and EXO sensors were 2.6 and $5.5 \mathrm{FNU}$, respectively (YSI 6136: $n=55$, range $=0.02$ to 202 , mean $=12.6$; EXO: $n=85$, range $=0.10$ to 164 , mean $=20$ ). At turbidities $<200$ FNU, the difference between most measured turbidity values was $<20 \mathrm{FNU}$, regardless of sensor type (appendix fig. 5.5). 
About 90 percent of the turbidity data collected at the Wamego $(n=135,068)$ and De Soto $(n=138,287)$ sites were $<200$ FNU during July 2012 through September 2016. The median RPDs between turbidity measured by the HACH $2100 \mathrm{AN}$ and the YSI 6136 and EXO sensors were 21 and 15 percent, respectively (YSI 6136: $n=55$, range $=1.6$ to 200 percent, mean $=32$ percent; EXO: $n=85$, range $=0.24$ to 200 percent, mean $=20$ percent) (appendix fig. 5.6). For the purposes of this report, turbidity data from the two sensors were considered comparable because differences between the YSI 6136 and EXO turbidity sensors were small at turbidities $<200 \mathrm{FNU}$ and the relations between each sensor and the HACH 2100AN were similar. However, future analyses focused specifically on spatial and temporal patterns in turbidity and suspended sediment may want to consider the potential for differences between the two sensors, particularly at turbidities greater than (>) 200 FNU.

Sensor maxima were not exceeded for any of the physicochemical properties measured except for the YSI 6136 turbidity sensor (operable range 0-1,000 FNU) during runoff events in July 2013, April 2014, and June 2014 at the Wamego site (maximum turbidity=1,180 FNU). At the De Soto site, the same sensor model also exceeded sensor maxima during runoff events in April-May 2013, August 2013, and April 2014 (maximum turbidity=1,330 FNU). During July 2012 through September 2016, approximately 90 percent of the continuous data at the Wamego and De Soto sites were rated as excellent (requiring corrections of less than plus or minus $[ \pm] 5$ percent), 6 percent were rated as good (requiring corrections of $< \pm 10$ percent), 2 percent were rated as fair (requiring corrections of $< \pm 15$ percent), and 2 percent were rated as poor (requiring corrections of $> \pm 15$ percent) according to the established guidelines (Wagner and others, 2006).

Time-series measurements occasionally were missing or deleted from the dataset during the data quality-assurance/ quality-control (QA/QC) process because of equipment malfunction, excessive fouling caused by environmental conditions, or temporary removal of the sensors due to icy conditions in the river. For the Wamego site, during July 2012 through September 2016, approximately 6 percent of the water temperature and dissolved oxygen records, 8 percent of the specific conductance record, 7 percent of the $\mathrm{pH}$ record, 16 percent of the turbidity record, and 13 percent of the fChl record were missing or deleted. For the De Soto site, during the same time period, approximately 6 percent of the water temperature record, 12 percent of the specific conductance record, 5 percent of the $\mathrm{pH}$ record, 8 percent of the dissolved oxygen record, 19 percent of the turbidity record, and 17 percent of the fChl record were missing or deleted. Missing and deleted data at both sites were primarily due to sensor removal during ice cover and (or) sensor malfunction. Missing waterquality data cannot be estimated and data gaps were not filled. Therefore, duration curves developed using these data are based solely on sensor-measured values.

\section{Discrete Water-Quality Sampling}

During July 2012 through September 2016, discrete water-quality samples at the Wamego and De Soto sites were collected on a biweekly basis during May through October and a monthly basis during November through April. Using this long-term, fixed-schedule sampling approach, discrete water-quality data were collected over a range of streamflow conditions at the Wamego and De Soto sites during July 2012 through September 2016 (fig. 2). Discrete water-quality samples were collected following USGS equal-width-increment methods (U.S. Geological Survey, 2006), unless precluded by ice or extreme cold conditions. During ice or extreme cold conditions, weighted basket or grab samples were collected from the centroid of flow or at the safest possible nearshore location (U.S. Geological Survey, 2006). Samples for bacterial analyses were always collected at the centroid of flow using a weighted basket or grab approach. All water-quality samples were analyzed for suspended-sediment concentration (SSC), dissolved solids and major ions, nutrients (nitrogen and phosphorus species), trace elements, indicator and actinomycetes bacteria, algal biomass, phytoplankton abundance and community composition, the cyanotoxin microcystin, and the taste-and-odor compounds geosmin and MIB. The cyanotoxin cylindrospermopsin also was analyzed during July 2015 through September 2016.

Event-based discrete water-quality samples also were collected during July 2012 through September 2016 at the Wamego and De Soto sites and the three reservoir outflow sites from Milford Lake (Republican River), Tuttle Creek Lake (Big Blue River), and Perry Lake (Delaware River). At least four and as many as six event-based samples were collected per year at each site during scheduled increases in reservoir release, cyanobacterial blooms in the reservoirs, or taste-and-odor or microcystin detections in routine samples collected from the Kansas River at Wamego and De Soto sites. Event-based samples were collected using depth-integrated sampling techniques at the centroid of flow, except during icy or extreme cold conditions when weighted basket or grab samples were collected from the centroid of flow or at the safest possible nearshore location (U.S. Geological Survey, 2006). These samples were analyzed for the cyanotoxin microcystin and the taste-and-odor compounds geosmin and MIB. The cyanotoxin cylindrospermopsin was analyzed during July 2015 through September 2016. All discrete water-quality data (except phytoplankton abundance and community composition), are available through NWIS (U.S. Geological Survey, 2018) and as a USGS data release in Williams and others (2018). Phytoplankton community composition and abundance data are available as a USGS data release in Kramer and others (2018).

Suspended sediment was analyzed as described in Guy (1969) at the USGS Iowa Sediment Laboratory, Iowa City, Iowa. Dissolved solids, major ions, nutrients, and trace elements were analyzed by the USGS National Water Quality Laboratory, Lakewood, Colorado. Analytical methods 


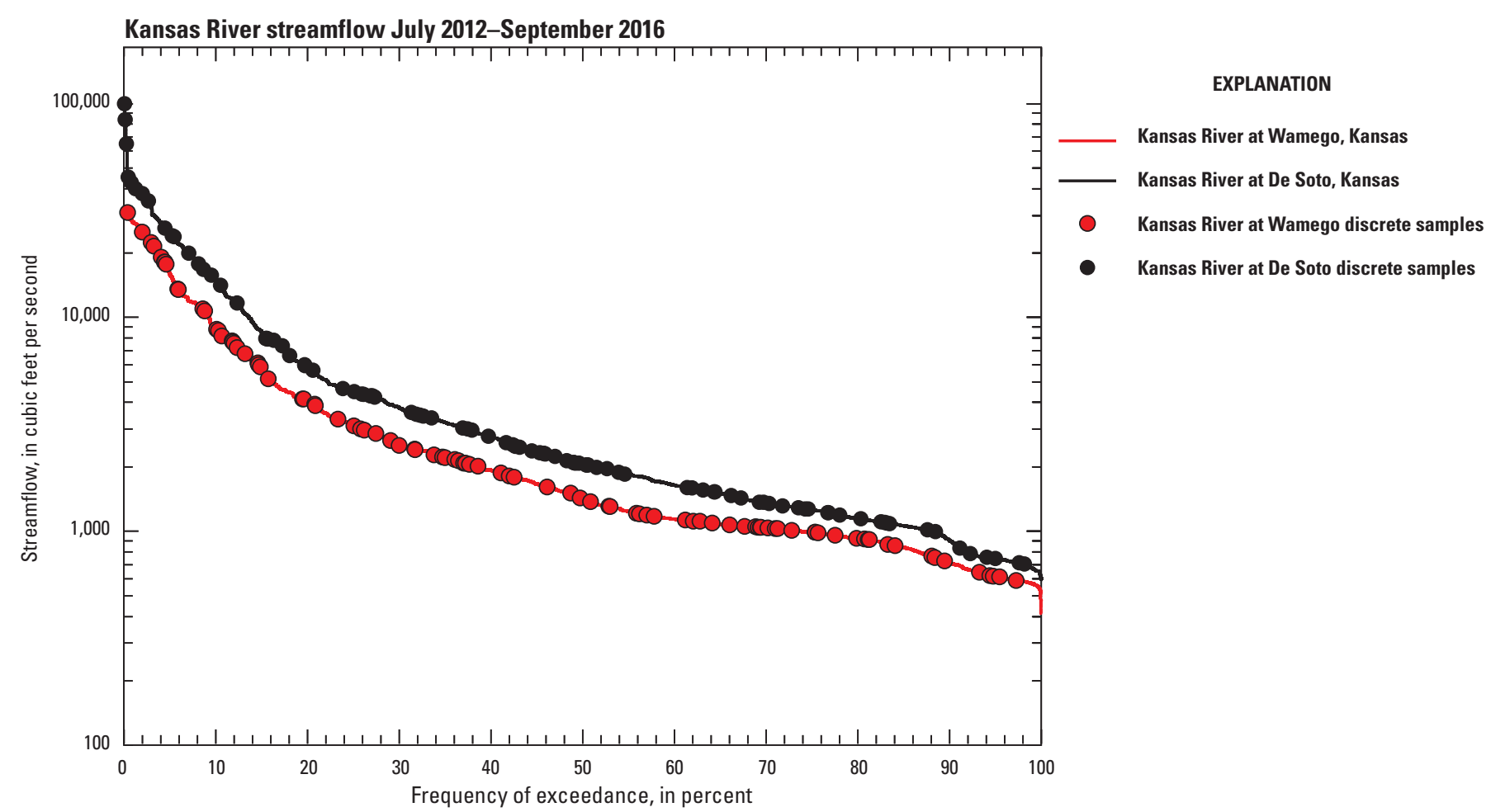

Figure 2. Duration curves for discrete water-quality sample collection with respect to streamflow at the Kansas River at Wamego, Kansas, and Kansas River at De Soto, Kansas, streamgages (U.S. Geological Survey stations 06887500 and 06892350, respectively).

for these constituents are described by Fishman and Friedman (1989). Escherichia coli (E. coli), fecal coliform, and enterococci indicator bacteria were analyzed using membrane filtration methods described by Myers and others (2014) at the USGS Kansas Water Science Center, Lawrence, Kans. Actinomycetes bacteria were analyzed using the standard plate counts method (Rice and others, 2012) at the USGS Ohio Water Microbiology Laboratory, Columbus, Ohio.

Chlorophyll (uncorrected for degradation products) was analyzed fluorometrically at the USGS Kansas Water Science Center, Lawrence, Kans., using EPA Method 445.0 (Arar and Collins, 1997) modified for heated ethanol extraction (Sartory and Grobbelaar, 1984) and a fluorometer equipped with a flow-through cell (Knowlton, 1984). Quality-control procedures using this modified method for chlorophyll analysis are described by Foster and others (2017). Phytoplankton samples were preserved with a 9:1 Lugol's iodine:acetic acid solution and analyzed for taxonomic identification and enumeration by BSA Environmental Service, Inc., Beachwood, Ohio, as described by Graham and others (2017). The cyanotoxins microcystin and cylindrospermopsin were analyzed by the USGS Organic Geochemistry Research Laboratory, Lawrence, Kans. These samples were lysed sequentially by three freezethaw cycles. Following the freeze-thaw cycle, samples were filtered using 0.7-micrometer glass-fiber syringe filters (Loftin and others, 2008) before analysis. Abraxis ${ }^{\circledR}$ enzyme-linked immunosorbent assays were used to measure microcystin and cylindrospermopsin (-adda specific; Fischer and others, 2001). The taste-and-odor compounds geosmin and MIB were analyzed using solid phase microextraction gas chromatography/ mass spectrometry (Zimmerman and others, 2002) by Engineering Performance Solutions, LLC, Jacksonville, Florida.

Cyanotoxins and taste-and-odor compounds may exist in particulate (intracellular) and dissolved (extracellular) forms (Graham and others, 2008). Total concentrations (includes both particulate and dissolved forms) of microcystin, cylindrospermopsin, geosmin, and MIB were measured in all samples. Dissolved concentrations of microcystin and cylindrospermopsin were analyzed when total concentrations were $>0.1 \mu \mathrm{g} / \mathrm{L}$. Similarly, dissolved concentrations of geosmin and MIB were analyzed when total concentrations were $>5 \mathrm{ng} / \mathrm{L}$.

QA/QC samples were collected to evaluate variability in sample collection and processing techniques (Bennett and others, 2014; Mueller and others, 2015). Concurrent replicate samples were collected to estimate variability caused by sample collection and processing methodology. RPD was used to estimate differences in analyte concentrations between concurrent replicate pairs and could not be calculated if one or both of the replicate water-quality samples had a censored value reported (less than the laboratory reporting level). Generally, median RPDs for all constituents met data QA/QC objectives (RPDs $<20$ percent). Three constituents had median RPDs $>20$ percent: dissolved ammonia (median $=25.2$ percent; $n=5$ ), fecal coliform (median $=28.6$ percent; $n=13$ ), and dissolved iron 
(median=33.5 percent; $n=16$ ). RPDs $>20$ percent generally were due to low concentrations near the laboratory reporting level. Data for all analytes met the QA/QC objectives for this report.

Absolute value logarithmic difference (AVLD) was used to estimate differences in phytoplankton and cyanobacterial abundance, in cells per milliliter, between concurrent replicate pairs (Graham and others, 2017). AVLD was used because $\mathrm{RPD}$ is sensitive to rare taxa found in one of the samples and not the other. AVLD was calculated using the following equation:

$$
A V L D=\left|\log _{10} A-\log _{10} B\right|
$$

where

$A$ and $B \quad$ are abundance (cells per milliliter) in each

replicate pair (Francy and others, 2015).

Replicate pairs with AVLDs $<1$ differed by less than an order of magnitude; replicate pairs with AVLDs $>1$ varied by an order of magnitude or more.

The AVLDs for phytoplankton at the Wamego and De Soto sites ranged from 0 to 0.26 (median $=0.12 ; n=15$ ). The AVLDs for cyanobacterial abundance ranged from 0 to 3.1 (median=0.82; $n=15$ ). Fifty-three percent of the replicate pairs of cyanobacterial abundance had AVLDs of $<1$. Replicate pairs of cyanobacterial abundance with AVLDs $>1$ occurred when cyanobacteria were rare and accounted for $<7$ percent of the total phytoplankton abundance. Variability among replicate pairs of cyanobacterial abundance was less when cyanobacteria accounted for a larger portion of the total phytoplankton abundance. Phytoplankton and cyanobacteria data met QA/ QC objectives when the influence of rare taxa was taken into consideration.

\section{Data Analysis}

Reservoir contributions to Kansas River streamflow were estimated using the USGS streamgage network in the lower Kansas River Basin. The percentages of flow at the Wamego and De Soto sites contributed by reservoir outflows from Milford Lake, Tuttle Creek Lake, Perry Lake, and Clinton Lake were calculated as described in Graham and others (2012). The estimated contribution from each reservoir was calculated for each day during January 2012 through December 2016. Dynamic streamflow conditions complicate calculations of the percentage of flow contributed by reservoir outflows and estimated contributions are most accurate when streamflow conditions are stable. Streamflows were only stable for 393 days during January 2012 through December 2016. Although streamflow conditions were not stable on most dates, estimated reservoir contributions to streamflow were calculated for the entire study period to characterize relative patterns across seasons, years, and streamflow conditions. Reservoir contributions to streamflow in this analysis should be considered general estimates.
Ordinary least-squares analysis (Helsel and Hirsch, 2002) was used to develop regression models between sensormeasured fChl and laboratory-measured $\mathrm{Chl}$ concentrations. Because the relation between $\mathrm{fChl}$ and $\mathrm{Chl}$ is sensor and site dependent, separate models were developed for the YSI 6025 and EXO fChl sensors at the Wamego and De Soto sites. All sensors and sites had strong linear associations between fChl and $\mathrm{Chl}$, and fChl explained between 74 and 88 percent of the variance in $\mathrm{Chl}$, as indicated by the adjusted $R^{2}$ (appendixes 1 through 4). Kansas River chlorophyll concentrations at the Wamego and De Soto sites during July 2012 through September 2016 were estimated by using the fChl data collected by continuous monitors and the regression models developed using fChl and laboratory-measured $\mathrm{Chl}$ concentrations. Details of the regression models used to estimate chlorophyll concentrations are presented in appendixes 1 through 4. Regression-estimated chlorophyll concentrations were used to describe spatial and temporal patterns in the Kansas River during the study period.

Water-quality conditions in the Kansas River were described by site and season using discretely collected and continuously measured water-quality data. Seasons were defined as winter (January-March), spring (April-June), summer (July-September), and fall (October-December). Nondetections, or censored values reported as less than the laboratory reporting limit, were substituted with a value one-half of the minimum reporting limit for all analyses. Small sample sizes ( $<50$ observations) prevented the use of the commonly accepted maximum likelihood estimation approach when calculating means of constituents that contained censored values during a given season of a given year $(n=2-8$ in most cases). Additionally, the maximum likelihood estimation approach does not return estimations for individual censored values that could then be used to describe data on a seasonal or annual basis, but instead returns an estimation of the mean value using an assumed distribution based on the censored and noncensored data (Helsel, 2005).

Nonparametric Spearman rank-correlation analysis (Helsel and Hirsch, 2002) was used to determine monotonic relations between streamflow, water-quality conditions, and algal indicators (chlorophyll, algal abundance, cyanotoxins, and taste-and-odor compounds). Spearman rank-correlation coefficients (rho values; $R_{s}$ ) were considered significant when $p$-values were $<0.01$. Mann-Whitney rank sum tests (Helsel and Hirsch, 2002) were used to determine differences in environmental conditions when microcystin, geosmin, or MIB occurred above concentrations of $0.3 \mu \mathrm{g} / \mathrm{L}, 5 \mathrm{ng} / \mathrm{L}$, or $2 \mathrm{ng} / \mathrm{L}$, respectively. These concentrations were selected based on values relevant to drinking-water treatment and were exceeded frequently enough to allow the development of statistically valid models (Helsel and Hirsch, 2002; Taylor and others, 2005; U.S. Environmental Protection Agency, 2015). MannWhitney rank sum test statistics were considered significant when $p$-values were $<0.05$.

Previously published models were used to estimate the probability of cyanobacteria, microcystin, and geosmin 
occurrence above relevant thresholds on the basis of continuous water-quality data at the Wamego and De Soto sites (Foster and Graham, 2016). The models developed by Foster and Graham (2016) were considered suitable for estimating the probability of occurrence if they accurately classified at least 65 percent of the sample data, including the highest measured concentrations for a given constituent (Foster and Graham, 2016). After the best models were selected, the threshold probability for positive classification (TPPC) for each individual model was adjusted to maximize the number of samples classified as positive to make the model more conservative (more likely to give a false positive than a false negative) by guarding more strongly against false negatives (Foster and Graham, 2016). Models were developed using discrete water-quality and continuous-sensor data collected during July 2012 through June 2015 (Foster and Graham, 2016) and then evaluated using data collected during July 2015 through September 2016. Model performance was evaluated by comparing continuously estimated probability of occurrence to measured concentrations and placing data into one of four categories: positive response predicted as positive (true positive; model sensitivity), reference response predicted as reference (true negative; model specificity), positive response predicted as reference (false negative), and reference response predicted as positive (false positive). Model performance was considered good if at least 65 percent of the sample data were accurately classified, including the highest measured concentrations for a given constituent.

\section{Streamflow Conditions}

The structure and function of riverine ecosystems are largely affected by streamflow (Poff and others, 1997; Poff and Zimmerman, 2010; Archfield and others, 2014). Reservoirs in the Kansas River Basin control streamflow in about 85 percent of the drainage area and are operated for flood control and to maintain streamflows during low-flow conditions (Perry, 1994). Typically, reservoirs change downstream streamflow regimes by reducing the magnitude of peak flows and increasing the magnitude of low flows (Williams and Wolman, 1984). Reservoirs also affect downstream water quality by acting as sinks and sources for nutrients, sediments, and other compounds (Thornton and others, 1990).

Mean streamflow at the upstream Wamego site was about 34 percent lower than streamflow at the downstream De Soto site across all years and seasons during the study period. During 2012 through 2016, mean streamflows at both sites were highest during spring, and lowest during winter (table 1). Kansas was generally in a drought status during 2012 through 2014 (The National Drought Mitigation Center, 2018), and streamflow data reflected these conditions. Mean annual streamflows during 2012 through 2014 at the Wamego and De Soto sites were 55 to 69 percent lower than mean annual streamflows during 2015 and 2016 (table 1). Summer 2012 through winter 2013 had the lowest mean seasonal streamflows during the study period. Flows during 2015 and 2016 had a marked increase compared to previous years and included the largest flows observed during the study period.

During 2012 and 2013, streamflows at both sites in the Kansas River were below the study period average (figs. $3 A, B$ ). Streamflows during 2014 also were below average, except at a probability of exceedance of 70 percent and higher. At $<50$ percent probability of exceedance, 2015 and 2016 had higher streamflows than the study period average, likely due to storm events delivering episodic flows, rather than extended reservoir releases. In both analyses (summary statistics and duration curves), streamflows during 2012 through 2014 follow patterns expected during a period of drought, and patterns in 2015 and 2016 are indicative of nondrought streamflows.

Reservoirs contributed more than one-half of daily streamflow 49 percent or more of the time annually at the Wamego site during 2012 through 2016 (annual average=71 percent) (fig. $4 A$ ). At the De Soto site, reservoirs contributed more than one-half of daily streamflow between 36 and 62 percent of the time annually during 2012 through 2016 (annual average $=45$ percent) (fig. $4 B$ ). The Wamego site typically had a greater percentage of flow from upstream reservoirs than the De Soto site, despite De Soto having more contributing reservoirs (figs. $4 A, B$ ).

Seasonally, fall and winter had the greatest number of days where reservoirs contributed more than one-half of the total flow at the Wamego and De Soto sites, and spring and summer had the least number of days (figs. $4 A, B$ ). Seasonal reservoir contribution to total streamflow follows precipitation patterns typically experienced in the study area, with wet springs and early summers, and dry late summers into winters. During the fall season, reservoir elevations are sometimes lowered for the creation of wetland habitats for migratory birds and to reduce potential ice impacts on dams, which results in increased reservoir outflows. The percentage of days with more than 50 percent reservoir contributions to total streamflow at the Wamego and De Soto sites seasonally was 86 and 43 percent, respectively, during winter; 67 and 33 percent during spring; 58 and 40 percent during summer; and 75 and 65 percent during fall.

The highest annual streamflow contributions from reservoirs in the Kansas River were observed in 2012, when reservoirs contributed more than 50 percent to total streamflow 87 percent and 62 percent of the time at the Wamego and De Soto sites, respectively. The lowest annual reservoir contributions were observed in 2016, when 49 percent and 36 percent of the time reservoirs contributed more than 50 percent of total streamflow at the Wamego and De Soto sites, respectively. In 2016, Tuttle Creek Lake contributed more than one-half of the total streamflow at least 27 percent of the time at the Wamego site and 5 percent of the time at the De Soto site. No other reservoir annually contributed more than one-half of total streamflow at either site more than 3 percent of the time (for example, Milford Lake at the Wamego site during 2012 and 2015) (figs. $4 A, B$ ). 
Table 1. Streamflow summary statistics for the Kansas River at Wamego, Kansas, and Kansas River at De Soto, Kansas, streamgages (U.S. Geological Survey stations 06887500 and 06892350, respectively) during January 2012 through December 2016.

[min, minimum; max, maximum]

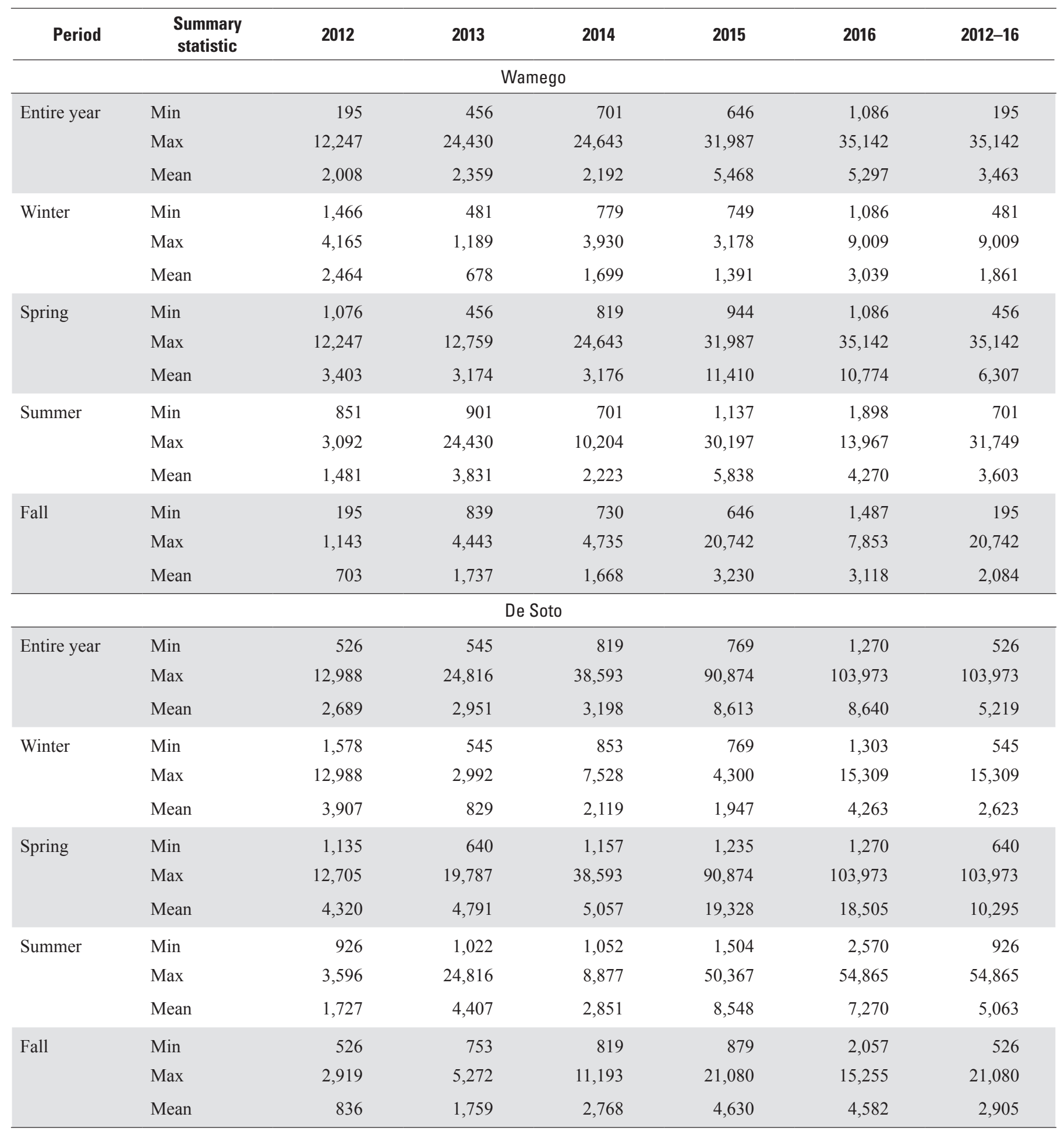




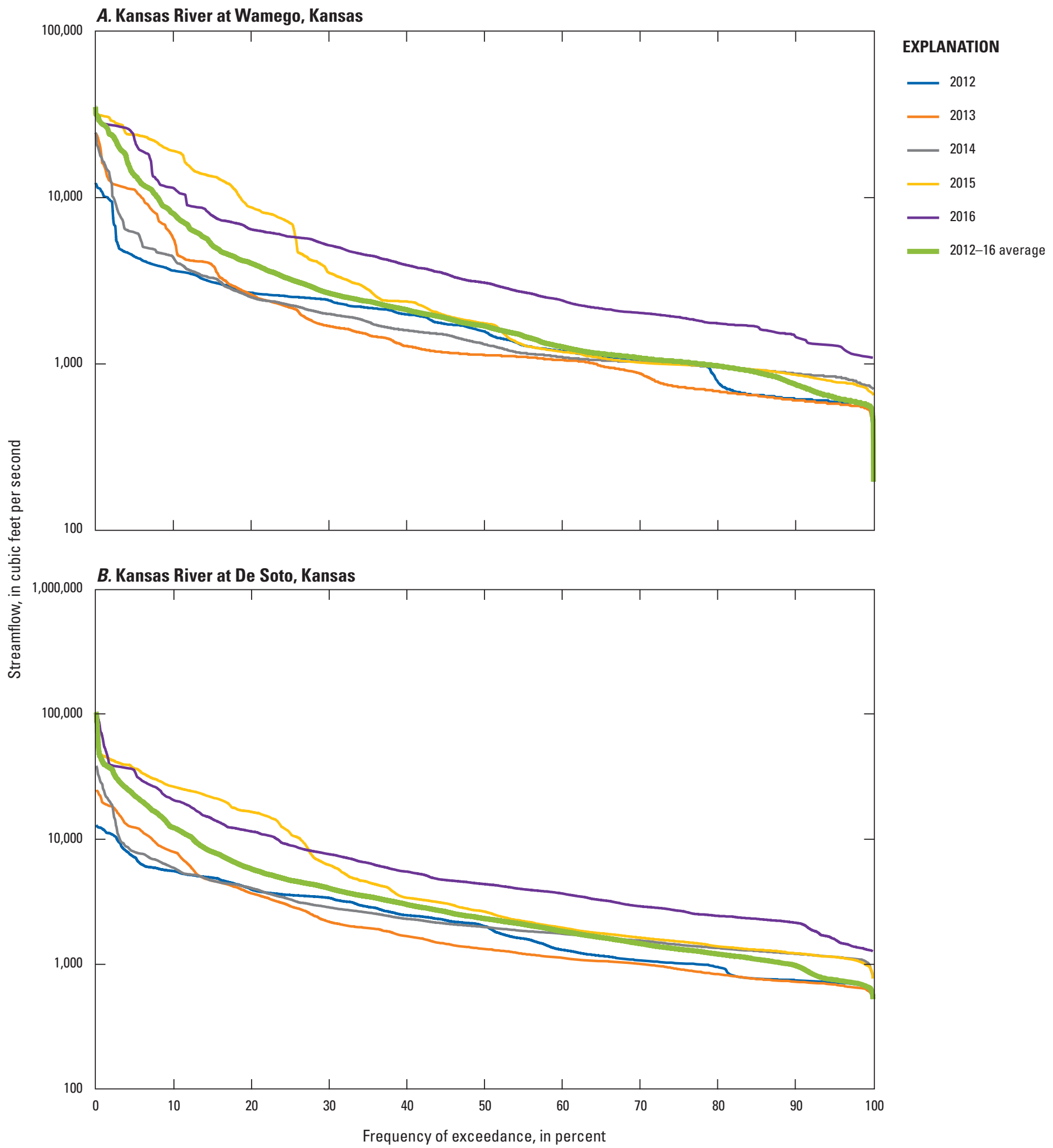

Figure 3. Duration curves for overall and annual streamflows during January 2012 through December 2016. $A$, Kansas River at the Kansas River at Wamego, Kansas (U.S. Geological Survey station 06887500). B, Kansas River at De Soto, Kansas (U.S. Geological Survey station 06892350). 


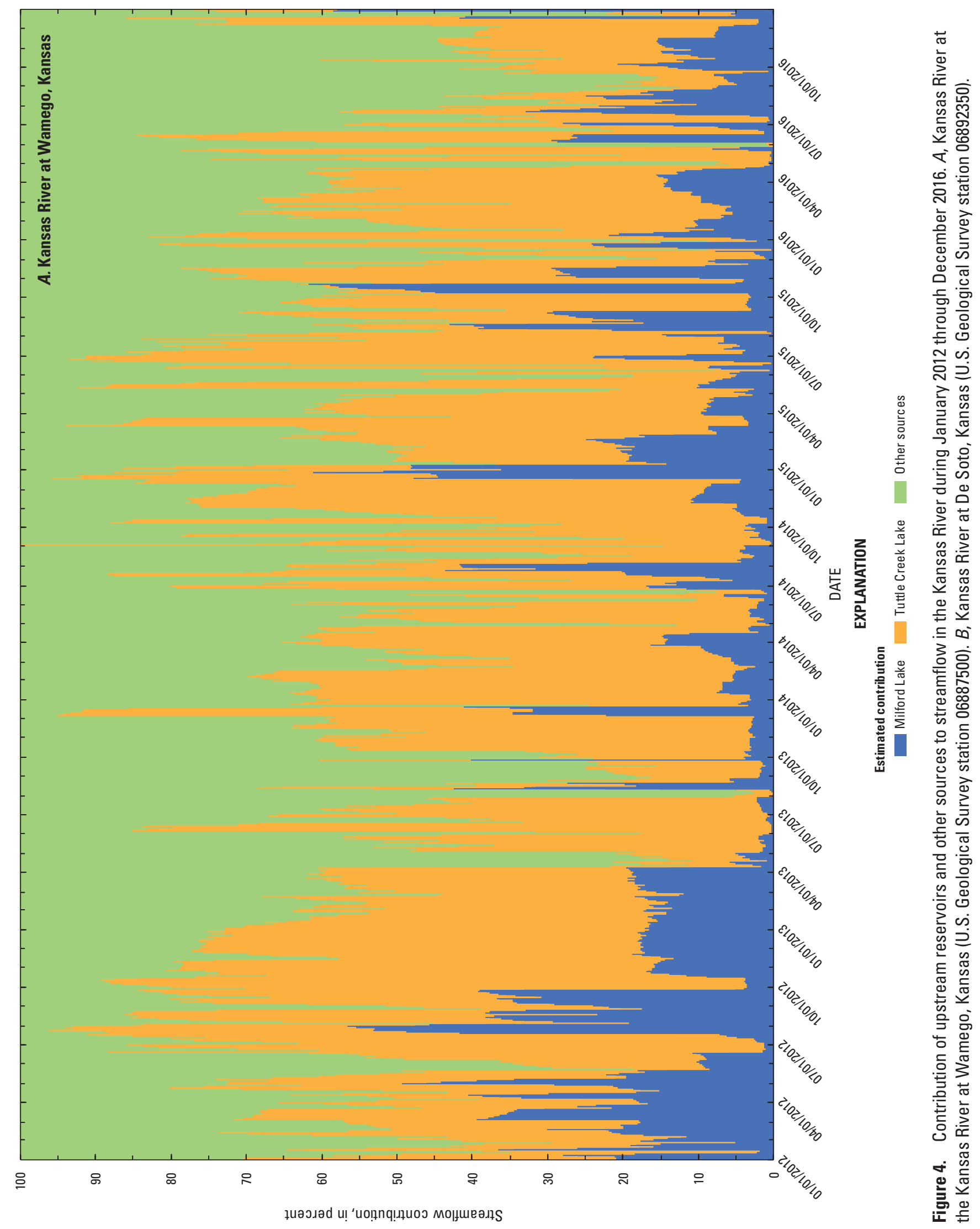




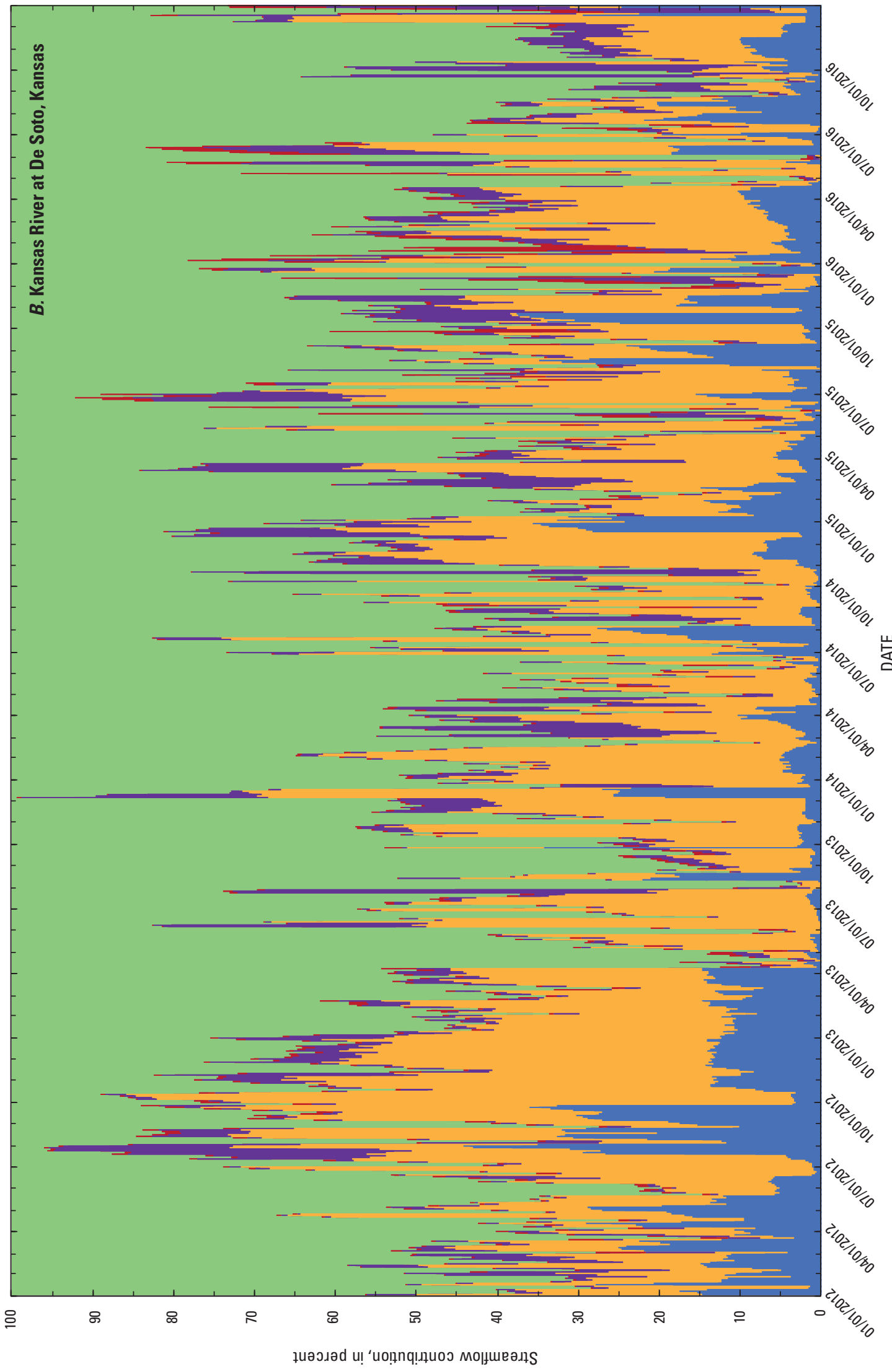

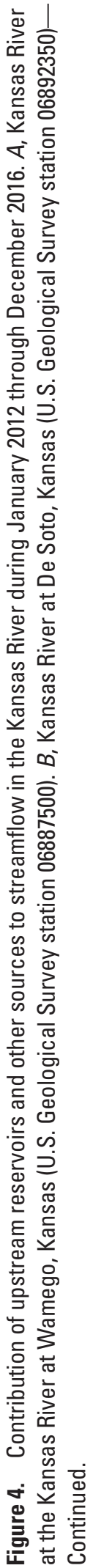




\section{Select Water-Quality Conditions}

The USGS has collected continuous (15-minute intervals) and discrete water-quality data at two sites (Wamego and De Soto, fig. 1) on the Kansas River since July 2012. Continuous water-quality data collected at the upstream Wamego site during August 2012 through September 2016 and the downstream De Soto site during July 2012 through September 2016 were used to describe water-quality conditions in the Kansas River. Continuous water-quality data included water temperature, $\mathrm{pH}$, dissolved oxygen, turbidity, specific conductance, and fChl. Discrete water-quality samples were collected at both sites during July 2012 through September 2016. Samples were collected approximately bimonthly during May through October and monthly during November through April. Discrete samples were analyzed for SSC, dissolved solids and major ions, nutrients (nitrogen and phosphorus species), trace elements, and indicator and actinomycetes bacteria.

\section{Water Temperature, pH, and Dissolved Oxygen}

Water temperature affects the solubility of chemicals in water and biological activity. Water temperatures in the Kansas River ranged from -0.8 to 34 degrees Celsius $\left({ }^{\circ} \mathrm{C}\right)$. Overall differences in water temperature between the Wamego and De Soto sites were relatively small (about 2 percent on average; table 2 at the back of this report; fig. 5A). Summer 2012 average water temperatures seem to be 2 to $4{ }^{\circ} \mathrm{C}$ lower than other summers, possibly because only a partial season of data was collected during the first year of the study. Water temperatures were warmest in summer during low streamflows and coldest during winter. Spring, summer, and fall seasonal mean water temperatures were generally similar across years and typically varied by about $2{ }^{\circ} \mathrm{C}$ or less. Mean winter water temperature in 2016 was notably warmer than other years, with mean water temperatures about 3 to $4{ }^{\circ} \mathrm{C}$ higher than observed in 2014 (table 2).

$\mathrm{pH}$ is a measure of the effective hydrogen ion concentration and is often used to evaluate chemical and biological reactions in water (Hem, 1992). Kansas aquatic life support criteria require that $\mathrm{pH}$ in streams not measure less than 6.5 or more than 8.5 standard units (Kansas Department of Health and Environment, 2015). Measured $\mathrm{pH}$ was never lower than 6.5 at the Wamego and De Soto sites but exceeded the maximum criterion of 8.5 about 33 percent of the time at the Wamego site and 39 percent of the time at the De Soto site (fig. 5B). Exceedances were observed across all seasons and years but occurred more often during low-flow conditions in 2012 through 2014. At the Wamego site, 76 percent of $\mathrm{pH}$ values higher than 8.5 were observed during 2012 through 2014, and at the De Soto site, 64 percent were observed during 2012 through 2014. Exceedances often extended for periods of days or weeks and likely were caused by increased algal photosynthesis during low-flow conditions when biological processes may have a substantial influence on water chemistry (Wetzel,
2001). Patterns in exceedance of the maximum $\mathrm{pH}$ criterion during 2012 through 2016 were similar to those observed in the Kansas River during 2000 through 2003 (Rasmussen and others, 2005).

Dissolved oxygen is an important factor for the survival of aquatic organisms, and concentrations in surface water are related primarily to photosynthesis, respiration, atmospheric reaeration, and water temperature (Wilde, 2008). Kansas aquatic life support criteria require that dissolved oxygen concentrations are not $<5.0$ milligrams per liter $(\mathrm{mg} / \mathrm{L}$ ) (Kansas Department of Health and Environment, 2015). Dissolved oxygen concentrations were lowest in summer, concurrent with seasonal lows in streamflow and highs in water temperature, and highest in winter during seasonal lows in water temperature (table 2, fig. 5C). Less than 1 percent of dissolved oxygen values during the study period were $<5.0 \mathrm{mg} / \mathrm{L}(0.22$ and 0.03 percent at the Wamego and De Soto sites, respectively). At the Wamego site, low dissolved oxygen concentrations were observed over a 5-day period during a summer 2013 runoff event and at night over a 4-day period during low-flow conditions $\left(<1,000\right.$ cubic feet per second $\left.\left[\mathrm{ft}^{3} / \mathrm{s}\right]\right)$ in summer 2014. At the De Soto site, low dissolved oxygen concentrations were observed for a 3-hour period during a spring 2013 runoff event and once overnight in summer 2014 during low-flow conditions (about 1,100 ft $3 / \mathrm{s}$ ).

\section{Turbidity and Suspended Sediment}

Suspended sediments in streams typically are from erosion and subsequent transport of land-surface soils and channel banks. Increased suspended sediment in streams decreases light penetration and photosynthesis, smothers benthic habitats, and interferes with feeding activities (Wetzel, 2001). In addition, suspended particulates promote sorption of nutrients, organic compounds, and other potential contaminants. Turbidity often is used as a surrogate measure for suspended sediment, and in the Kansas River there is a strong positive association between turbidity and SSC (Rasmussen and others, 2005; Foster and Graham, 2016).

Although turbidities tended to be higher at the De Soto site than the Wamego site, overall differences between the sites were small and occurred at the lower and upper ends of the observed range (table 2, fig. 5D). On average, turbidity was about 10 percent higher at the De Soto site than the Wamego site. The EPA guidelines for turbidity (based on reference conditions) list 19.5 FNU for level III ecoregion 28 (Flint Hills) streams, which includes the Kansas River at Wamego, Kans. streamgage (U.S. Environmental Protection Agency, 2001). The EPA guidelines for turbidity (based on reference conditions) list 15.5 FNU for level III ecoregion 40 (central irregular plains) streams, which includes the Kansas River at De Soto, Kans., streamgage (U.S. Environmental Protection Agency, 2000). Guidelines are nonenforceable criteria developed for the protection of water quality, aquatic life, and human health. Turbidities exceeded 19.5 FNU about 

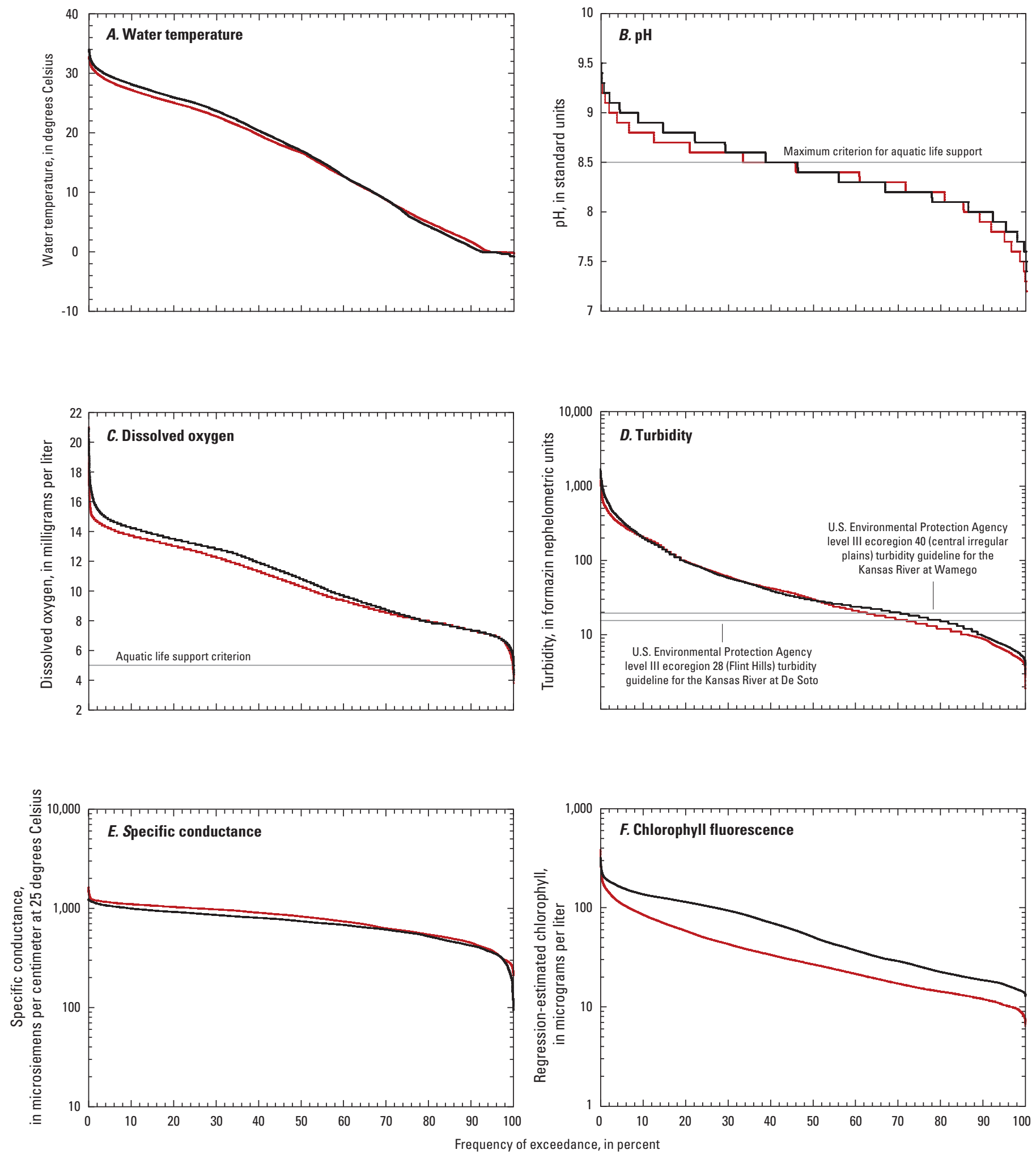

EXPLANATION

Kansas River at Wamego, Kansas

Kansas River at De Soto, Kansas

Figure 5. Duration curves for continuously measured water-quality constituents at the Kansas River at Wamego, Kansas, and Kansas River at De Soto, Kansas, streamgages (U.S. Geological Survey stations 06887500 and 06892350 , respectively) during July 2012 through September 2016. $A$, water temperature; $B, \mathrm{pH} ; C$, dissolved oxygen; $D$, turbidity; $E$, specific conductance; and $F$, chlorophyll fluorescence. 
63 percent of the time at the Wamego site and 70 percent of the time at De Soto site. The 15.5 FNU criterion was exceeded about 72 and 80 percent of the time at the Wamego and De Soto sites, respectively (fig. $5 D$ ).

At both sites, seasonal mean turbidity values were lowest in winter and highest in spring and summer (table 2). Winter mean turbidity was 83 to 89 percent lower than spring and summer mean turbidity values. Seasonal mean turbidities at both sites generally increased throughout the study period (table 2). For example, spring mean turbidities in 2015 and 2016 were 17 to 133 percent higher than mean spring turbidities in 2013 and 2014. Transport of suspended sediments generally increases with increased streamflows. The observed seasonal and interannual patterns in turbidity values were associated with seasonal and annual changes in streamflows. Seasonal minima in streamflow and turbidity occur during winter, and streamflows and turbidities increased between 2012 and 2016 (tables 1, 2).

Patterns in SSC based on discrete samples collected during 2012 through 2016 match patterns in turbidity. On average, SSCs were about 15 percent higher at the De Soto site $(331 \mathrm{mg} / \mathrm{L})$ than the Wamego site $(288 \mathrm{mg} / \mathrm{L})$ (table 2$)$. Seasonal mean SSCs were highest in spring and lowest in winter. Spring mean SSCs were about 57 to 579 percent higher than any other season. Patterns in seasonal mean SSCs were not as evident as observed for turbidity, but spring mean SSCs in 2016 were 165 to 341 percent higher than mean spring SSCs in 2013 (table 2).

\section{Dissolved Solids and Major Ions}

Specific conductance is a measure of water's ability to conduct an electrical current and is related to the concentration of ionized materials in water (Hem, 1992). Major constituents of dissolved solids generally are calcium, magnesium, sodium, potassium, bicarbonate, carbonate, sulfate, and chloride ions (Hem, 1992). Because specific conductance is a measure of ionized materials in water, there is a strong positive association between specific conductance, dissolved solids, and major ions in the Kansas River (Rasmussen and others, 2005; Foster and Graham, 2016). Specific conductance, dissolved solids, and major ions in surface water are influenced by watershed geology and soils and are typically higher during low streamflows. In addition, road salt may substantially increase specific conductance and associated ions, particularly chloride, in streams during winter months (Corsi and others, 2010). Precipitation and runoff events often decrease specific conductance and concentrations of dissolved solids and major ions in surface waters.

Specific conductance was consistently higher at the Wamego site than the De Soto site, but overall differences between sites were relatively small (table 2, fig. $5 E$ ). On average, specific conductance was about 10 percent higher at the Wamego site than the De Soto site. At both sites, seasonal mean specific conductance values were 12 to 50 percent higher during winter than any other season, likely because of the combined influence of seasonal lows in streamflow and road salt applications. Mean annual specific conductance values at both sites decreased each year between 2012 and 2016 (table 2). The decrease across years likely can be attributed to the increase in streamflows between 2012 and 2016 (table 1).

Spatial and temporal patterns in dissolved solids and major ion concentrations from discrete samples matched patterns in continuous specific conductance. On average, constituent concentrations were about 6 to 25 percent higher at the Wamego site than De Soto site (table 2). Differences in calcium, magnesium, and bicarbonate were lowest (6 to 7 percent difference) between the two sites and differences in sodium and chloride were highest (20 to 25 percent difference). With the exception of potassium, seasonal mean values of all measured constituents were 5 to 105 percent higher during winter than any other season. Potassium concentrations varied by $<2 \mathrm{mg} / \mathrm{L}$ ( 1 to 26 percent difference) across seasons (table 2). Sodium and chloride had the highest differences in seasonal mean concentrations. As observed for specific conductance, mean annual concentrations of dissolved solids and major ions at both sites generally decreased between 2012 and 2016 (table 2).

The EPA has established nonenforceable secondary drinking-water regulations (SDWR) for dissolved solids $(500 \mathrm{mg} / \mathrm{L})$, sulfate $(250 \mathrm{mg} / \mathrm{L})$, and chloride $(250 \mathrm{mg} / \mathrm{L}$, with an advisory level of $20 \mathrm{mg} / \mathrm{L}$ for people on low sodium diets; U.S. Environmental Protection Agency, 2009). These regulations and the advisory level are for finished drinking water and are not directly applicable to observed environmental concentrations but do provide a benchmark for comparison. Discrete sample data were compared to the regulations and advisory level. Dissolved solids concentrations exceeded $500 \mathrm{mg} / \mathrm{L}$ in 46 and 34 percent of discrete samples collected at the Wamego and De Soto sites, respectively, during 2012 through 2016 (Williams and others, 2018). In addition, continuous estimates of dissolved solids, sulfate, chloride, and sodium were calculated from regression models that used specific conductance as an explanatory variable (Foster and Graham, 2016). Continuous estimates for all constituents with regression models developed by Foster and Graham (2016) are available on the USGS National Real-Time Water Quality website (https://nrtwq.usgs.gov/). Based on continuous estimates, dissolved solids concentrations during 2012 through 2016 exceeded $500 \mathrm{mg} / \mathrm{L}$ about 52 percent of the time at the Wamego site and 36 percent of the time at the De Soto site. Exceedances for dissolved solids were observed across all seasons and years but were observed most frequently during fall and winter. Sulfate concentrations based on discrete samples and continuous estimates never exceeded $250 \mathrm{mg} / \mathrm{L}$ at either site during 2012 through 2016 (Williams and others, 2018) (table 2). Sodium concentrations exceeded $20 \mathrm{mg} / \mathrm{L}$ in most discrete samples collected at the Wamego (96 percent) and De Soto (87 percent) sites during 2012 through 2016 (Williams and others, 2018) (table 2). Based on continuous estimates, sodium concentrations almost always exceeded 
$20 \mathrm{mg} / \mathrm{L}$ at both sites (96 and 94 percent at the Wamego and De Soto sites, respectively) (Williams and others, 2018).

Chloride has an established SDWR as well as criteria for protection of aquatic life (U.S. Environmental Protection Agency, 1986, 2009). The EPA SDWR is $250 \mathrm{mg} / \mathrm{L}$, the acute exposure criterion is $860 \mathrm{mg} / \mathrm{L}$, and the chronic exposure criterion is $230 \mathrm{mg} / \mathrm{L}$. Based on discrete samples, chloride concentrations never exceeded $230 \mathrm{mg} / \mathrm{L}$ at either site during 2012 through 2016. Continuous estimates of chloride concentrations indicated that concentrations never exceeded the acute exposure criterion at either site, but the SDWR and chronic exposure criterion were exceeded at the Wamego site, though only rarely $(<1$ percent of the time). Most exceedances at the Wamego site occurred during low flows $\left(<2,300 \mathrm{ft}^{3} / \mathrm{s}\right)$ in the spring.

\section{Nutrients}

Nutrients, particularly nitrogen and phosphorus, are considered leading causes of water-quality impairment in Kansas and throughout the Nation (Kansas Department of Health and Environment, 2004; U.S. Environmental Protection Agency, 2009). Nutrients are essential for the growth of all organisms; however, excessive concentrations in aquatic environments may cause adverse human health and ecological effects. Excess nutrients are associated with eutrophication and can result in algal blooms, decreased dissolved oxygen, taste-andodor issues, increased turbidity, and depletion of flora and fauna (Wetzel, 2001).

In 2000, the EPA recommended ecoregion-based nutrient criteria for streams. Reference conditions for total nitrogen (TN) and total phosphorus (TP) in level III ecoregion 28 (Flint Hills) streams, which includes the Kansas River at Wamego, Kans., streamgage, are defined as 0.58 and 0.06 $\mathrm{mg} / \mathrm{L}$, respectively (U.S. Environmental Protection Agency, 2001). Reference conditions for TN and TP in level III ecoregion 40 (central irregular plains) streams, which includes the Kansas River at De Soto, Kans., streamgage, are defined as 0.855 and $0.0925 \mathrm{mg} / \mathrm{L}$, respectively (U.S. Environmental Protection Agency, 2001). These criteria were intended as a preliminary attempt to describe the nutrient concentrations that would protect designated uses and mitigate the effects of nutrient enrichment and are not used for regulatory purposes. The Kansas Department of Health and Environment (KDHE) uses a median TP concentration of $0.201 \mathrm{mg} / \mathrm{L}$ to determine if a stream site should be on the Clean Water Act Section 303(d) list of impaired waters for phosphorus (Kansas Department of Health and Environment, 2004). All TN and TP sample concentrations at the Wamego and De Soto sites exceeded ecoregion criteria for reference conditions. During a 2000 through 2003 study, Rasmussen and others (2005) also determined that all TN and TP sample concentrations exceeded ecoregion criteria in the Kansas River. TP sample concentrations at both sites almost always exceeded the KDHE value for 303(d) listing (table 2). About 95 percent of TP samples collected at the Wamego $(n=79)$ and De Soto $(n=89)$ sites had concentrations higher than $0.201 \mathrm{mg} / \mathrm{L}$ (Williams and others, 2018). TP concentrations $<0.201 \mathrm{mg} / \mathrm{L}$ were observed during low streamflows ( $<800$ and $1,400 \mathrm{ft}^{3} / \mathrm{s}$ at the Wamego and De Soto sites, respectively) and low turbidities ( $<23$ and 14 at the Wamego and De Soto sites, respectively) in December through April.

Inorganic nitrogen compounds, such as nitrate and ammonia, may be toxic to aquatic organisms at high concentrations. In addition, high nitrate concentrations in drinking water can impair the oxygen-carrying capacity of hemoglobin in humans (Camago and Álonso, 2006).

The EPA has established enforceable primary drinkingwater regulations (PDWR) for nitrate $(10 \mathrm{mg} / \mathrm{L})$ and nitrite $(1 \mathrm{mg} / \mathrm{L})$ (U.S. Environmental Protection Agency, 2009). These regulations are for finished drinking water and are not directly applicable to observed environmental concentrations but do provide a benchmark for comparison. Nitrate and nitrite concentrations in discrete samples never exceeded 3.0 and $0.24 \mathrm{mg} / \mathrm{L}$, respectively, at the Wamego and De Soto sites (Williams and others, 2018).

The EPA has established acute and chronic ammonia criteria for the protection of aquatic life (U.S. Environmental Protection Agency, 2013). The toxicity of ammonia is dependent on $\mathrm{pH}$ and water temperature; therefore, criteria vary with conditions of these water-quality parameters. At a $\mathrm{pH}$ of 7.0 and a water temperature of $20^{\circ} \mathrm{C}$, the acute criterion for total ammonia nitrogen is $17 \mathrm{mg} / \mathrm{L}$ and the chronic criterion is $1.9 \mathrm{mg} / \mathrm{L}$. Ammonia was above the laboratory reporting level $(0.01 \mathrm{mg} / \mathrm{L})$ in 42 percent of samples collected at each site. Concentrations never exceeded $0.25 \mathrm{mg} / \mathrm{L}$ in samples at either site on the Kansas River during 2012 through 2016 (Williams and others, 2018).

Overall differences in TN and TP concentrations between the Wamego and De Soto sites were small (table 2). Mean TN and TP concentrations were 4 and 7 percent higher at the De Soto site than the Wamego site, respectively. Seasonal mean nutrient concentrations were highest in spring and lowest during fall and winter. Spring mean TN and TP concentrations were 3 to 114 percent higher than any other season. Mean annual total nutrient concentrations at both sites generally increased each year between 2012 and 2016 (table 2). Transport of nutrients increased with increased streamflows, and TN and TP concentrations in the Kansas River were positively correlated with streamflow (all $R_{s}>0.67$, all $p<0.01$ ). The observed seasonal and interannual patterns in total nutrient concentrations were associated with seasonal and annual changes in streamflows. Seasonal maxima in streamflow occur during spring, and streamflow increased between 2012 and 2016 (tables 1, 2).

Inorganic nutrient concentrations were positively correlated with streamflow, though correlations were not as strong as for total nutrients. Nitrate plus nitrite was more strongly correlated with streamflow (all $R_{\mathrm{s}}>0.58$, all $p<0.01$ ) than orthophosphorus (all $R_{s}<0.43$, all $p<0.01$ ). On average, nitrate plus nitrite and orthophosphorus concentrations were about 
36 to 41 percent higher at the Wamego site than the De Soto site. Seasonal mean nitrate plus nitrite concentrations at both sites were highest in spring (table 2). In contrast, orthophosphorus concentrations were 36 to 41 percent lower in spring than other seasons at the De Soto site and about 20 percent lower in spring and winter than other seasons at the Wamego site. As observed for total nutrients, mean annual inorganic nutrient concentrations at both sites generally increased each year between 2012 and 2016 (table 2).

\section{Trace Elements}

Trace elements are typically present in low concentrations in stream water and are influenced by watershed geology (Hem, 1992). Of the trace elements measured as part of this study, three (arsenic, fluoride, and selenium) have enforceable PDWR. These regulations are for finished drinking water and are not directly applicable to observed environmental concentrations but do provide a benchmark for comparison. The PDWR for arsenic, fluoride, and selenium are 0.010, 4.0, and $0.05 \mathrm{mg} / \mathrm{L}$, respectively (U.S. Environmental Protection Agency, 2009). Sampled arsenic (maximum $0.007 \mathrm{mg} / \mathrm{L}$ ), fluoride (maximum $0.38 \mathrm{mg} / \mathrm{L}$ ), and selenium (maximum 0.002 $\mathrm{mg} / \mathrm{L}$ ) concentrations never exceeded the regulatory criteria in the Kansas River during 2012 through 2016.

\section{Indicator and Actinomycetes Bacteria}

Fecal coliform, E. coli, and enterococci are the three most common types of bacteria used as indicators of pathogens in surface water. Indicator bacteria are used to evaluate the sanitary quality of water and its use as a public water supply and for recreational activities (Eaton and others, 2005). KDHE uses seasonal criteria for $E$. coli bacteria to protect public health during primary (swimming) and secondary (wading, boating, and fishing) contact recreation (Kansas Department of Health and Environment, 2015). Because the Kansas River is publicly accessible, it supports both types of recreation. Criteria for primary contact recreation are defined as geometric means for two seasons: April through October (spring/summer) and November through March (fall/winter). The criterion for primary contact recreation is a geometric mean of 262 colony forming units per $100 \mathrm{~mL}$ (CFUs/100 mL) during spring/ summer. About 20 percent of samples collected at the Wamego and De Soto sites during July 2012 through September 2016 exceeded 262 CFUs/100 mL. The criterion for primary contact recreation during fall/winter and secondary contact recreation is a geometric mean of 2,358 CFUs $/ 100 \mathrm{~mL}$. About 2 and 6 percent of samples collected at the Wamego and De Soto sites exceeded 2,358 CFUs/mL, respectively. With the exception of sample exceedances $(>20,000 \mathrm{CFUs} / 100 \mathrm{~mL})$ at both sites during one event in December 2015, all exceedances occurred during spring/summer. Exceedances typically were associated with rainfall and runoff events.
Mean concentrations of indicator bacteria in the Kansas River were about 55 to 159 percent higher at the De Soto site than the Wamego site during 2012 through 2016 (table 2). Seasonal mean concentrations of $E$. coli and enterococci bacteria were substantially higher in spring than any other season (18 to 12,372 percent overall). Fecal coliform bacteria concentrations had similar variability during spring through fall, but were typically an order of magnitude or two lower in winter than in any other season (table 2). Mean annual indicator bacteria concentrations at both sites generally increased each year between 2012 and 2016 (table 2).

Bacteria in the actinomycetes group may produce the taste-and-odor compounds geosmin and MIB (Taylor and others, 2005). The actinomycetes bacteria typically are terrestrial organisms associated with soils and are washed into aquatic ecosystems during rainfall and runoff events (Zaitlin and others, 2003; Zaitlin and Watson, 2006). The highest observed actinomycetes concentration at the Wamego site $(21,000$ colonies per milliliter) was about 130 percent higher than the next highest concentration observed at the Wamego site $(9,000$ colonies per milliliter) and 50 percent higher than the highest concentration observed at the De Soto site $(14,000$ colonies per milliliter) (Williams and others, 2018) (table 2). The one high value at the Wamego site had a substantial influence on mean site, seasonal, and annual concentrations and was excluded from calculations of descriptive summary statistics. When the unusually high value was excluded from the dataset, patterns in actinomycetes bacteria were similar to indicator bacteria. Mean actinomycetes concentration was about 42 percent higher at the De Soto site than Wamego site (table 2). Seasonal mean actinomycetes concentrations were 55 to 87 percent lower during winter than any other season. Seasonal mean actinomycetes concentrations were highest during spring at the Wamego and De Soto sites, though this pattern was inconsistent across years. Mean annual actinomycetes concentrations varied across years and did not display clear patterns (table 2). Transport of actinomycetes bacteria typically increases with increased streamflows, and concentrations in the Kansas river were positively correlated with streamflow (all $R_{s}>0.58$, all $p<0.01$ ). Other factors, such as time since last rainfall and runoff event, soil temperatures, and temporal variability of actinomycetes communities in soils, likely also influence transport of actinomycetes bacteria in the Kansas River.

\section{Cyanobacteria, Cyanotoxins, and Taste-and-Odor Compounds}

In addition to commonly measured water-quality constituents, discrete water-quality samples collected at both sites during July 2012 through September 2016 were analyzed for cyanobacteria and associated compounds. Algal biomass, phytoplankton abundance and community composition, the cyanotoxins microcystin and cylindrospermopsin (July 2015 through September 2016 only), and the taste-and-odor 
compounds geosmin and MIB were analyzed in all routinely collected samples.

\section{Algal Biomass and Community Composition}

Chlorophyll is commonly used as an estimate of algal biomass because analysis is simpler and less time consuming than identifying, counting, and measuring algal cells (Hambrook Berkman and Canova, 2007). The sensor-measured fChl data at the Wamego and De Soto sites were corrected to laboratory-measured chlorophyll samples (appendixes 1 through 4) and used to describe spatial and temporal patterns in algal biomass in the Kansas River during July 2012 through September 2016. Sensor-measured chlorophyll concentrations were consistently higher at the De Soto site than the Wamego site during the study period (fig. $5 F$ ). Mean sensor-measured chlorophyll concentration was 74 percent higher at the De Soto site than the Wamego site (table 2). Seasonal mean sensor-measured chlorophyll concentrations were highest in spring and summer (the growing season) and lowest during winter. Winter sensor-measured chlorophyll concentrations were 26 to 72 percent lower than any other season. Mean annual sensor-measured chlorophyll concentrations varied less across years ( 6 to 24 percent during years with data collection across all seasons) than seasons, likely reflecting the influence of temperature on algal growth (Reynolds, 1984).

Dodds and others (1998) proposed a trophic classification system for rivers based on chlorophyll concentrations. Chlorophyll concentrations $<10 \mu \mathrm{g} / \mathrm{L}$ are indicative of oligotrophic (nutrient poor, low productivity) systems; concentrations between 10 and $30 \mu \mathrm{g} / \mathrm{L}$ are indicative of mesotrophic (moderate nutrient levels, intermediate productivity) systems; and concentrations $>30 \mu \mathrm{g} / \mathrm{L}$ are indicative of eutrophic (nutrient rich, high productivity) systems. Sensor-measured chlorophyll concentrations in the Kansas River were indicative of mesotrophic to eutrophic conditions (fig. $5 F$, table 2). Sensor-measured chlorophyll concentrations exceeded $10 \mu \mathrm{g} / \mathrm{L} 97$ percent of the time at the Wamego site and 100 percent of the time at the De Soto site. The $30 \mu \mathrm{g} / \mathrm{L}$ threshold was exceeded 45 percent of the time at the Wamego site and 68 percent of the time at the De Soto site.

Typically, algal biomass in aquatic ecosystems is highest during low streamflows when light and nutrients are abundant, though relations may be more complex in rivers because streamflow may far exceed algal growth rates and preclude accumulation of biomass (Søballe and Kimmel, 1987; Wetzel, 2001; Allan and Castillo, 2007). Based on discretely collected data, chlorophyll concentrations at the Wamego and De Soto sites were negatively correlated with streamflow (all $R_{s}<-0.44$, all $p<0.01$ ) and total and bioavailable (orthophorphorus and nitrate plus nitrite) nutrient concentrations (all $R_{s}<-0.36$, all $p<0.01)$. Chlorophyll concentrations also were negatively, but weakly, correlated with turbidity (an indicator of underwater light conditions) at the De Soto site $\left(R_{s}=-0.30, p<0.01\right)$, but there was no significant correlation at the Wamego site
$\left(R_{s}=-0.17, p=0.14\right)$. The negative association between chlorophyll and nutrients in the Kansas River likely is caused by the relatively strong positive association between nutrient concentrations and streamflows. Algal biomass at the De Soto site was always higher than at the Wamego site, despite the higher streamflows and lower bioavailable nutrient concentrations observed at the De Soto site. Higher algal biomass at the De Soto site likely was caused by algal growth during downstream transport without major losses due to grazing by aquatic organisms or other processes. Although nutrients are of importance for algal growth, downstream transport often makes the influence of nutrients and other processes on algal biomass difficult to discern (Allan and Castillo, 2007).

Total phytoplankton abundance in the Kansas River was strongly, and positively, correlated with chlorophyll concentrations (all $R_{s}>0.85$, all $p<0.01$ ). Spatial and temporal patterns in total phytoplankton abundance generally matched patterns in chlorophyll. Abundances were consistently higher at the De Soto site than the Wamego site and seasonal mean abundances were highest during summer and lowest in winter (table 2). Like chlorophyll, total phytoplankton abundances at the Wamego and De Soto sites were negatively, and relatively weakly, correlated with streamflow (all $R_{s}<-0.39$, all $p<0.01$ ) and nutrients (all $R_{s}<-0.27$, all $p<0.01$ ). Total phytoplankton abundance was negatively correlated with turbidity at the De Soto site $\left(R_{s}=-0.24, p=0.03\right)$, but the relation between total abundance and turbidity was not statistically significant at the Wamego site.

Reservoirs can substantially impact the phytoplankton community composition in rivers, and cyanobacteria and diatoms tend to persist farther downstream than other algal groups, perhaps due to differential trapping and settling (Reynolds, 1984; Allan and Castillo, 2007; Wehr and Sheath, 2003; Graham and others, 2012). Generally, diatoms dominate riverine phytoplankton communities, though cyanobacteria can also commonly be present (Allan and Castillo, 2007; Wehr and Sheath, 2003). Algal communities in the Kansas River typically were dominated ( $>50$ percent of total phytoplankton abundance) by diatoms (about 81 percent of samples overall, $n=165)$. In this study, cyanobacteria were of particular interest because of their potential for production of cyanotoxins and taste-and-odor compounds. Cyanobacteria were relatively common in the Kansas River, present in about 66 and 69 percent of samples collected at the Wamego $(n=82)$ and De Soto $(n=83)$ sites, respectively, during July 2012 through September 2016; however, cyanobacteria rarely dominated the algal community ( 4 and 7 percent of samples collected at the Wamego and De Soto sites, respectively).

Fourteen cyanobacterial genera that have the potential to produce cyanotoxins and taste-and-odor compounds were observed in the Kansas River during July 2012 through September 2016 (Graham and others, 2008; Meriluoto and others, 2017) (table 3). Most of these genera were rare, occurring in $<20$ percent of samples; however, Aphanizomenon, Dolichospermum (formerly Anabaena), and Raphidiopsis were present in 30, 27, and 21 percent of samples collected from the 
Table 3. Potential cyanotoxin and taste-and-odor producing cyanobacteria in the Kansas River during July 2012 through September 2016.

[MIB, 2-methylisoborneol; X, present; --, not applicable]

\begin{tabular}{|c|c|c|c|c|}
\hline \multirow{2}{*}{ Cyanobacterial genera } & \multicolumn{2}{|c|}{ Cyanotoxins } & \multicolumn{2}{|c|}{ Taste and odors } \\
\hline & Microcystins & Cylindrospermopsins & Geosmin & MIB \\
\hline Anabaenopsis & $\mathrm{X}$ & -- & -- & -- \\
\hline Aphanizomenon & -- & $\mathrm{X}$ & $\mathrm{X}$ & -- \\
\hline Aphanocapsa & $\mathrm{X}$ & -- & -- & -- \\
\hline Cylindrospermopsis & -- & $\mathrm{X}$ & -- & -- \\
\hline Dolichospermum (formerly Anabaena) & $\mathrm{X}$ & $\mathrm{X}$ & $\mathrm{X}$ & -- \\
\hline Limnothrix & $\mathrm{X}$ & -- & $\mathrm{X}$ & $\mathrm{X}$ \\
\hline Merismopedia & $\mathrm{X}$ & -- & -- & -- \\
\hline Microcystis & $\mathrm{X}$ & -- & -- & -- \\
\hline Oscillatoria (Planktothrix) & $\mathrm{X}$ & $\mathrm{X}$ & $\mathrm{X}$ & $\mathrm{X}$ \\
\hline Phormidium & $\mathrm{X}$ & -- & $\mathrm{X}$ & $\mathrm{X}$ \\
\hline Planktolyngbya & -- & -- & $\mathrm{X}$ & $\mathrm{X}$ \\
\hline Pseudanabaena & $\mathrm{X}$ & -- & $\mathrm{X}$ & $\mathrm{X}$ \\
\hline Raphidiopsis & -- & $\mathrm{X}$ & -- & -- \\
\hline
\end{tabular}

Wamego site, respectively. At the De Soto site, Aphanizomenon, Dolichospermum, and Microcystis were present in 26, 23 , and 23 percent of samples, respectively. Though potential cyanotoxin and taste-and-odor producers were present, genetic analyses are required to definitively determine which genera produce these compounds in the Kansas River (Graham and others, 2008; Otten and others, 2015; Otten and others, 2016; Graham and others, 2017).

Like chlorophyll and total phytoplankton abundance, cyanobacterial abundances typically were higher at the De Soto site than the Wamego site (table 2, fig. 6). On average, cyanobacterial abundance was 282 percent higher at the De Soto site than the Wamego site. Cyanobacterial abundances generally peaked in late summer or early fall (July through October), with smaller peaks occasionally observed in spring (April through May) (fig. 6). Cyanobacteria may be a concern for drinking-water treatment at abundances of 20,000 cells per milliliter (cells $/ \mathrm{mL}$ ) or higher (Taylor and other, 2005). Cyanobacterial abundance exceeded 20,000 cells $/ \mathrm{mL}$ in about 7 and 16 percent of the samples collected from the Wamego and De Soto sites, respectively, during July 2012 through September 2016. Exceedances typically occurred during summer months, though occasional exceedances were observed during spring and fall. Cyanobacterial dominance of the phytoplankton community typically occurred during summer or early fall. The most extended period of cyanobacterial dominance during the study period was observed during 2012, when cyanobacteria dominated the phytoplankton community for most of the summer.

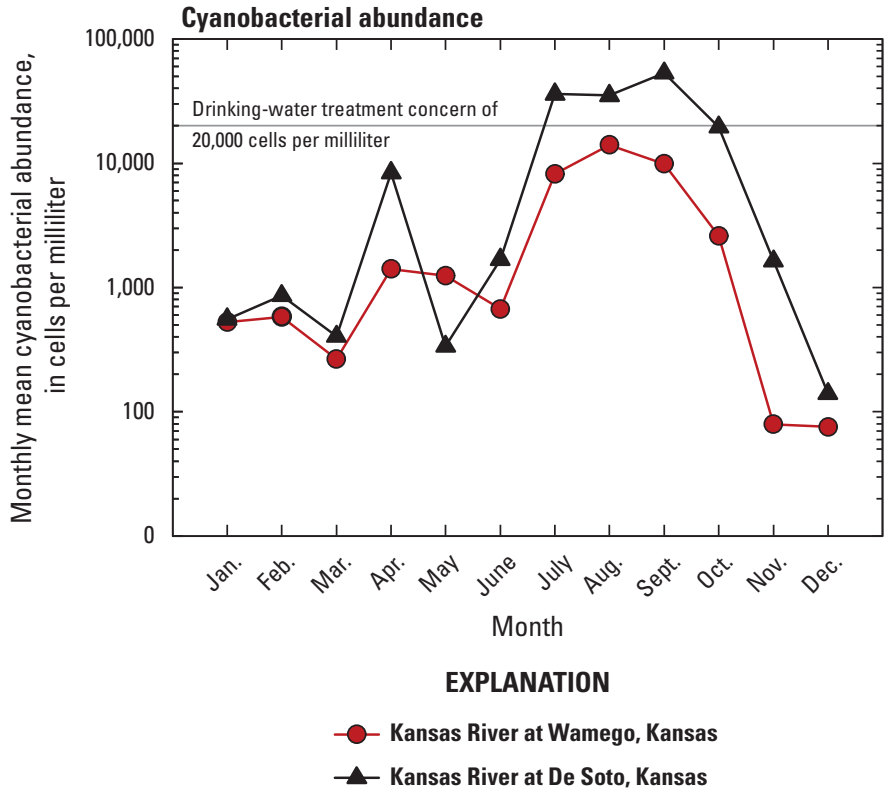

Figure 6. Monthly patterns in cyanobacterial abundance at the Kansas River at Wamego, Kansas, and Kansas River at De Soto, Kansas, streamgages (U.S. Geological Survey stations 06887500 and 06892350, respectively) during July 2012 through September 2016. 
Relations between cyanobacterial abundance and streamflow, turbidity, and nutrients in the Kansas River were similar to those for chlorophyll and total phytoplankton abundance, indicating the same processes that influence overall algal biomass and dynamics also are influencing cyanobacteria. Cyanobacterial abundances at the Wamego and De Soto sites were negatively, and relatively weakly, correlated with streamflow (all $R_{s}<-0.23$, all $p<0.05$ ). With the exception of orthophosphorus, there were negative, but relatively weak, relations between nutrients and cyanobacterial abundance (all $R_{s}<-0.23$, all $\left.p<0.04\right)$. The relation between orthophosphorus and cyanobacterial abundance was not statistically significant at the Wamego or De Soto sites. Cyanobacterial abundance was negatively correlated with turbidity at the De Soto site $\left(R_{s}=-0.24, p=0.03\right)$, but the relation between cyanobacterial abundance and turbidity was not statistically significant at the Wamego site.

\section{Cyanotoxins}

There are three main groups of cyanotoxins: hepatotoxins (affect the liver), neurotoxins (affect the central nervous system), and dermatoxins (affect the skin and mucous membranes) (Chorus and Bartram, 1999). The hepatotoxin microcystin was the only cyanotoxin detected in the Kansas River during 2011 (Graham and others, 2012); therefore, this study focused on microcystin. Cylindrospermopsin analysis was added in July 2015 after the EPA published guidance values for cylindrospermopsin in finished drinking water (U.S. Environmental Protection Agency, 2015). Microcystin is the most commonly detected cyanotoxin worldwide and occurs in lakes and reservoirs throughout the United States (Loftin and others, 2016). Overall, microcystin was detected in about 27 percent $(n=257)$ of the samples collected across all sites (main stem and tributaries). Total microcystin concentrations ranged from $<0.1$ to $2.41 \mu \mathrm{g} / \mathrm{L}$ (median $=<0.1 \mu \mathrm{g} / \mathrm{L}$ ) at the main-stem and tributary sites (fig. 7A). Cylindrospermopsin was detected in one sample across all sites (main-stem and tributaries), with a concentration of $0.05 \mu \mathrm{g} / \mathrm{L}$ at the De Soto site (laboratory reporting level: $0.05 \mu \mathrm{g} / \mathrm{L}$ ) during July 2015 through September 2016.

\section{Cyanotoxins in Kansas River Tributaries}

During July 2012 through September 2016, microcystin was detected most often and concentrations were highest in the Republican River downstream from Milford Lake (fig. 1). Microcystin was detected in about 64 percent of the samples $(n=28)$ collected from the Republican River, with concentrations ranging from $<0.1$ to $2.1 \mu \mathrm{g} / \mathrm{L}$ (median $=0.12 \mu \mathrm{g} / \mathrm{L}$ ). The EPA health advisory guidance values for finished drinking water of 0.3 and $1.6 \mu \mathrm{g} / \mathrm{L}$ (U.S. Environmental Protection Agency, 2015) were exceeded during the study period in 14 percent and 4 percent of the Republican River samples, respectively. These guidance values are for finished drinking water and are not directly applicable to observed environmental concentrations but do provide a benchmark for comparison. The highest microcystin concentrations in the Republican River were observed in August $2012(1.25 \mu \mathrm{g} / \mathrm{L})$ and July $2014(2.1 \mu \mathrm{g} / \mathrm{L})$. Microcystin concentrations in the Republican River during July 2012 through September 2016 were lower than observed during September through October 2011, when microcystin concentrations ranged from $<0.1$ to $7.4 \mu \mathrm{g} / \mathrm{L}$ (median $=0.26 \mu \mathrm{g} / \mathrm{L}$ ) and exceeded 0.3 and $1.6 \mu \mathrm{g} / \mathrm{L}$ in about 43 and 21 percent of the samples, respectively (Graham and others, 2012).

Microcystin was detected less frequently in the Big Blue River (downstream from Tuttle Creek Lake) and the Delaware River (downstream from Perry Lake). Microcystin was detected in about 10 percent of the samples $(n=21)$ collected from the Big Blue River (range $=<0.1$ to $0.22 \mu \mathrm{g} / \mathrm{L}$; median $=<0.1 \mu \mathrm{g} / \mathrm{L}$ ). Microcystin was detected in about 44 percent of the samples $(n=25)$ collected from the Delaware River (range $=<0.1$ to $0.71 \mu \mathrm{g} / \mathrm{L}$; median $=<0.1 \mu \mathrm{g} / \mathrm{L}$ ). Concentrations exceeded $0.3 \mu \mathrm{g} / \mathrm{L}$ in 12 percent of Delaware River samples. The highest microcystin concentrations in the Delaware River were observed in August $2012(0.63 \mu \mathrm{g} / \mathrm{L})$, September 2014 $(0.4 \mu \mathrm{g} / \mathrm{L})$, and October $2015(0.71 \mu \mathrm{g} / \mathrm{L})$. Maximum microcystin concentrations observed in the Big Blue and Delaware Rivers during July 2012 through September 2015 were about 2 times higher than those observed in 2011 (Graham and others, 2012).

\section{Cyanotoxins in the Kansas River Main Stem}

Microcystin occurrence and concentration were similar between the Wamego and De Soto sites during July 2012 through September 2016. Microcystin was detected in about 20 and 23 percent of the samples collected from the Wamego $(n=90)$ and De Soto $(n=93)$ sites, respectively (table 4). Microcystin concentrations ranged from $<0.1$ to $1.7 \mu \mathrm{g} / \mathrm{L}$ at the Wamego site and $<0.1$ to $2.41 \mu \mathrm{g} / \mathrm{L}$ at the De Soto site (both site medians $<0.1 \mu \mathrm{g} / \mathrm{L}$, table 4 ). At the Wamego site, microcystin concentration exceeded the EPA health advisory guidance values for finished drinking water of 0.3 and $1.6 \mu \mathrm{g} / \mathrm{L}$ in about 6 and 1 percent of the samples, respectively. Similarly, at the De Soto site, microcystin concentrations exceeded 0.3 and $1.6 \mu \mathrm{g} / \mathrm{L}$ in about 5 and 1 percent of the samples, respectively. The EPA health advisory guidance values are for finished drinking water and are not directly applicable to observed environmental concentrations but do provide a benchmark for comparison.

Seasonal patterns in microcystin occurrence were consistent between sites and among years. Microcystin was detected most often and had the highest concentrations during summer (fig. 7A). Overall, microcystin was detected in 39 percent of summer samples $(n=75)$. Microcystin was typically first detected (greater than or equal to $[\geq] 0.1 \mu \mathrm{g} / \mathrm{L}$ ) in June or July, increased to the annual maxima during July through September, and then decreased. This seasonal pattern is similar to the overall pattern for cyanobacterial abundance (fig. 6). Though 

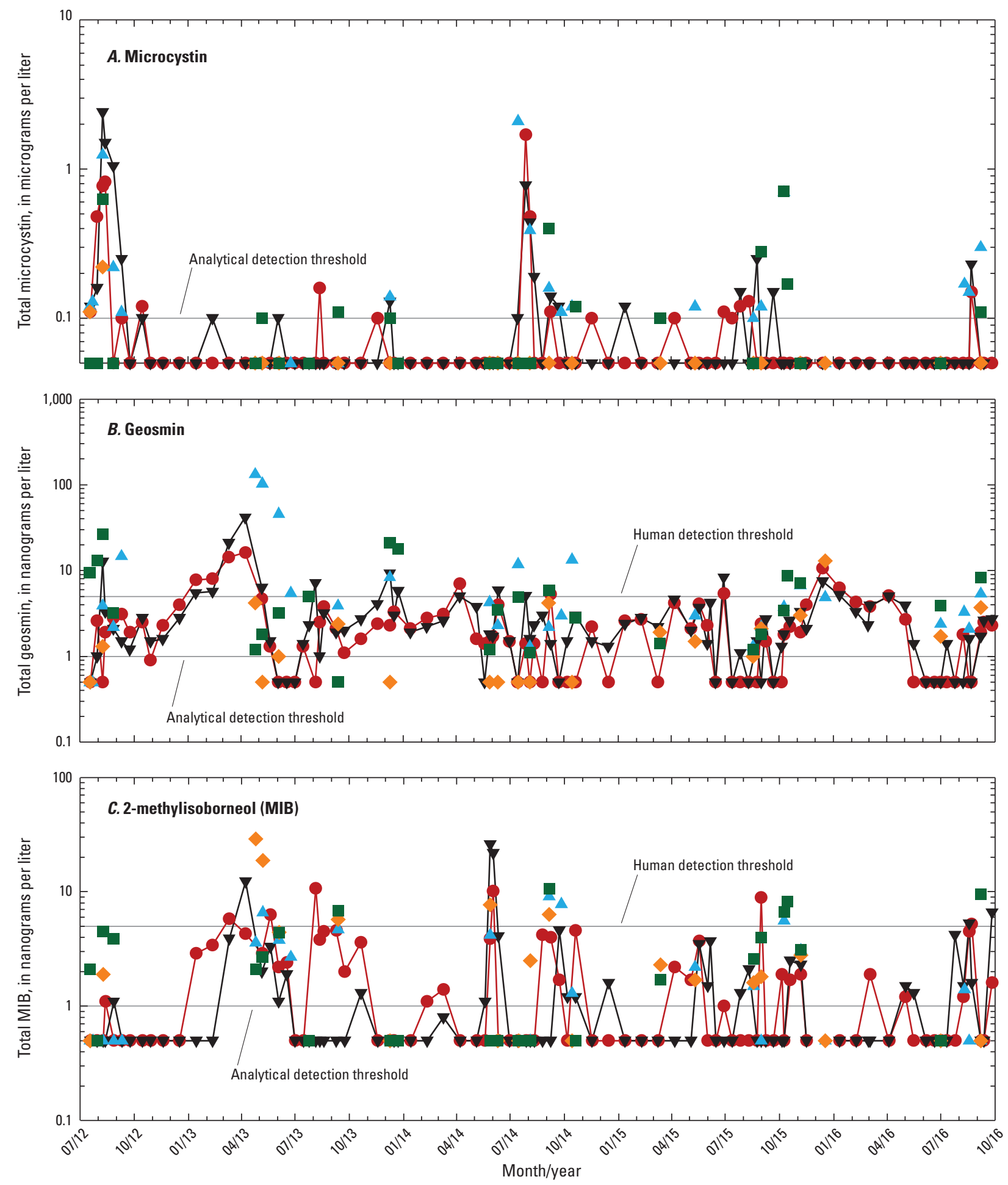

\section{EXPLANATION}

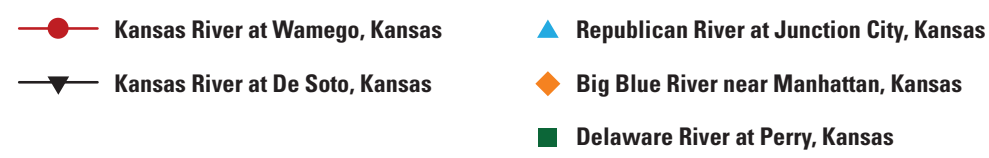

Figure 7. Occurrence of toxins and taste-and-odor compounds at the Kansas River at Wamego, Kansas; Kansas River at De Soto, Kansas; Republican River at Junction City, Kansas; Big Blue River near Manhattan, Kansas; and Delaware River at Perry, Kansas, streamgages (U.S. Geological Survey stations 06887500, 06892350, 06857100, 06887000, and 06890900, respectively) during July 2012 through September 2016. A, microcystin. B, geosmin. C, 2-methylisoborneol (MIB). 
Table 4. Summary statistics for cyanobacterial toxins and taste-and-odor compounds at the Kansas River at Wamego, Kansas, and Kansas River at De Soto, Kansas, streamgages (U.S. Geological Survey stations 06887500 and 06892350 , respectively) during July 2012 through September 2016.

[MIB, 2-methylisoborneol; $n$, number of samples; <, less than]

\begin{tabular}{|c|c|c|c|c|c|c|c|c|}
\hline & \multicolumn{2}{|c|}{$\begin{array}{c}\text { Microcystins, } \\
\text { in micrograms per liter }\end{array}$} & \multicolumn{2}{|c|}{$\begin{array}{l}\text { Cylindrospermopsins, } \\
\text { in micrograms per liter }\end{array}$} & \multicolumn{2}{|c|}{$\begin{array}{c}\text { Geosmin, } \\
\text { in nanograms per liter }\end{array}$} & \multicolumn{2}{|c|}{$\begin{array}{c}\text { MIB, } \\
\text { in nanograms per liter }\end{array}$} \\
\hline & Wamego & De Soto & Wamego & De Soto & Wamego & De Soto & Wamego & De Soto \\
\hline$n$ & 90 & 93 & 29 & 29 & 90 & 94 & 90 & 94 \\
\hline Minimum & $<0.1$ & $<0.1$ & $<0.05$ & $<0.05$ & $<1$ & $<1$ & $<1$ & $<1$ \\
\hline Median & $<0.1$ & $<0.1$ & $<0.05$ & $<0.05$ & 1.90 & 2.05 & $<1$ & $<1$ \\
\hline Maximum & 1.70 & 2.41 & $<0.05$ & 0.05 & 16.2 & 41.6 & 10.7 & 25.9 \\
\hline Detection limit & 0.10 & 0.10 & 0.05 & 0.05 & 1.0 & 1.0 & 1.0 & 1.0 \\
\hline Nondetects & 72 & 72 & 29 & 28 & 30 & 18 & 52 & 63 \\
\hline Percent detection & 20 & 23 & 0 & 3 & 67 & 81 & 42 & 33 \\
\hline
\end{tabular}

seasonal patterns in microcystin occurrence were generally consistent, seasonal maxima varied by an order of magnitude across years (fig. $7 A$ ).

The highest microcystin concentrations were observed in August 2012 (Wamego site maximum $=0.82 \mu \mathrm{g} / \mathrm{L}$; De Soto site maximum $=2.41 \mu \mathrm{g} / \mathrm{L}$ ) and July 2014 (Wamego site maximum $=1.7 \mu \mathrm{g} / \mathrm{L}$; De Soto site maximum=0.78, fig. $7 A$ ). Cyanobacteria dominated the algal community during these time periods. Microcystin concentrations observed in the Kansas River during July 2012 through September $2016(<0.1$ to $2.41 \mu \mathrm{g} / \mathrm{L}$ ) were similar to those observed during September through October $2011(<0.1$ to $2.7 \mu \mathrm{g} / \mathrm{L})$; however, the maximum microcystin concentration observed at the De Soto site in the current study $(2.41 \mu \mathrm{g} / \mathrm{L})$ was about 3 times higher than observed in $2011(0.80 \mu \mathrm{g} / \mathrm{L})$ (Graham and others, 2012).

Dissolved-phase cyanotoxins may persist for several days to weeks after the decline of a cyanobacterial population and may be more difficult to remove than particulate-bound cyanotoxins during drinking-water treatment processes (Jones and Orr, 1994; Heresztyn and Nicholson, 1997; Chiswell and others, 1999; Chorus and Bartram, 1999). Dissolved microcystin was measured in most samples where total microcystin concentrations were $>0.1 \mu \mathrm{g} / \mathrm{L}$. About 8 percent of Kansas River main-stem samples $(n=183)$ collected during the study period were analyzed for dissolved microcystin concentrations (Williams and others, 2018). Dissolved microcystin represented between 6 and 100 percent of total microcystin concentrations (median=43 percent, $n=15$ ). When total concentrations were $>0.3 \mu \mathrm{g} / \mathrm{L}$ and dissolved concentrations were measured $(n=6)$, dissolved microcystin represented between 6 and 21 percent of total concentrations (median $=13$ percent). These data indicated that the dissolved phase infrequently dominated the microcystin pool in the Kansas River when total microcystin was above detectable levels.

\section{Taste-and-Odor Compounds}

The taste-and-odor causing compounds geosmin and MIB can create earthy and (or) musty tastes and odors in finished drinking water when present at concentrations $>5$ to $10 \mathrm{ng} / \mathrm{L}$. Geosmin and MIB are produced by several microorganisms, including actinomycetes bacteria; however, cyanobacteria are typically the cause of geosmin- and MIB-related taste-andodor episodes in source water supplies (Taylor and others, 2005). Overall, geosmin and MIB were detected in about 78 and 43 percent of samples $(n=258)$, respectively, collected across all sites (main stem and tributaries) during July 2012 through September 2016. Total geosmin and MIB concentrations ranged from $<1$ to $133 \mathrm{ng} / \mathrm{L}$ (median=2.2 ng/L) and $<1$ to $29 \mathrm{ng} / \mathrm{L}$ (median=<1 ng/L), respectively (figs. $7 B, C$ ). The human detection threshold of $5 \mathrm{ng} / \mathrm{L}$ was exceeded in about 18 percent of geosmin samples and 10 percent of MIB samples.

\section{Geosmin and 2-Methylisoborneol in Kansas River Tributaries}

During July 2012 through September 2016, both geosmin and MIB were frequently detected in all tributary streams, though patterns in occurrence and concentration varied among sites. Geosmin and MIB were detected in about 93 and 50 percent $(n=28)$ of samples, respectively, collected from the Republican River. Concentrations ranged from $<1$ to $133 \mathrm{ng} / \mathrm{L}$ (median=3.85 ng/L) and $<1$ to $9.1 \mathrm{ng} / \mathrm{L}$ (median $<1.45 \mathrm{ng} / \mathrm{L}$ ), respectively. Geosmin and MIB exceeded the human detection threshold of $5 \mathrm{ng} / \mathrm{L}$ in about 36 and 14 percent of samples, respectively. The highest geosmin concentrations in the Republican River were observed during April through June of 2013 (maxima $=45.8$ to $133.1 \mathrm{ng} / \mathrm{L}$; fig. $7 B$ ). The highest MIB 
concentration $(9.1 \mathrm{ng} / \mathrm{L})$ occurred during September 2014

(fig. 7C) (Williams and others, 2018).

In the Big Blue River, geosmin and MIB were detected in about 62 percent of samples $(n=21)$. Geosmin and MIB concentrations ranged from $<1$ to $13 \mathrm{ng} / \mathrm{L}$ (median $=<1.5 \mathrm{ng} / \mathrm{L}$ ) and $<1$ to $29 \mathrm{ng} / \mathrm{L}$ (median=1.9 ng/L), respectively. Geosmin exceeded $5 \mathrm{ng} / \mathrm{L}$ in about 5 percent of samples, and MIB in about 24 percent. The highest geosmin concentration occurred in December 2015 (maximum=13 ng/L; the only sample that exceeded the human detection threshold). The highest MIB concentrations occurred during April through May 2013 (maxima $=18.7$ to $29 \mathrm{ng} / \mathrm{L}$ ) (Williams and others, 2018).

In the Delaware River, geosmin and MIB were detected in about 96 and 60 percent of samples $(n=25)$, respectively. Geosmin and MIB concentrations ranged from $<1$ to $26.6 \mathrm{ng} / \mathrm{L}$ (median=3.5 ng/L) and $<1$ to $10.6 \mathrm{ng} / \mathrm{L}$ (median=2.1 ng/L), respectively. Geosmin and MIB exceeded $5 \mathrm{ng} / \mathrm{L}$ in 36 and 20 percent of samples, respectively. The highest geosmin concentrations were observed during July through August 2012 (maxima $=13.1$ to $26.6 \mathrm{ng} / \mathrm{L}$ ) and December 2013 (max$\mathrm{ima}=17.9$ to $21.2 \mathrm{ng} / \mathrm{L}$ ). The highest MIB concentration was observed in September 2014 (maximum=10.6 ng/L) (Williams and others, 2018).

Geosmin and MIB concentrations in the Kansas River tributary streams during July 2012 through September 2016 were substantially higher than September through October 2011. With one exception, maximum geosmin and MIB concentrations at all sites were about 3 to 6 times higher from July 2012 through September 2016 than in September through October 2011 (Graham and others, 2012), most likely because the longer study duration captured a wider range of conditions. The exception was MIB at the Delaware River site, downstream from Perry Reservoir where maximum MIB concentrations in 2011 were about 3 times higher than the maximum concentration observed from July 2012 through September 2016.

\section{Geosmin and 2-Methylisoborneol in the Kansas River Main Stem}

Unlike microcystin, geosmin and MIB occurrence and concentration varied considerably between the Wamego and De Soto sites during July 2012 through September 2016. Detection frequency of geosmin was higher at the De Soto site than the Wamego site, reflecting overall patterns in algal biomass and actinomycetes abundance (tables 2, 4). Geosmin was detected in about 67 percent of Wamego samples $(n=90)$ and 81 percent of De Soto samples ( $n=94$; table 4$)$. Geosmin concentrations at the Wamego and De Soto sites ranged from $<1$ to $16.2 \mathrm{ng} / \mathrm{L}$ (median=1.9 ng/L) and $<1$ to $41.6 \mathrm{ng} / \mathrm{L}$ (median=2.05 ng/L), respectively (table 4). The human detection threshold of $5 \mathrm{ng} / \mathrm{L}$ was exceeded for geosmin in about 11 and 17 percent of the samples collected at the Wamego and De Soto sites, respectively. Geosmin concentrations $\geq 5 \mathrm{ng} / \mathrm{L}$ were detected in all years, except for 2012 at the Wamego site. Although percent detection and range of concentrations of geosmin differed among the Wamego and De Soto sites, overall patterns in occurrence were quite consistent throughout the study period (fig. $7 B$ ). The highest geosmin concentrations occurred at both sites in April 2013 (Wamego site maximum $=16.2 \mathrm{ng} / \mathrm{L}$; De Soto site maximum=41.6 ng/L). Cyanobacteria did not dominate the phytoplankton community during April 2013. Geosmin was detected during all months of the year at both sites, and there were no clear seasonal patterns (fig. 7B); however, 80 percent of concentrations $\geq 5 \mathrm{ng} / \mathrm{L}$ at the Wamego site $(n=10)$ and 62 percent of such concentrations at the De Soto site $(n=16)$ were observed during December through April.

MIB was detected less frequently in the Kansas River than geosmin and was observed in about 42 percent of Wamego samples $(n=90)$ and 33 percent of De Soto samples ( $n=94$; table 4). MIB concentrations also were lower than geosmin concentrations, ranging from $<1$ to $10.7 \mathrm{ng} / \mathrm{L}$ at the Wamego site and $<1$ to $25.9 \mathrm{ng} / \mathrm{L}$ at the De Soto site (both site medians $=<1 \mathrm{ng} / \mathrm{L}$; table 4). Concentrations exceeded $5 \mathrm{ng} / \mathrm{L}$ in about 7 and 5 percent of samples from the Wamego and De Soto sites, respectively. MIB concentrations $\geq 5 \mathrm{ng} / \mathrm{L}$ were detected in all years, except for 2012 at the Wamego site and 2012 and 2015 at the De Soto site. At the Wamego site, the highest MIB concentrations were observed in August 2013 (10.7 ng/L), June 2014 (10.1), and August 2015 (8.9 ng/L). Cyanobacteria did not dominate the phytoplankton community in August 2013. At the De Soto site, the highest MIB concentrations were observed during May through June 2014 (maxima $=21.8$ to $25.9 \mathrm{ng} / \mathrm{L}$ ); cyanobacteria did not dominate the phytoplankton community during this time period. As observed for geosmin, there were no clear seasonal patterns in MIB occurrence or concentration (fig. 7C).

Similar to the tributary streams, geosmin and MIB concentrations in the Kansas River were higher during July 2012 through September 2016 than September through October 2011, though differences were not as pronounced. Maximum geosmin and MIB concentrations were about 1.2 to 2 times higher during July 2012 through September 2016 than during September through October 2011 (Graham and others, 2012). Higher concentrations likely were observed in this study because the longer duration captured a wider range of conditions.

Like the cyanotoxins, dissolved-phase taste-and-odor compounds may be more difficult to remove than particulatebound taste-and-odor compounds during drinking-water treatment processes. Dissolved geosmin and MIB were measured in samples where total concentrations of one or both compounds were $>5 \mathrm{ng} / \mathrm{L}$. About 28 percent of Kansas River main-stem samples $(n=184)$ collected during the study period were analyzed for dissolved geosmin and MIB concentrations. Overall, dissolved geosmin and MIB represented between 0 and 100 percent of total concentrations (both medians $=0$ percent; both $n=52$ ). When total concentrations were $\geq 5 \mathrm{ng} / \mathrm{L}$, dissolved geosmin represented a larger portion of the total concentration (median $=65$ percent; $n=20$ ). Dissolved MIB still 
represented a small portion of the total concentration when concentrations were $\geq 5 \mathrm{ng} / \mathrm{L}$ (median $=0 ; n=6$ ), but the small number of samples may influence this result. These data indicate that the dissolved phase may dominate the geosmin pool in the Kansas River when concentrations are high, potentially creating additional challenges for drinking-water treatment.

\section{Co-Occurrence of Cyanotoxins and Taste-and- Odor Compounds}

Optimal drinking-water treatment processes can be complicated by the presence of cyanotoxins, taste-and-odor compounds, or mixtures of the two (Westrick and others, 2010). Both share multiple common potential producers (Graham and others, 2008), and co-occurrence of cyanotoxins and taste-andodor compounds can be expected (Graham and others, 2010). The cyanotoxin microcystin and the taste-and-odor compounds geosmin and MIB co-occurred in 91 percent of cyanobacterial blooms $(n=23)$ sampled in Midwestern United States lakes (Graham and others, 2010). By comparison, microcystin co-occurred with geosmin and MIB in 22 percent of routinely collected integrated photic zone samples $(n=213)$ from Cheney Reservoir, Kans. (Graham and others, 2017).

During July 2012 through September 2016, geosmin was detected more frequently in the Kansas River tributary and main-stem sites ( 78 percent of samples; $n=258$ ) than MIB (43 percent of samples; $n=258$ ) or microcystin (27 percent of samples; $n=257$ ). Overall, only 10 percent of samples analyzed for microcystin, geosmin, and MIB did not have detectable concentrations of at least one of these compounds $(n=257$; fig. 8). Microcystin and taste-and-odor compounds (either geosmin, MIB, or both) co-occurred in 22 percent of samples, similar to co-occurrence in routinely collected samples from Cheney Reservoir (Graham and others, 2017). Co-occurrence in the Kansas River and Cheney Reservoir may be similar because both studies focused on routinely collected samples, rather than samples collected during bloom events such as the Graham and others $(2010,2012)$ studies. Therefore, though microcystin and taste-and-odor compounds can occasionally occur together, presence of one may not be indicative of presence of the other. Furthermore, sufficient warning for human health protection cannot be provided by the presence of odor alone (Graham and others, 2017).

\section{Environmental Factors Associated with Occurrence of Cyanotoxins and Taste- and-Odor Compounds}

Streamflow, reservoir contributions to flow, and all waterquality variables were included in an analysis of potential factors associated with occurrence of microcystin, geosmin, and MIB in the Kansas River during July 2012 through September

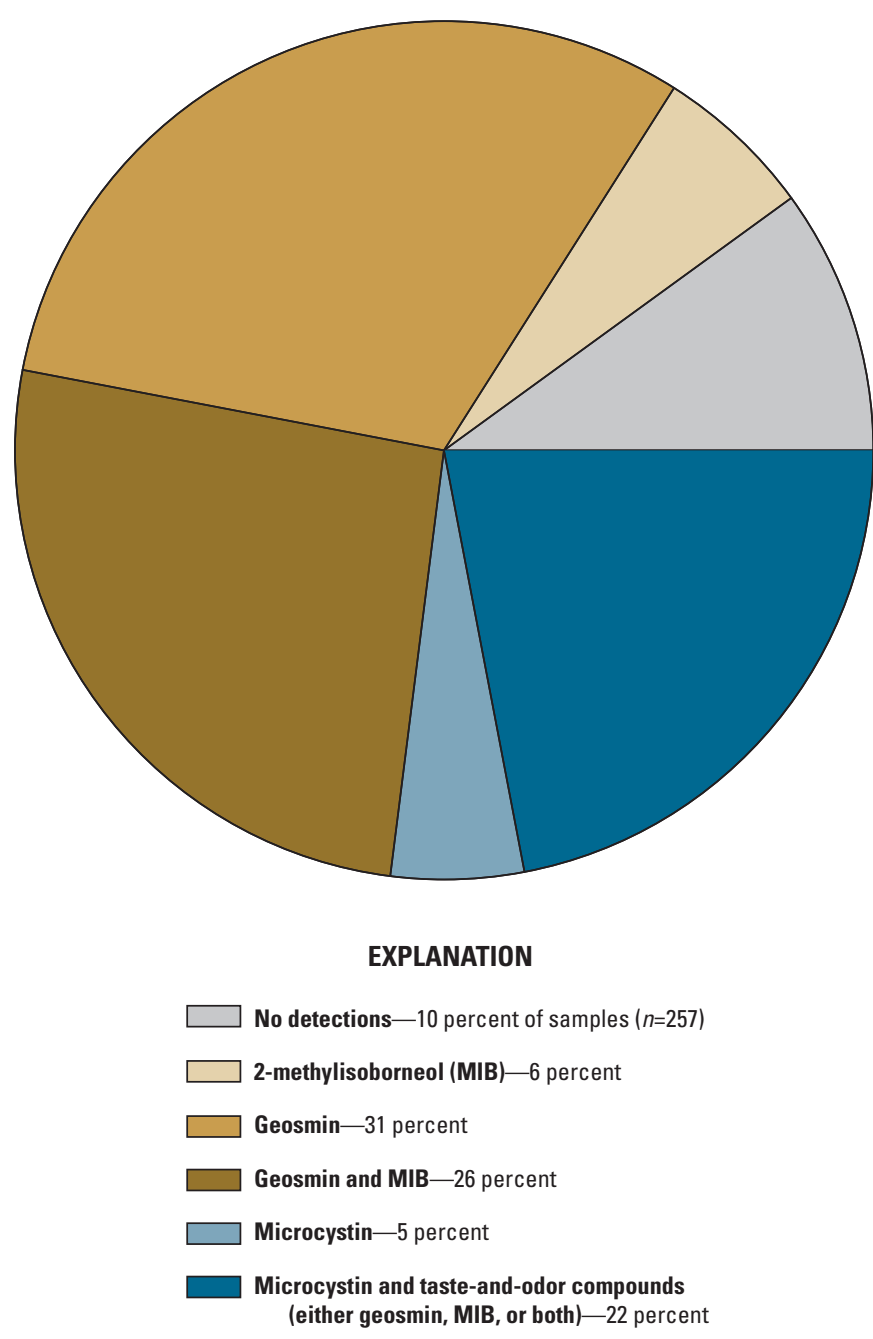

Figure 8. Co-occurrence of microcystin and taste-and-odor compounds in samples at the Kansas River at Wamego, Kansas; Kansas River at De Soto, Kansas; Republican River at Junction City, Kansas; Big Blue River near Manhattan, Kansas; and Delaware River at Perry, Kansas, streamgages (U.S. Geological Survey stations 06887500, 06892350, 06857100, 06887000, and 06890900, respectively) collected during July 2012 through September 2016.

2016. The nonparametric Mann-Whitney rank sum test and Spearman rank-correlation analysis were used to characterize environmental conditions when microcystin, geosmin, and MIB occurred above concentrations of $0.3 \mu \mathrm{g} / \mathrm{L}, 5 \mathrm{ng} / \mathrm{L}$, or $2 \mathrm{ng} / \mathrm{L}$, respectively. These concentrations were selected based on values relevant to drinking-water treatment and the distribution of the data (U.S. Environmental Protection Agency, 2015; Taylor and others, 2005) and were used as thresholds to define microcystin, geosmin, and MIB events. 


\section{Microcystin}

Microcystin was detected in about 20 percent of Kansas River main-stem samples collected during the study period, though concentrations were typically $<0.3 \mu \mathrm{g} / \mathrm{L}$. Microcystin was always detected during the summer months when cyanobacterial abundances were highest in the Kansas River; however, microcystin concentrations $>0.3 \mu \mathrm{g} / \mathrm{L}$ were only observed during the summers of 2012 and 2014 (fig. 7A). Because of the low detection frequency and high microcystin concentrations associated with two events during the study period, correlation analysis was not a valid method for determining environmental factors that were associated with microcystin occurrence and concentration; however, environmental conditions during the entire 2012 and 2014 summers (July through September) in which microcystin events occurred were compared with conditions during other summers.

Median streamflows during summers 2012 and 2014 were about 2.5 times less than streamflows during nonevent summers at the Wamego and De Soto sites (table 5). When microcystin concentrations were $>0.3 \mu \mathrm{g} / \mathrm{L}$, total streamflow was always $<3,000 \mathrm{ft}^{3} / \mathrm{s}$. In addition, reservoir contribution to total streamflow was nearly 1.5 times greater during the summer 2012 and 2014 microcystin events relative to nonevent summers. In particular, streamflow contributions from Milford Lake when microcystin concentrations were $>0.3 \mu \mathrm{g} / \mathrm{L}$ ranged from 36 to 57 and 11 to 34 percent of total streamflow at the Wamego and De Soto sites, respectively. Milford Lake contributions to total streamflow during the 2012 and 2014 microcystin event summers (July through September) were about 3 to 4.5 times greater than contributions during nonevent summers (table 5 , fig. 4 ).

In addition to streamflow and reservoir contributions to flow, algal biomass, cyanobacterial abundance, and several continuously measured water-quality variables were significantly different during microcystin event summers (2012 and 2014) relative to nonevent summers at the Wamego and De Soto sites. Median regression estimated-chlorophyll concentrations were about 1.5 to 2 times greater during microcystin event summers at the Wamego and De Soto sites, respectively. Turbidity was significantly lower and specific conductance and pH were significantly higher during 2012 and 2014 than other summers (tables 2, 5). Less material suspended throughout the water column and more light penetration may create favorable conditions for cyanobacterial growth and microcystin production in the Kansas River (Reynolds, 1984; Chorus and Bartram, 1999; Wetzel, 2001). Higher specific conductance values during the summer 2012 and 2014 microcystin events may be an artifact of low-flow conditions rather than a potential influence on microcystin occurrence (Hem, 1992). Algal biomass and cyanobacterial abundance were significantly higher during event summers (tables 2,5) and likely resulted in higher Kansas River $\mathrm{pH}$ values caused by increased photosynthesis (Wetzel, 2001).

During September through October 2011 (not shown) and July 2012 through September 2016, peak microcystin concentrations in the Kansas River main stem coincided with peak concentrations in the Republican River (fig. 7A; Graham and others, 2012). In addition, during July 2012 through September 2016 peak microcystin concentrations at the Delaware River usually coincided with elevated concentrations at the downstream De Soto site (fig. 7A). Streamflow, reservoir contributions to total streamflow, and contributions from Milford Lake in particular were significantly different between summers with and without microcystin events (table 5). During the 2012 and 2014 microcystin events, streamflows were low $\left(<3,000 \mathrm{ft}^{3} / \mathrm{s}\right)$ and Milford Lake contributions to total streamflows were relatively high (36 percent or more of total streamflow at the Wamego site and 11 percent or more at the De Soto site; table 5, fig. 4) when microcystin concentrations were $>0.3 \mu \mathrm{g} / \mathrm{L}$. By comparison, when microcystin was detected in the Kansas River during the September through October 2011 microcystin event, Milford contributed 40 percent or more to total streamflows at the Wamego site and 30 percent or more at the De Soto site (Graham and others, 2012). Streamflows at the beginning of the 2011 event were similar to streamflows during the summer 2012 and 2014 events but were substantially higher throughout the 2011 event (maxima of about 14,600 to $15,800 \mathrm{ft}^{3} / \mathrm{s}$ at the Wamego and De Soto sites, respectively) because of ongoing reservoir releases. Even though maximum streamflows were higher during the 2011 event, the highest measured microcystin concentrations were observed at streamflows around $3,000 \mathrm{ft}^{3} / \mathrm{s}$ or less (Graham and others, 2012).

There seems to be a connection between microcystin detections in the Kansas River and occurrence of microcystin in upstream reservoirs (and tributary streams). Microcystin concentrations $>0.3 \mu \mathrm{g} / \mathrm{L}$ may be likely during the summer when streamflow is $<3,000 \mathrm{ft}^{3} / \mathrm{s}$ and contributions from Milford Lake exceed about 30 percent of total flow in the Kansas River. Observed microcystin concentrations typically were higher at the De Soto site than the Wamego or tributary sites during 2012 through 2016, indicating cyanobacteria may continue to grow and produce microcystin once introduced to the Kansas River. Downstream increases in microcystin concentration have been previously reported in the Kansas River by Graham and others (2012). Similar downstream transport and growth of microcystin-producing cyanobacteria from upstream reservoir sources have been observed in the Klamath River in Oregon and California (Kann and others, 2010; Otten and others, 2015) and the Tualatin River in Oregon (Rounds and others, 2015).

\section{Taste-and-Odor Compounds}

Geosmin and MIB were detected in about 74 (Wamego site) and 38 (De Soto site) percent of the Kansas River main-stem samples collected during the study period, though concentrations were typically less than the human detection threshold of $5 \mathrm{ng} / \mathrm{L}$. As observed in 2011 (Graham and others, 2012), the spatial and temporal patterns in geosmin and 


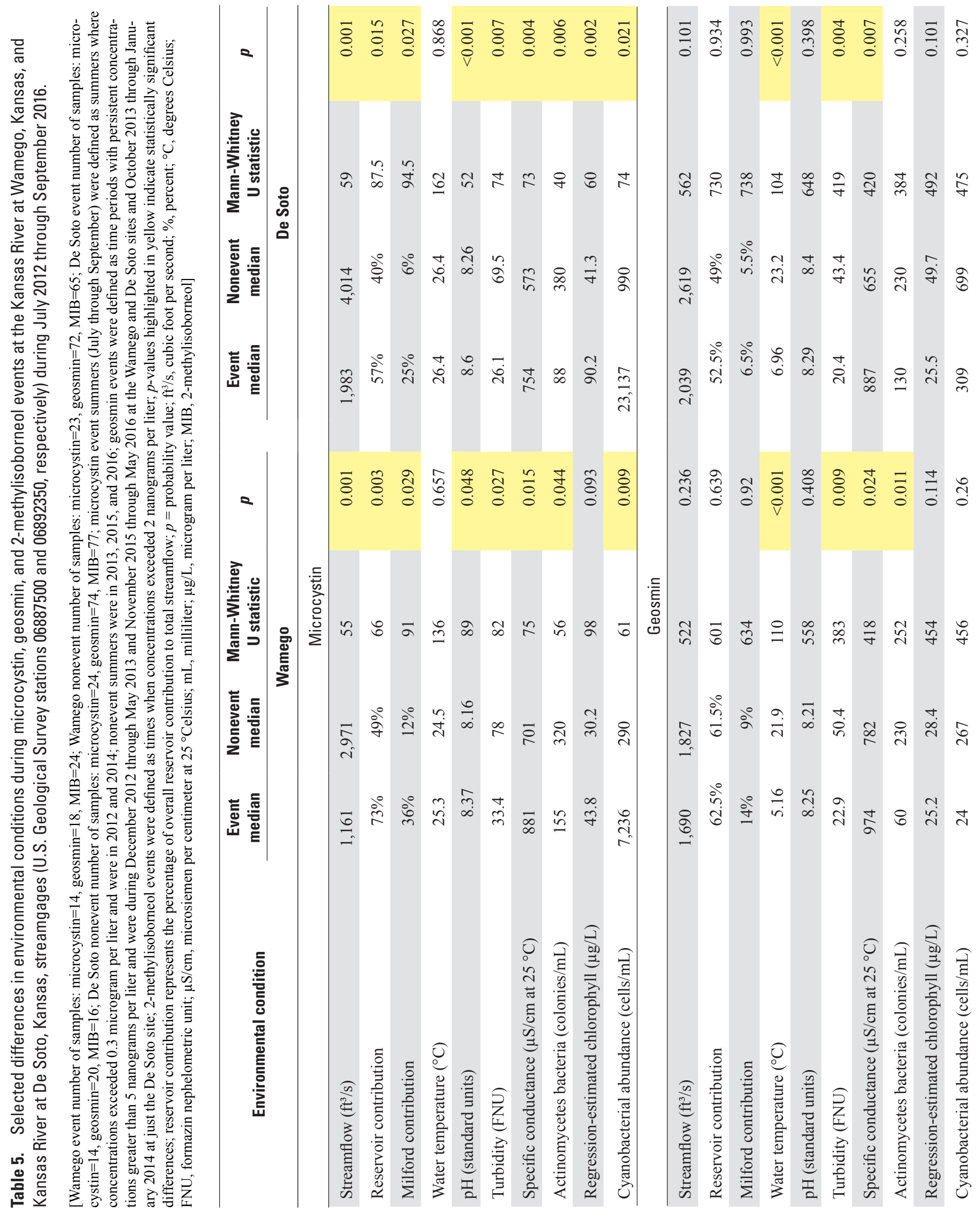




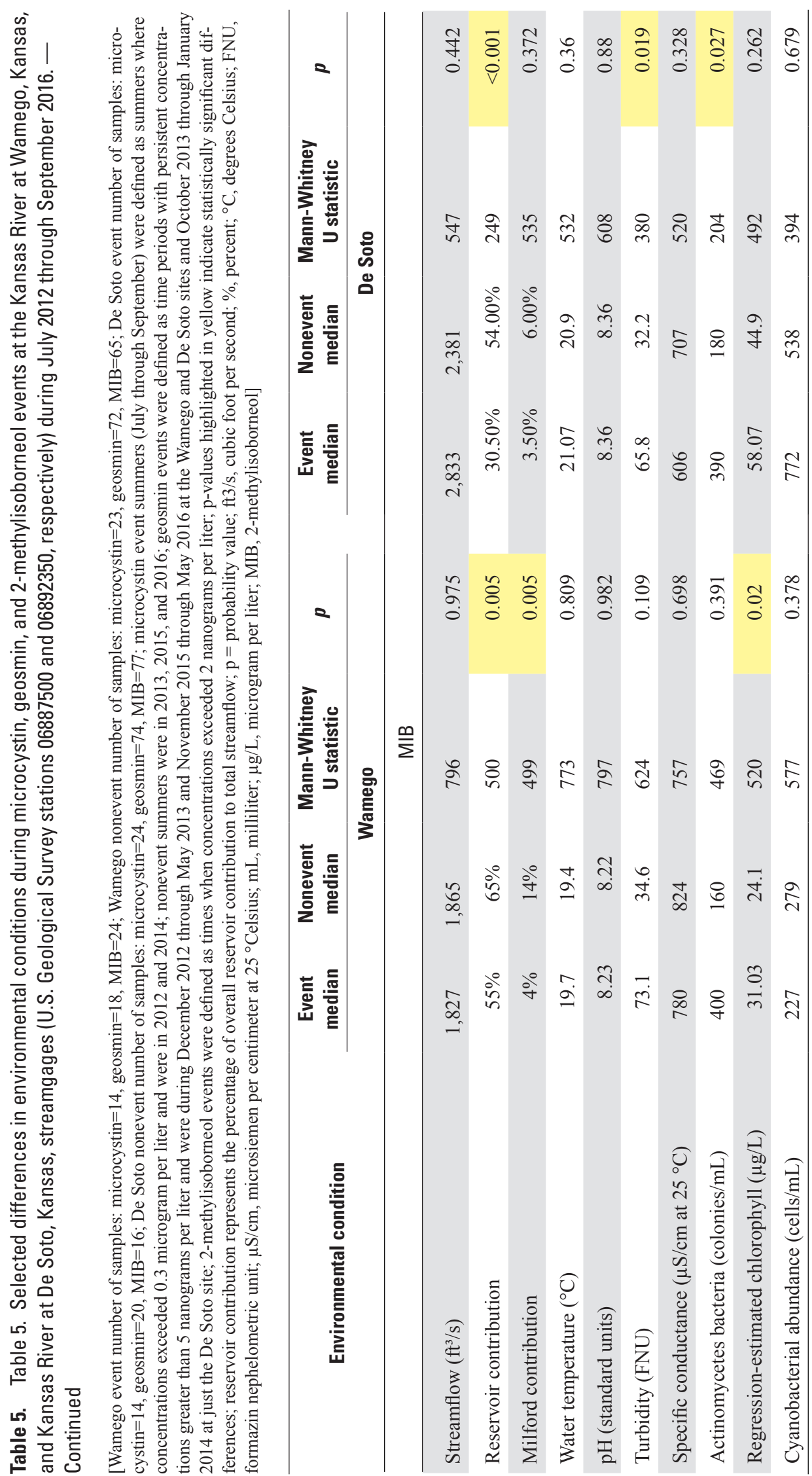


MIB occurrence and concentration were more complex than microcystin. Detections occurred throughout the year and were not necessarily concurrent at the Wamego and De Soto sites (figs. $7 B, C$ ). There were two geosmin events (time periods with persistent detections and maxima $>5 \mathrm{ng} / \mathrm{L}$ ) that affected the Wamego and De Soto sites (December 2012 through May 2013 and November 2015 through May 2016) and one event that affected just the De Soto site (October 2013 through January 2014) (fig. 7B). Sixty-five percent of geosmin concentrations $>5 \mathrm{ng} / \mathrm{L}(n=26)$ were observed during these three events; other exceedances had short durations ( $<2$ weeks). Therefore, environmental conditions during the three longer-duration geosmin events were compared with nonevent environmental conditions. Although MIB detections did occasionally exceed the human detection threshold of $5 \mathrm{ng} / \mathrm{L}$ during the study period, long duration events did not occur (fig. 7C), precluding an event-based analysis similar to microcystin and geosmin. Instead, environmental conditions when concentrations exceeded $2 \mathrm{ng} / \mathrm{L}$ were compared to environmental conditions when concentrations were $<2 \mathrm{ng} / \mathrm{L}$.

In contrast to microcystin, streamflow and reservoir contributions to streamflow were not significantly different during geosmin events and nonevent periods. Geosmin events occurred across the range of streamflow conditions and flow contributions from Milford, Tuttle Creek, and Perry Lakes (table 5; figs. 4 and 7B). Although the highest geosmin concentrations were observed during the lowest streamflows at the Wamego and De Soto sites, concentrations $>5 \mathrm{ng} / \mathrm{L}$ also were observed across the entire range of flow conditions at both sites; however, runoff events may have been an important factor associated with MIB occurrence. Reservoir contributions to total streamflow were nearly 10 to 24 percent less when MIB concentrations were $>2 \mathrm{ng} / \mathrm{L}$ than when concentrations were $<2 \mathrm{ng} / \mathrm{L}$. These results, combined with an overall lack of concurrent, relatively high concentrations, at main-stem and tributary sites (figs. $7 B, C$ ) indicate there are no clear connections between geosmin and MIB occurrence in the Kansas River and potential upstream reservoir (or tributary stream) sources.

There was not a clear relation between algal biomass or cyanobacteria and taste-and-odor events in the Kansas River. With the exception of MIB and chlorophyll at the Wamego site, regression-estimated chlorophyll concentrations and cyanobacterial abundance were not significantly different during geosmin events or when MIB concentrations were $>2 \mathrm{ng} / \mathrm{L}$ (table 5), and correlations were not statistically significant. Actinomycetes bacteria typically are associated with runoff events and also may produce geosmin and MIB. The abundance of actinomycetes bacteria was significantly lower during geosmin events at the Wamego site and significantly higher during MIB events at the De Soto site (table 5). Similarly, geosmin was significantly, but negatively, correlated with actinomycetes bacteria $(R=-0.28, \mathrm{p}=0.02)$ at the Wamego site, and MIB was significantly and positively correlated with actinomycetes bacteria at the De Soto site $\left(R_{s}=0.353, p<0.01\right)$.
The lack of clear associations with potential producers may be indicative of multiple geosmin and MIB sources in the Kansas River.

Geosmin and MIB were not strongly correlated (all $\left.R_{s}<0.55\right)$ with any continuously measured environmental variable at either Kansas River site. Water temperature, turbidity, and specific conductance were the only environmental variables that were significantly different during geosmin events at the Wamego and De Soto sites. Median water temperatures and turbidities were about $17^{\circ} \mathrm{C}$ and $25 \mathrm{FNU}$ lower, respectively, and specific conductance was about 200 microsiemens per centimeter at $25^{\circ} \mathrm{C}$ higher during geosmin events than other time periods (table 5). When MIB concentrations were $>2 \mathrm{ng} / \mathrm{L}$, turbidity was significantly higher than when concentrations were $<2 \mathrm{ng} / \mathrm{L}$ at the De Soto site but not the Wamego site. MIB was significantly correlated with actinomycetes bacteria at the De Soto site, and higher turbidities when MIB was $>2 \mathrm{ng} / \mathrm{L}$ may be indicative of taste-and-odor events caused by runoff rather than cyanobacteria. Additional data collection during cyanobacteria- and runoff-driven taste-and-odor events is necessary for a better characterization of environmental factors associated with geosmin and MIB occurrence on the Kansas River.

\section{Logistic Regression Model Evaluation}

Continuous and discrete data collected at the Wamego and De Soto sites during July 2015 through September 2016 were used to evaluate previously developed logistic regression models that continuously estimate the probability of occurrence above selected thresholds for cyanobacteria, microcystin, and geosmin at the Wamego and De Soto sites (Foster and Graham, 2016). Ordinary least squares regression was not an appropriate approach for these constituents owing to a high percentage (10 to 70 percent depending on constituent; Foster and Graham, 2016) of discrete sample concentrations below the analytical detection limit (Helsel and Hirsch, 2002). The models were developed using discrete water-quality and continuous-sensor data collected during July 2012 through June 2015 (Foster and Graham, 2016). Models were considered suitable for estimating probability of occurrence if they accurately classified at least 65 percent of the sample data, including the highest measured concentrations for a given constituent (Foster and Graham, 2016). All models were developed to be conservative by guarding against false negatives when estimating the probability of exceeding a given threshold (Foster and Graham, 2016). Conservative models minimize the risk of missing a potential cyanobacterial, microcystin, or geosmin event in the Kansas River. Collection of model validation data, including discrete cyanobacteria, microcystin, and geosmin samples, was continued during July 2015 through September 2016. 


\section{Cyanobacteria Models}

The best fit multiple logistic regression models for cyanobacteria occurrence at concentrations $>2,000$ cells $/ \mathrm{mL}$ (Wamego site) and 10,000 cells/mL (De Soto site) included a seasonal component and turbidity as explanatory variables and accurately classified 80 and 91 percent of the samples used for model development at the Wamego $(n=56)$ and De Soto $(n=57)$ sites, respectively (Foster and Graham, 2016). As defined by Foster and Graham (2016), the TPPC used to classify samples during the validation period was 0.31 at the Wamego site and 0.48 at the De Soto site. During July 2015 through September 2016 these models accurately classified 71 and 79 percent of the validation samples at the Wamego $(n=24)$ and De Soto $(n=24)$ sites, respectively (figs. $9 A$, $B)$. The lack of detections above selected thresholds likely influenced overall model performance during the validation period. Although most validation samples were accurately classified, few detections exceeded the selected thresholds of interest for cyanobacteria at either site during the validation period (Wamego site: 5 of 24; De Soto site: 3 of 24). At the Wamego site, one of the detections above the threshold was incorrectly classified and at the De Soto site all three of the detections above the threshold were incorrectly classified (false negatives). Therefore, although the models accurately classified more than 65 percent of the validation samples at both sites, the De Soto model did not fulfill the model suitability criteria of classifying the highest measured concentrations.

Because turbidity is an explanatory variable in the cyanobacteria models at both sites, the change from the YSI 6136 turbidity sensor to the EXO turbidity sensor may have an influence on model performance. Overall influence of the change in turbidity sensor on performance likely is minimal because the models were developed using data from the YSI 6136 and EXO turbidity sensors and the difference between the two sensors was relatively small at $<200 \mathrm{FNU}$ (appendix figs. 5.1 to 5.6). About 90 percent of the sensor-measured turbidity data collected during July 2012 through September 2016 was $<200$ FNU (fig. 5D). An evaluation of model performance over a range of turbidity conditions at both sites indicated that turbidity has the most substantial influence on the models at turbidities between about 30 and 75 FNU (appendix figs. 6.1 and 6.2). About 60 percent of improperly classified validation samples at each site had turbidities within the 30 to 75 FNU range. Improper classification within this range likely was caused by how rapidly the estimated probability of exceedance changed rather than differences caused by the change in turbidity sensors.

\section{Microcystin Models}

The best fit multiple logistic regression models for microcystin occurrence at concentrations greater than the $0.1-\mu \mathrm{g} / \mathrm{L}$ detection threshold included a seasonal component, streamflow, and turbidity (Wamego site only) as explanatory variables and accurately classified 85 and 78 percent of the samples used for model development at the Wamego $(n=59)$ and De Soto $(n=60)$ sites, respectively (Foster and Graham, 2016). As defined by Foster and Graham (2016), the TPPC used to classify samples during the validation period was 0.40 at the Wamego site and 0.36 at the De Soto site. During July 2015 through September 2016 these models accurately classified 53 and 58 percent of the validation samples at the Wamego $(n=30)$ and De Soto $(n=31)$ sites, respectively (figs. $10 A, B$ ). The multiple logistic regression models for microcystin did not fulfill the model suitability criteria outlined in Foster and Graham (2016) during the validation period. However, there were few microcystin detections at either site in the validation dataset; 13 percent of samples had concentrations $\geq 0.1 \mu \mathrm{g} / \mathrm{L}$ during the validation period (Wamego site: 4 of 30; De Soto site: 4 of 31 ). In addition, the intended conservative nature of these models caused most of the inaccurate classifications to be false positives.

Because turbidity is an explanatory variable in the microcystin model at the Wamego site, the change from the YSI 6136 turbidity sensor to the EXO turbidity sensor may have an influence on model performance. Overall influence of the change in turbidity sensor on performance likely is minimal because the model was developed using data from the YSI 6136 and EXO turbidity sensors and the difference between the two sensors was relatively small at $<200 \mathrm{FNU}$ (appendix figs. 5.1 to 5.6). About 90 percent of the sensor-measured turbidity data collected during July 2012 through September 2016 was $<200$ FNU (fig. 5D). An evaluation of model performance over a range of turbidity conditions indicated that turbidity has the most substantial influence on the model during May through December at turbidities between 30 and 75 FNU (appendix fig. 6.3). About 38 percent of improperly classified validation samples had turbidities within the 30 to $75 \mathrm{FNU}$ range, and all improper classifications occurred during May through December. Even though the microcystin model for the De Soto site did not have turbidity as an explanatory variable, model performance at the two sites was similar. Most (82 percent) improper classifications at the De Soto site also occurred during May through December. Improper classification likely was caused by the conservative nature of the model rather than differences caused by the change in turbidity sensors.

\section{Geosmin Models}

The best fit multiple logistic regression models for geosmin occurrence at concentrations $>2.0 \mathrm{ng} / \mathrm{L}$ included a seasonal component, chlorophyll fluorescence (Wamego site), and streamflow (De Soto site) as explanatory variables and accurately classified 73 and 75 percent of the samples used for model development at the Wamego $(n=59)$ and De Soto ( $n=61)$ sites, respectively (Foster and Graham, 2016). As defined by Foster and Graham (2016), the TPPC used to classify samples during the validation period was 0.53 at the 


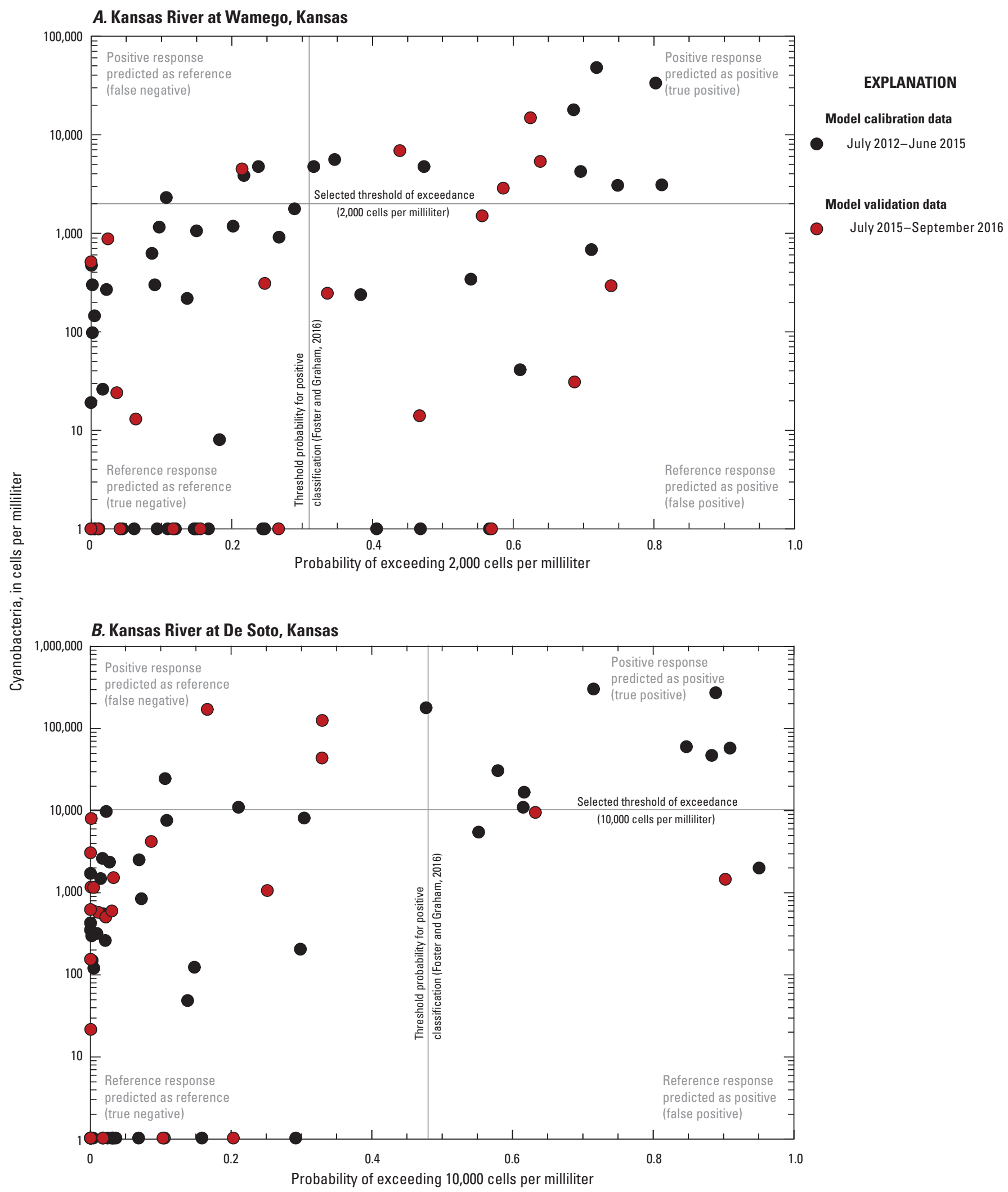

Figure 9. Performance of logistic regression models estimating the probability of cyanobacterial occurrence above thresholds of concern at sites on the Kansas River during July 2012 through September 2016. A, Kansas River at the Kansas River at Wamego, Kansas (U.S. Geological Survey station 06887500). B, Kansas River at De Soto, Kansas (U.S. Geological Survey station 06892350). 


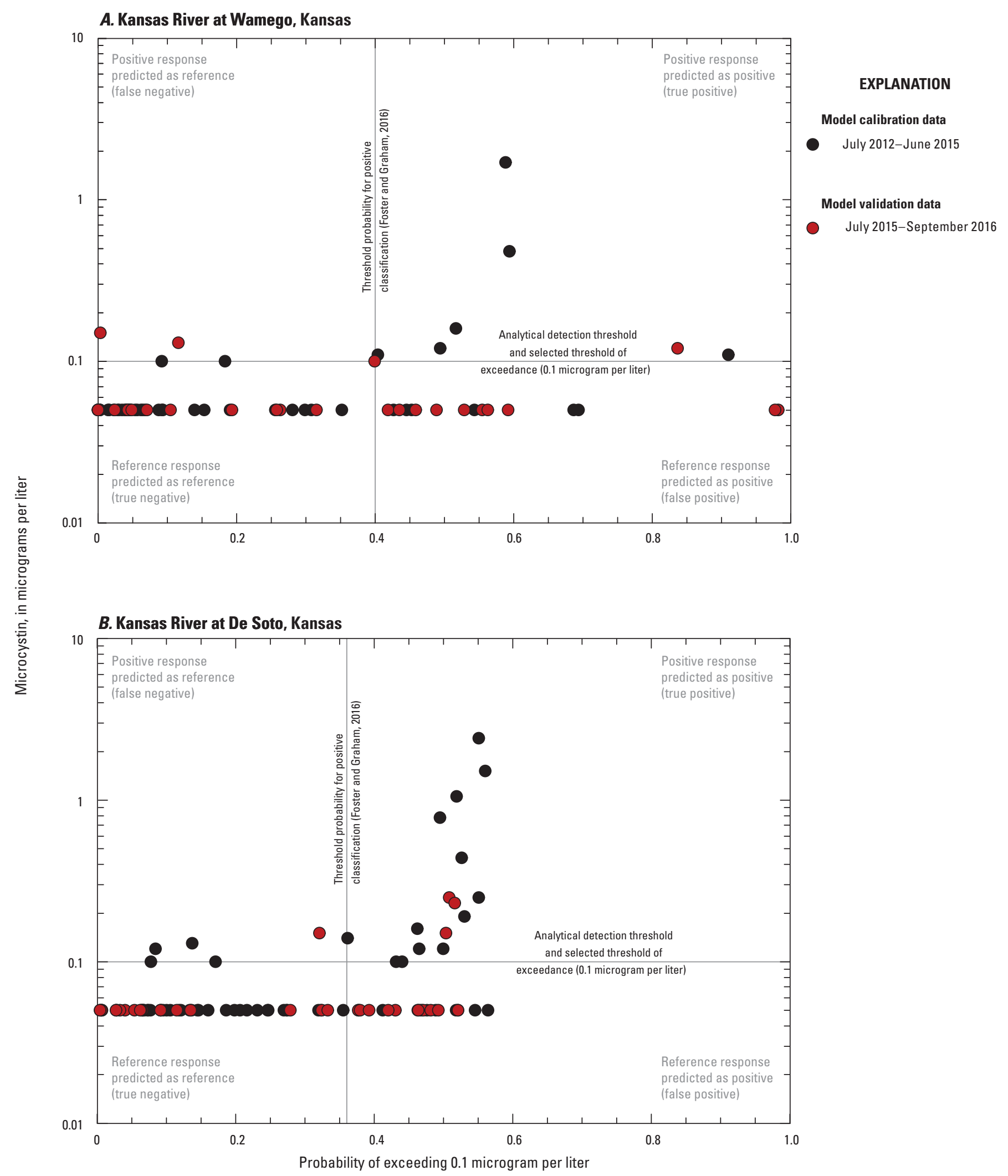

Figure 10. Performance of logistic regression models estimating the probability of microcystin occurrence above a threshold of concern at sites on the Kansas River during July 2012 through September 2016. A, Kansas River at the Kansas River at Wamego, Kansas (U.S. Geological Survey station 06887500). B, Kansas River at De Soto, Kansas (U.S. Geological Survey station 06892350). 
Wamego site and 0.50 at the De Soto site. During July 2015 through September 2016 these models accurately classified 80 and 84 percent of the validation samples at the Wamego $(n=30)$ and De Soto $(n=31)$ sites, respectively, including the highest measured concentrations (figs. 11A, B). Overall, the multiple logistic regression models for geosmin at the Wamego and De Soto sites continued to fulfill the model suitability criteria outlined in Foster and Graham (2016) during the validation period. Consistency in model performance may be due to the high number of detections during both time periods at both sites. In addition, several concentrations exceeded the selected threshold of interest of $2 \mathrm{ng} / \mathrm{L}$ at both sites during the validation period (Wamego site: 11 of 30; De Soto site: 13 of 31).

Because fChl is an explanatory variable in the geosmin model at the Wamego site, the change from the YSI $6025 \mathrm{fChl}$ sensor to the EXO fChl sensor may have an influence on model performance (appendixes 1 through 4). Given that the geosmin model at the Wamego site accurately classified more than 70 percent of validation samples, including the highest measured concentrations, the change in fChl sensors seems to have had a minimal influence on model performance. The change in sensors may have had minimal influence because the model was developed using data from the YSI 6025 and EXO fChl sensors. An evaluation of model performance over a range of fChl conditions indicated that fChl had the most substantial influence on the model performance during May through November and at concentrations between 11 and $22 \mu \mathrm{g} / \mathrm{L}$ (appendix fig. 6.4). About 17 percent of improperly classified validation samples had fChl values within the 11 to $22 \mu \mathrm{g} / \mathrm{L}$ range, and all occurred during May through November. Even though the geosmin model for the De Soto site did not have fChl as an explanatory variable, model performance at the two sites was similar. Most (67 percent) improper classifications at the De Soto site also occurred during May through November. Improper classifications during May through November likely occurred because of the seasonal influence on the models (for example, appendix fig. 6.4) rather than differences caused by the change in fChl sensors.

\section{Model Refinement}

Continued monitoring of underlying environmental conditions is essential for further model refinement and ongoing model evaluation. Erosional events, shifting stream channels, changes in reservoir management strategies, algal community composition, or other underlying factors that affect ecosystem structure and function could potentially affect model performance. For example, Cheney Reservoir, a primary drinkingwater supply in south-central Kansas, had a large inflow event during August 2013 that resulted in the reservoir gaining about 89,000 acre-feet in 10 days (Graham and others, 2017). Following this event, a previously published logistic model for geosmin occurrence above the selected threshold of $5 \mathrm{ng} / \mathrm{L}$ performed poorly, likely because of shifts in algal community composition. Continued data collection allowed identification of the model performance issue and the development of a new model (Graham and others, 2017).

Further refinement of the Kansas River models estimating the probability of occurrence of cyanobacteria, microcystin, and geosmin above relevant thresholds likely will increase model performance. However, additional data collected during cyanobacteria, microcystin, and taste-and-odor events are required. Few detections above selected thresholds of interest during the model validation period prevented refinement of models as part of this report.

Overall and individual reservoir contributions to total streamflow were significantly different during microcystin and geosmin events during July 2012 through September 2016. However, this methodology is currently (2018) limited to discrete time applications; it cannot be implemented on a continuous basis. Therefore, considering reservoir contribution as a potential explanatory variable in the logistic regression models that continuously estimate the probability of occurrence above selected thresholds for cyanobacteria, microcystin, and geosmin at the Wamego and De Soto sites is not currently feasible. Implementation of the methods used to determine overall and individual reservoir contributions to total streamflow on a continuous basis should be explored and would likely enhance model performance.

Model functionality could be enhanced by raising the thresholds of interest from 0.1 to $0.3 \mu \mathrm{g} / \mathrm{L}$ for microcystin and from 2 to $5 \mathrm{ng} / \mathrm{L}$ for geosmin. The higher microcystin threshold of $0.3 \mu \mathrm{g} / \mathrm{L}$ may be more relevant to water treatment owing to its importance as an EPA health advisory guidance threshold for finished drinking water (U.S. Environmental Protection Agency, 2015). Additionally, the higher geosmin threshold of interest of $5 \mathrm{ng} / \mathrm{L}$ may be more practical to water treatment because it is the concentration at which humans can begin to detect the taste-and-odor compound. Changing the thresholds of concern in the models would provide a more practical estimation of the probability of microcystin and geosmin occurrence in real-time to water-treatment managers that use the Kansas River as a source water supply; however, for the thresholds of interest to be changed, additional data need to be collected during microcystin and taste-and-odor events.

Continuous water-quality data may be used independently, or in combination with regression models, to provide information on changing water-quality conditions that may affect drinking-water treatment processes or recreational activities on the Kansas River. For example, logistic regression model outputs and continuous water-quality data may both be indicative of the potential for microcystin events. Logistic regression models that are estimating a high probability of microcystin occurrence at concentrations above $0.1 \mu \mathrm{g} / \mathrm{L}$ can be used as one indicator. Streamflows $<3,000 \mathrm{ft}^{3} / \mathrm{s}$ during upstream reservoir releases during periods with low turbidity and increased fChl, specific conductance, and $\mathrm{pH}$ values may also be indicative of microcystin events. Advanced or near-real-time notification may inform proactive, rather than reactive, management strategies when water-quality conditions are changing rapidly or are likely to cause cyanobacteria-related events. 


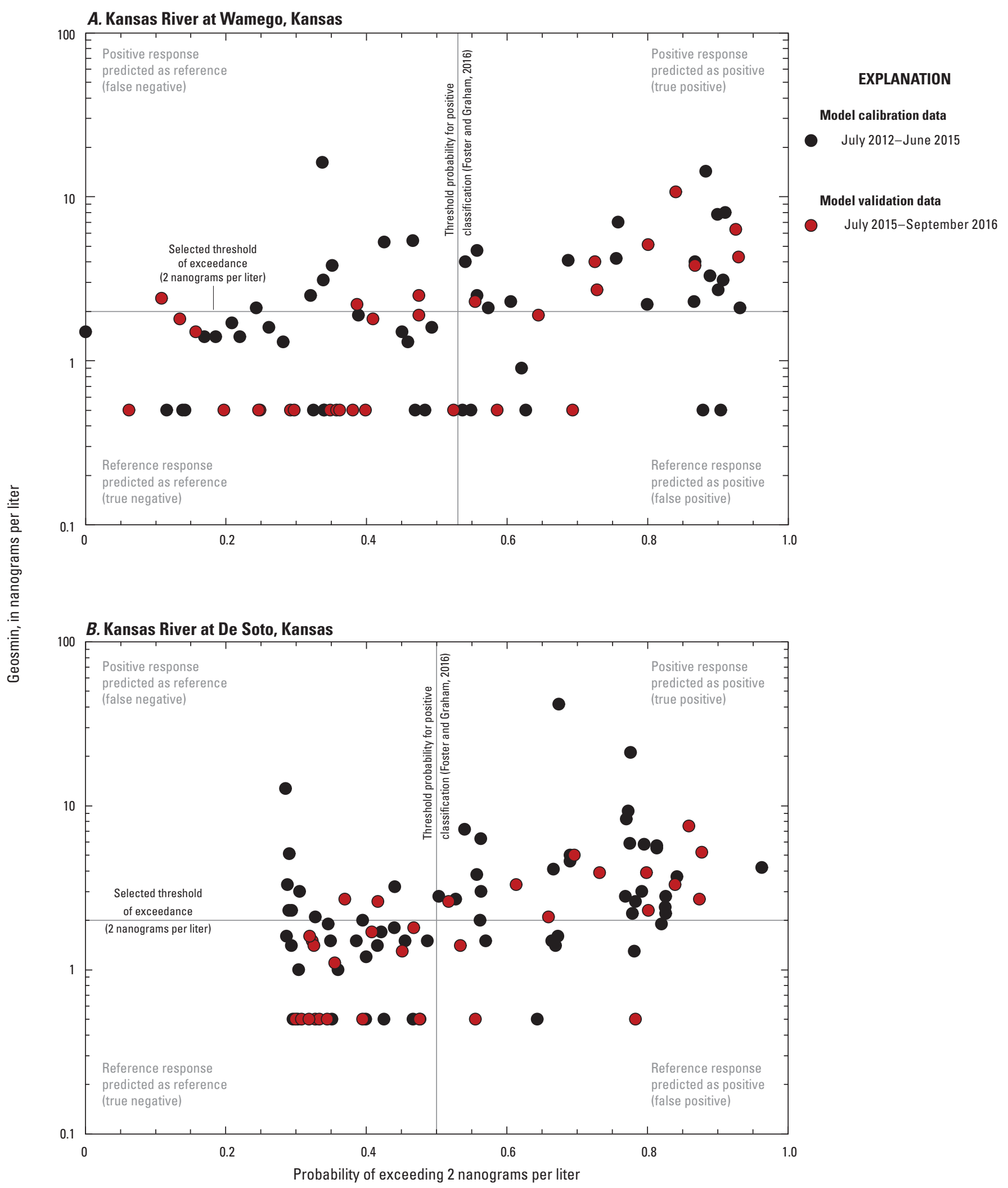

Figure 11. Performance of logistic regression models estimating the probability of geosmin occurrence above a threshold of concern at sites on the Kansas River during July 2012 through September 2016. A, Kansas River at the Kansas River at Wamego, Kansas (U.S. Geological Survey station 06887500). B, Kansas River at De Soto, Kansas (U.S. Geological Survey station 06892350). 


\section{Summary}

Cyanobacteria cause a multitude of water-quality concerns, including the potential to produce toxins and taste-andodor compounds. Toxins and taste-and-odor compounds may cause substantial economic and public health concerns and are of particular interest in lakes, reservoirs, and rivers that are used for drinking-water supply. The Kansas River and its associated alluvial aquifer are primary sources of drinking water for about 800,000 people in northeastern Kansas. Extensive cyanobacterial blooms typically do not develop in the Kansas River; however, reservoirs in the lower Kansas River Basin occasionally develop blooms that may affect downstream water quality. Since July 2012, the U.S. Geological Survey, in cooperation with the Kansas Water Office, the City of Lawrence, the City of Olathe, the City of Topeka, and Johnson County WaterOne, has collected discrete and continuously measured water-quality data at two sites on the Kansas River to better characterize the sources, frequency and magnitude of occurrence, and causes of cyanobacteria, cyanotoxins, and taste-and-odor compounds and to develop a real-time notification system of changing water-quality conditions that may affect drinking-water treatment. The purpose of this report is to (1) describe water-quality conditions, with an emphasis on cyanobacteria and associated toxins (microcystin) and taste-and-odor compounds (geosmin and 2-methylisoborneol [MIB]), in the Kansas River during July 2012 through September 2016; (2) describe the environmental factors associated with the occurrence of cyanobacteria and associated toxins and taste-and-odor compounds in the Kansas River during July 2012 through September 2016; and (3) evaluate previously published logistic regression models that used continuous water-quality data to estimate the probability of cyanobacteria, microcystin, and geosmin occurrence above relevant thresholds in the Kansas River. Quantification of cyanobacteria, cyanotoxins, and taste-and-odor compounds, and the conditions under which they are most likely to occur in the Kansas River will provide drinking-water suppliers and the State of Kansas a better understanding of associated water-quality concerns in the river. The logistic regression models evaluated in this report may provide useful indicators of cyanobacteria, microcystin, and geosmin occurrence in the Kansas River.

The U.S. Geological Survey collected continuous and discrete streamflow and water-quality data at two sites (Wamego and De Soto) on the Kansas River during July 2012 through September 2016. Continuous water-quality data included water temperature, $\mathrm{pH}$, dissolved oxygen, turbidity, specific conductance, and chlorophyll fluorescence. Discrete water-quality samples were collected approximately bimonthly during May through October and monthly during November through April. Discrete samples were analyzed for suspended-sediment concentration, dissolved solids and major ions, nutrients (nitrogen and phosphorus species), trace elements, indicator and actinomycetes bacteria, algal biomass, phytoplankton abundance and community composition, the cyanotoxins microcystin and cylindrospermopsin (July 2015 through September 2016 only), and the taste-and-odor compounds geosmin and MIB. Additionally, event-based discrete water-quality samples were collected at three reservoir outflow sites that are tributaries to the Kansas River: the Republican River (downstream from Milford Lake), the Big Blue River (downstream from Tuttle Creek Lake), and the Delaware River (downstream from Perry Lake). Event-based samples were analyzed for the cyanotoxins microcystin and cylindrospermopsin (July 2015 through September 2016 only) and the taste-and-odor compounds geosmin and MIB.

Streamflow at the upstream Wamego site was lower than streamflow at the downstream De Soto site across all years and seasons during the study period. Mean annual streamflows during 2012 through 2014 at the Wamego and De Soto sites were lower than mean annual streamflows during 2015 and 2016. Streamflows during 2012 through 2014 follow patterns expected during a period of drought, and patterns in 2015 and 2016 are indicative of nondrought streamflows. The Wamego site typically had a greater percentage of flow from upstream reservoirs than the De Soto site, despite De Soto having more contributing reservoirs. The highest annual streamflow contributions from reservoirs in the Kansas River were observed in 2012.

In general, differences in water temperature, $\mathrm{pH}$, dissolved oxygen, specific conductance, turbidity, and most discretely measured water-quality variables between the two Kansas River study sites were small. Observed seasonal and interannual patterns were typical and associated with characteristic changes in water temperature, streamflow, and biological processes. Differences in total nitrogen and phosphorus concentrations between the Wamego and De Soto sites were small. Seasonal mean nutrient concentrations were highest in spring and lowest during fall and winter. Mean annual total nutrient concentrations at both sites generally increased each year between 2012 and 2016. The observed seasonal and interannual patterns in total nutrient concentrations were associated with seasonal and annual increases in streamflows. Seasonal mean nitrate plus nitrite concentrations at the Wamego and De Soto sites were highest in spring. In contrast, orthophosphorus concentrations were lower in spring than other seasons at both sites. As observed for total nutrients, mean annual inorganic nutrient concentrations at both sites generally increased each year between 2012 and 2016.

Bacteria in the actinomycetes group may produce the taste-and-odor compounds geosmin and MIB. Mean actinomycetes concentration was higher at the De Soto site than the Wamego site. Seasonal mean actinomycetes concentrations were lower during winter than any other season. Actinomycetes concentrations were highest during spring at the Wamego and De Soto sites, though this pattern was inconsistent across years. Mean annual actinomycetes concentrations varied across years and did not display clear patterns. Transport of actinomycetes bacteria typically increases with increased streamflows, and concentrations in the Kansas river were positively correlated with streamflow. Other factors, such as time since last rainfall and runoff event, soil temperatures, and 
temporal variability of actinomycetes communities in soils, likely also influence transport of actinomycetes bacteria in the Kansas River.

Chlorophyll is commonly used as an estimate of algal biomass. Sensor-measured chlorophyll concentrations were consistently higher at the De Soto site than the Wamego site during the study period. Seasonal mean sensor-measured chlorophyll concentrations were highest in spring and summer (the growing season) and lowest during winter. Mean annual sensor-measured chlorophyll concentrations varied less across years than seasons, likely reflecting the influence of temperature on algal growth. Chlorophyll concentrations at the Wamego and De Soto sites were negatively correlated with streamflow and total and bioavailable (orthophosphorus and nitrate plus nitrite) nutrient concentrations. The negative association between chlorophyll and nutrients in the Kansas River likely is caused by the relatively strong positive association between nutrient concentrations and streamflows. Algal biomass at the De Soto site was always higher than at the Wamego site. Higher algal biomass at the De Soto site likely was caused by algal growth during downstream transport without major losses due to grazing by aquatic organisms or other processes. Although nutrients are of importance for algal growth, downstream transport often makes the influence of nutrients and other processes on algal biomass difficult to discern.

Algal communities in the Kansas River typically were dominated by diatoms. Cyanobacteria were relatively common in the Kansas River but rarely dominated the algal community. Cyanobacterial abundances typically were higher at the De Soto site than the Wamego site. Cyanobacterial abundances generally peaked in late summer or early fall (July through October), with smaller peaks occasionally observed in spring (April through May). Cyanobacteria may be a concern for drinking-water treatment at abundances of 20,000 cells per milliliter (cells $/ \mathrm{mL}$ ) or higher. Cyanobacterial abundance exceeded 20,000 cells $/ \mathrm{mL}$ in about 7 and 16 percent of the samples collected from the Wamego and De Soto sites, respectively. Exceedances typically occurred during summer months, though occasional exceedances were observed during spring and fall. Relations between cyanobacterial abundance and streamflow, turbidity, and nutrients in the Kansas River were similar to those for chlorophyll and total phytoplankton abundance, indicating the same processes that influence overall algal biomass and dynamics also are influencing cyanobacteria.

The cyanotoxin microcystin was detected in about 27 percent of the samples collected across all sites (main-stem and tributaries) during July 2012 through September 2016. Cylindrospermopsin was detected in one sample across all sites (main stem and tributaries) during July 2015 through September 2016. Microcystin occurrence and concentration were similar between the Wamego and De Soto sites during July 2012 through September 2016. Microcystin was detected in about 20 and 23 percent of the samples collected from the Wamego and De Soto sites, respectively.
Microcystin concentrations ranged from less than $(<) 0.1$ to 1.7 micrograms per liter $(\mu \mathrm{g} / \mathrm{L})$ at the Wamego site and $<0.1$ to $2.41 \mu \mathrm{g} / \mathrm{L}$ at the De Soto site (both site medians $<0.1 \mu \mathrm{g} / \mathrm{L}$ ). At the Wamego site, microcystin concentration exceeded the U.S. Environmental Protection Agency health advisory guidance values for finished drinking water of 0.3 and $1.6 \mu \mathrm{g} / \mathrm{L}$ in about 6 and 1 percent of the samples, respectively. Similarly, at the De Soto site, microcystin concentrations exceeded 0.3 and $1.6 \mu \mathrm{g} / \mathrm{L}$ in about 5 and 1 percent of the samples, respectively. These guidance values are for finished drinking water and are not directly applicable to observed environmental concentrations but do provide a benchmark for comparison. Seasonal patterns in microcystin occurrence were consistent between sites and among years. Microcystin was detected most often and had the highest concentrations during summer. Though seasonal patterns in microcystin occurrence were generally consistent, seasonal maxima varied by an order of magnitude across years.

Dissolved-phase cyanotoxins may persist for several days to weeks after the decline of a cyanobacterial population and may be more difficult to remove than particulate-bound cyanotoxins during drinking-water treatment processes. Dissolved microcystin represented between 6 and 100 percent of total microcystin concentrations. When total concentrations were greater than (>) $0.3 \mu \mathrm{g} / \mathrm{L}$ and dissolved concentrations were measured, dissolved microcystin represented between 6 and 21 percent of total concentrations. These data indicated that the dissolved phase infrequently dominated the microcystin pool in the Kansas River when total microcystin was above detectable levels.

The taste-and-odor compounds geosmin and MIB were detected in about 78 and 43 percent of samples, respectively, collected across all sites (main-stem and tributaries) during July 2012 through September 2016. Geosmin and MIB occurrence and concentration varied considerably between the Wamego and De Soto sites. Detection frequency of geosmin was higher at the De Soto site than the Wamego site, reflecting overall patterns in algal biomass and actinomycetes abundance. Geosmin was detected in about 67 percent of Wamego samples and 81 percent of De Soto samples. Geosmin concentrations at the Wamego and De Soto sites ranged from $<1$ to 16.2 nanograms per liter (ng/L) (median=1.9 ng/L) and $<1$ to $41.6 \mathrm{ng} / \mathrm{L}$ (median $=2.05 \mathrm{ng} / \mathrm{L}$ ), respectively. The human detection threshold of $5 \mathrm{ng} / \mathrm{L}$ was exceeded for geosmin in about 11 and 17 percent of the samples collected at the Wamego and De Soto sites, respectively. Geosmin was detected during all months of the year at both sites, and there were no clear seasonal patterns. MIB was detected less frequently in the Kansas River than geosmin and was observed in about 42 percent of Wamego samples and 33 percent of De Soto samples. MIB concentrations also were lower than geosmin concentrations, ranging from $<1$ to $10.7 \mathrm{ng} / \mathrm{L}$ at the Wamego site and $<1$ to $25.9 \mathrm{ng} / \mathrm{L}$ at the De Soto site (both site medians $=<1 \mathrm{ng} / \mathrm{L}$ ). Concentrations exceeded $5 \mathrm{ng} / \mathrm{L}$ in about 7 and 5 percent of samples from the Wamego and De Soto sites, respectively. As 
observed for geosmin, there were no clear seasonal patterns in MIB occurrence or concentration.

Like the cyanotoxins, dissolved-phase taste-and-odor compounds may be more difficult to remove than particulatebound taste-and-odor compounds during drinking-water treatment processes. Overall, dissolved geosmin and MIB represented between 0 and 100 percent of total concentrations (median $=0$ percent). When total concentrations were greater than or equal to $5 \mathrm{ng} / \mathrm{L}$, dissolved geosmin represented a larger portion of the total concentration (median $=65$ percent). Dissolved MIB still represented a small portion of the total concentration when concentrations were greater than or equal to $5 \mathrm{ng} / \mathrm{L}$. These data indicate that the dissolved phase may dominate the geosmin pool in the Kansas River when concentrations are high, potentially creating additional challenges for drinking-water treatment.

During July 2012 through September 2016, geosmin was detected more frequently in the Kansas River tributary and main-stem sites (78 percent of samples) than MIB (43 percent of samples) or microcystin (27 percent of samples). Overall, only 10 percent of samples analyzed for microcystin, geosmin, and MIB did not have detectable concentrations of at least one of these compounds. Microcystin and taste-andodor compounds (either geosmin, MIB, or both) co-occurred in 22 percent of samples. Therefore, though microcystin and taste-and-odor compounds can occasionally occur together, presence of one may not be indicative of presence of the other. Furthermore, sufficient warning for human health protection cannot be provided by the presence of odor alone.

There seems to be a connection between microcystin detections in the Kansas River and occurrence of microcystin in upstream reservoirs (and tributary streams). Microcystin concentrations $>0.3 \mu \mathrm{g} / \mathrm{L}$ may be likely during the summer when streamflow is $<3,000 \mathrm{ft}^{3} / \mathrm{s}$ and contributions from Milford Lake exceed about 30 percent of total flow in the Kansas River. Observed microcystin concentrations typically were higher at the De Soto site than the Wamego or tributary sites during 2012 through 2016, indicating cyanobacteria may continue to grow and produce microcystin once introduced to the Kansas River.

The spatial and temporal patterns in geosmin and MIB occurrence and concentration were more complex than microcystin. There were no clear connections between geosmin and MIB occurrence in the Kansas River and potential upstream reservoir (or tributary stream) sources. Likewise, there was not a clear relation between algal biomass, cyanobacteria, or actinomycetes bacteria and taste-and-odor events in the Kansas River. Geosmin and MIB were not strongly correlated with any continuously measured environmental variable at either Kansas River site. Additional data collection during cyanobacteria- and runoff-driven taste-and-odor events is necessary for a better characterization of environmental factors associated with geosmin and MIB occurrence on the Kansas River.

Continuous and discrete data collected at the Wamego and De Soto sites during July 2015 through September 2016 were used to evaluate previously developed logistic regression models that continuously estimate the probability of occurrence above selected thresholds for cyanobacteria, microcystin, and geosmin at the Wamego and De Soto sites. Models were considered suitable for estimating probability of occurrence if they accurately classified at least 65 percent of the sample data, including the highest measured concentrations for a given constituent. The best fit multiple logistic regression models for cyanobacteria occurrence at concentrations $>2,000$ cells $/ \mathrm{mL}$ (Wamego site) and 10,000 cells $/ \mathrm{mL}$ (De Soto site) included a seasonal component and turbidity as explanatory variables. Although the cyanobacteria occurrence models accurately classified more than 65 percent of the validation samples at both sites, the De Soto model did not fulfill the model suitability criteria of classifying the highest measured concentrations. The best fit multiple logistic regression models for microcystin occurrence at concentrations greater than the $0.1-\mu \mathrm{g} / \mathrm{L}$ detection threshold included a seasonal component, streamflow, and turbidity (Wamego site only) as explanatory variables. The best fit multiple logistic regression models for microcystin did not fulfill the model suitability criteria the validation period. However, there were few microcystin detections at either site in the validation dataset; 13 percent of samples had concentrations greater than or equal to $0.1 \mu \mathrm{g} / \mathrm{L}$ during the validation period. In addition, the intended conservative nature of these models caused most of the inaccurate classifications to be false positives. The best fit multiple logistic regression models for geosmin occurrence at concentrations $>2.0 \mathrm{ng} / \mathrm{L}$ included a seasonal component, chlorophyll fluorescence (Wamego site), and streamflow (De Soto site) as explanatory variables. The models for geosmin continued to fulfill the model suitability criteria during the validation period.

Continued monitoring of underlying environmental conditions is essential for further model refinement and ongoing model evaluation. Further refinement of the Kansas River models estimating the probability of occurrence of cyanobacteria, microcystin, and geosmin above relevant thresholds likely will increase model performance. However, additional data collected during cyanobacteria, microcystin and taste-and-odor events are required. Few detections above selected thresholds of interest during the model validation period prevented refinement of models as part of this report. Overall and individual reservoir contributions to total streamflow were significantly different during microcystin and geosmin events during July 2012 through September 2016. Implementation of the methods used to determine overall and individual reservoir contributions to total streamflow on a continuous basis should be explored and would likely enhance model performance. Model functionality could be enhanced by raising the thresholds of interest from 0.1 to $0.3 \mu \mathrm{g} / \mathrm{L}$ for microcystin and from 2 to $5 \mathrm{ng} / \mathrm{L}$ for geosmin. Changing the thresholds of concern in the models would provide a more practical estimation of the probability of microcystin and geosmin occurrence in real-time to watertreatment managers that use the Kansas River as a source water supply; however, for the thresholds of interest to be changed, additional data need to be collected during microcystin and taste-and-odor events. 
Continuous water-quality data may be used independently, or in combination with regression models, to provide information on changing water-quality conditions that may affect drinking-water treatment processes or recreational activities on the Kansas River. For example, logistic regression model outputs and continuous water-quality data may both be indicative of the potential for microcystin events. Logistic regression models that are estimating a high probability of microcystin occurrence at concentrations above $0.1 \mu \mathrm{g} / \mathrm{L}$ can be used as one indicator. Streamflows $<3,000 \mathrm{ft}^{3} / \mathrm{s}$ during upstream reservoir releases during periods with low turbidity and increased chlorophyll fluorescence, specific conductance, and $\mathrm{pH}$ values may also be indicative of microcystin events. Advanced or near-real-time notification may inform proactive, rather than reactive, management strategies when water-quality conditions are changing rapidly or are likely to cause cyanobacteriarelated events.

\section{References Cited}

Allan, J.D., and Castillo, M.M., 2007, Stream ecology: Structure and Function of Running Waters ( $2 \mathrm{~d}$ ed.): Dordrecht, The Netherlands, Springer, 436 p. [Also available at https:// doi.org/10.1007/978-1-4020-5583-6.]

Arar, E.J., and Collins, G.B., 1997, Method 445.0 - In vitro determination of chlorophyll a and pheophytin a in marine and freshwater algae by fluorescence (rev. 1.2). U.S. Environmental Protection Agency, Office of Research and Development, $22 \mathrm{p}$.

Archfield, S.A., Kennen, J.G., Carlisle, D.M., and Wolock, D.M., 2014, An objective and parsimonious approach for classifying natural flow regimes at a continental scale: River Research and Applications, v. 30, no. 9, p. 1166-1183. [Also available at https://doi.org/10.1002/rra.2710.]

Bennett, T.J., Graham, J.L., Foster, G.M., Stone, M.L., Juracek, K.E., Rasmussen, T.J., and Putnam, J.E., 2014, U.S. Geological Survey quality-assurance plan for continuous water-quality monitoring in Kansas, 2014: U.S. Geological Survey Open-File Report 2014-1151, 34 p. plus appendixes. [Also available at https://dx.doi.org/10.3133/ofr20141151.]

Camargo, J.A., and Alonso, Á., 2006, Ecological and toxicological effects of inorganic nitrogen pollution in aquatic ecosystems - A global assessment: Environment International, v. 32, no. 6, p. 831-849. [Also available at https:// doi.org/10.1016/j.envint.2006.05.002.]
Chiswell, R.K., Shaw, G.R., Eaglesham, G.K., Smith, M.J., Norris, R.L., Seawright, A.A., and Moore, M.R., 1999, Stability of cylindrospermopsin, the toxin from the Cyanobacterium, Cylindrospermopsis raciborskii-Effect of $\mathrm{pH}$, temperature, and sunlight on decomposition: Environmental Toxicology, v. 14, no. 1, p. 155-161. [Also available at https://doi.org/10.1002/(SICI)15227278(199902)14:1<155::AID-TOX20>3.0.CO;2-Z.]

Chorus, I., and Bartram, J., 1999, Toxic cyanobacteria in water-A Guide to public health significance, monitoring and management - World Health Organization, E \& FN Spon: London, Chapman \& Hall, 416 p. [Also available at https://www.who.int/water_sanitation_health/resourcesquality/toxcyanbegin.pdf.]

Corsi, S.R., Graczyk, D.J., Geis, S.W., Booth, N.L., and Richards, K.D., 2010, A fresh look at road salt-Aquatic toxicity and water-quality impacts on local, regional, and national scales: Environmental Science \& Technology, v. 44, no. 19, p. 7376-7382. [Also available at https://doi.org/10.1021/ es101333u.]

Dodds, W.K., Jones, J.R., and Welch, E.B., 1998, Suggested classification of stream trophic state-Distributions of temperate stream types by chlorophyll, total nitrogen, and phosphorus: Water Research, v. 32, p. 1455-1462.

Eaton, A.D., Clesceri, L.S., Rice, E.W., Greenberg, A.E., and Franson, M.A.H, 2005, Standard methods for examination of water and wastewater (21st ed.): Washington, D.C., American Public Health Association, 1368 p.

Fischer, W.J., Garthwaite, I., Miles, C.O., Ross, K.M., Aggen, J.B., Chamberlin, A.R., Towers, N.R., and Dietrich, D.R., 2001, Congener independent immunoassay for microcystins and nodularins: Environmental Science \& Technology, v. 35, no. 24, p. 4849-4856. [Also available at https://doi. org/10.1021/es011182f.]

Fishman, M.J., and Friedman, L.C., 1989, Methods for determination of inorganic substances in water and fluvial sediments: U.S. Geological Survey Techniques of WaterResources Investigations, book 5, chap. A1, 545 p.

Foster, G.M., and Graham, J.L., 2016, Logistic and linear regression model documentation for statistical relations between continuous real-time and discrete water-quality constituents in the Kansas River, Kansas, July 2012 through June 2015: U.S. Geological Survey Open-File Report 20161040, 27 p. [Also available at https://dx.doi.org/10.3133/ ofr20161040.]

Foster, G.M., Graham, J.L., Stiles, T.C., Boyer, M.G., King, L.R., and Loftin, K.A., 2017, Spatial variability of harmful algal blooms in Milford Lake, Kansas, July and August 2015: U.S. Geological Survey Scientific Investigations Report 2016-5168, 45 p. [Also available at https://doi. org/10.3133/sir20165168.] 
Francy, D.S., Graham, J.L., Stelzer, E.A., Ecker, C.D., and Brady, A.M.G., Struffolino, P., and Loftin, K.A., 2015, Water quality, cyanobacteria, and environmental factors and their relations to microcystin concentrations for use in predictive models at Ohio Lake Erie and inland lake recreational sites, 2013-14: U.S. Geological Survey Scientific Investigations Report 2015-5120, 58 p. [Also available at https://dx.doi.org/10.3133/sir20155120.]

Fry, J., Xian, G., Jin, S., Dewitz, J., Homer, C., Yang, L., Barnes, C., Herold, N., and Wickham, J., 2011, Completion of the 2006 National Land Cover Database for the conterminous United States: Photogrammetric Engineering and Remote Sensing, v. 77, no. 9, p. 858-864.

Graham, J.L., Dubrovsky, N.M., and Eberts, S.M., 2016, Cyanobacterial harmful algal blooms and U.S. Geological Survey science capabilities: U.S. Geological Survey OpenFile Report 2016-1174, 12 p. [Also available at https://doi. org/10.3133/ofr20161174.]

Graham, J.L., Foster, G.M., Williams, T.J., Kramer, A.R., and Harris, T.D., 2017, Occurrence of cyanobacteria, microcystin, and taste-and-odor compounds in Cheney Reservoir, Kansas, 2001-16: U.S. Geological Survey Scientific Investigations Report 2017-5016, 57 p. [Also available at https:// doi.org/10.3133/sir20175016.]

Graham, J.L., Loftin, K.A., Meyer, M.T., and Ziegler, A.C., 2010, Cyanotoxin mixtures and taste-and-odor compounds in cyanobacterial blooms from the midwestern United States: Environmental Science \& Technology, v. 44, no. 19, p. 7361-7368. [Also available at https://doi.org/10.1021/ es1008938.]

Graham, J.L., Loftin, K.A., Ziegler, A.C., and Meyer, M.T., 2008, Cyanobacteria in lakes and reservoirs - Toxin and taste-and-odor sampling guidelines (ver. 1.0): U.S. Geological Survey Techniques of Water-Resources Investigations, book 9, chap. A7, section 7.5, accessed April 2012 at https:// pubs.water.usgs.gov/twri9A/.

Graham, J.L., Ziegler, A.C., Loving, B.L., and Loftin, K.A., 2012, Fate and transport of cyanobacteria and associated toxins and taste-and-odor compounds from upstream reservoir releases in the Kansas River, Kansas, September and October 2011: U.S. Geological Survey Scientific Investigations Report 2012-5129, 65 p.

Guy, H.P., 1969, Laboratory theory and methods for sediment analysis: U.S. Geological Survey Techniques of WaterResources Investigations, book 5, chap. C1, 58 p.

Hambrook Berkman, J.A., and Canova, M.G., 2007, Algal biomass indicators (ver. 1.0): U.S. Geological Survey Techniques of Water-Resources Investigations, book 9, chap. A7, section 7.4, accessed October 20, 2017, at https://pubs. water.usgs.gov/twri9A/.
Helsel, D.R., 2005, Nondetects and data analysis - Statistics for censored environmental data: Hoboken, New Jersey, John Wiley \& Sons, 250 p.

Helsel, D.R., and Hirsch, R.M., 2002, Statistical methods in water resources-Hydrologic analysis and interpretation: U.S. Geological Survey Techniques of Water-Resources Investigations, book 4, chap. A3, 510 .

Hem, J.D., 1992, Study and interpretation of chemical characteristics of natural water ( $3 \mathrm{~d}$ ed.): U.S. Geological Survey Water-Supply Paper 2254, 263 p.

Heresztyn, T., and Nicholson, B.C., 1997, Nodularin concentrations in Lakes Alexandrina and Albert, South Australia, during a bloom of the cyanobacterium (blue-green alga) Nodularia spumigena and degradation of the toxin: Environmental Toxicology and Water Quality, v. 12, no. 4, p. 273282. [Also available at https://doi.org/10.1002/(SICI)10982256(1997)12:4<273::AID-TOX1>3.0.CO;2-5.]

Hudnell, H.K., ed., 2008, Cyanobacterial harmful algal blooms - State of the Science and Research Needs: Advances in Experimental Medicine and Biology, v. 619, $950 \mathrm{p}$.

Jones, G.J., and Orr, P.T., 1994, Release and degradation of microcystin following algicide treatment of a Microcystis aeruginosa bloom in a recreational lake, as determined by HPLC and protein phosphatase inhibition assay: Water Research, v. 28, no. 4, p. 871-876. [Also available at https:// doi.org/10.1016/0043-1354(94)90093-0.]

Kann, J., Bowater, L., and Corum, S., 2010, Middle Klamath River toxic cyanobacteria trends, 2009: Aquatic Ecosystem Sciences LLC Technical Memorandum, 34 p.

Kansas Department of Health and Environment, 2004, Surface water nutrient reduction plan: Topeka, Kansas, Bureau of Water, $47 \mathrm{p}$.

Kansas Department of Health and Environment, 2011, KansasLower Republican Basin total maximum daily load.

Kansas Department of Health and Environment, 2015, Kansas Surface Water Quality Standards-Tables of numeric criteria.

Knowlton, M.F., 1984, Flow-through microcuvette for fluorometric determination of chlorophyll: Water Resources Bulletin, v. 20, no. 5, p. 795-799. [Also available at https:// doi.org/10.1111/j.1752-1688.1984.tb04763.x.]

Kramer, A.L., Williams, T.J., and Mahoney, M.D., 2018, Phytoplankton data for the Kansas River and tributaries, July 2012 through February 2017: U.S. Geological Survey data release, accessed July 2018 at https://doi.org/10.5066/ P9EVITTP. 
Loftin, K.A., Graham, J.L., Hilborn, E.D., Lehmann, S.C., Meyer, M.T., Dietze, J.E., and Griffith, C.B., 2016, 2016, Cyanotoxins in inland lakes of the United States-Occurrence and potential recreational health risks in the EPA National Lakes Assessment 2007: Harmful Algae, v. 56, p. 77-90. [Also available at https://dx.doi.org/10.1016/j. hal.2016.04.001.].

Loftin, K.A., Meyer, M.T., Rubio, F., Kamp, L., Humphries, E., and Whereat, E., 2008, Comparison of two cell lysis procedures for recovery of microcystins in water samples from Silver Lake in Dover, Delaware, with microcystin producing cyanobacterial accumulations: U.S. Geological Survey Open-File Report 2008-1341, 9 p.

Meriluoto, J., Spoof, L., and Codd, G.A., 2017, Handbook of cyanobacterial monitoring and cyanotoxin analysis: Chichester, West Sussex, United Kingdom, John Wiley and Sons, $548 \mathrm{p}$.

Mueller, D.K., Schertz, T.L., Martin, J.D., and Sandstrom, M.W., 2015, Design, analysis, and interpretation of field quality-control data for water-sampling projects: U.S. Geological Survey Techniques and Methods, book 4, chap. C4, 54 p., [Also available at https://dx.doi.org/10.3133/tm4C4.]

Myers, D.N., Stoeckel, D.M., Bushon, R.N., Francy, D.S., and Brady, A.M.G., 2014, Fecal indicator bacteria (ver. 2.1): U.S. Geological Survey Techniques of Water-Resources Investigations, book 9, chap. A7, section 7.1. [Also available at https://pubs.water.usgs.gov/twri9A/.]

Otten, T.G., Crosswell, J.R., Mackey, S., and Dreher, T.W., 2015, Application of molecular tools for microbial source tracking and public health risk assessment of a Microcystis bloom traversing $300 \mathrm{~km}$ of the Klamath River: Harmful Algae, v. 46, p. 71-81. [Also available at https://doi. org/10.1016/j.hal.2015.05.007.]

Otten, T.G., Graham, J.L., Harris, T.D., and Dreher, T.W., 2016, Elucidation of taste- and odor-producing bacteria and toxigenic cyanobacteria in a Midwestern drinking water supply reservoir by shotgun metagenomic analysis: Applied and Environmental Microbiology, v. 82, no. 17, p. 5410-5420. [Also available at https://doi.org/10.1128/ AEM.01334-16.]

Perry, C.A., 1994, Solar-irradiance variations and regional precipitations in the western United States: International Journal of Climatology, v. 14, no. 9, p. 969-983.

Poff, N.L., Allan, J.D., Bain, M.B., Karr, J.R., Prestegaard, K.L., Richter, B., Sparks, R., and Stromberg, J., 1997, The natural flow regime-A new paradigm for riverine conservation and restoration: Bioscience, v. 47, no. 11, p. 769784. [Also available at https://doi.org/10.2307/1313099.]
Poff, N.L., and Zimmerman, J.K.H., 2010, Ecological responses to altered flow regimes-A literature review to inform the science and management of environmental flows: Freshwater Biology, v. 55, no. 1, p. 194-205. [Also available at https://doi.org/10.1111/j.1365-2427.2009.02272.x.]

Rasmussen, T.J., Ziegler, A.C., and Rasmussen, P.P., 2005, Estimation of constituent concentrations, densities, loads, and yields in lower Kansas River, northeast Kansas, using regression models and continuous water-quality monitoring, January 2000 through December 2003: U.S. Geological Survey Scientific Investigations Report 2005-5165, 117 p.

Rasmussen, P.P., and Christensen, V.G., 2005, Hydrologic and water-quality conditions in the Kansas River, northeast Kansas, November 2001-August 2002, and simulation of ammonia assimilative capacity and bacteria transport during low flow, 2005: U.S. Geological Survey Scientific Investigations Report 2005-5188, 111 p.

Reynolds, C.S., 1984, The ecology of freshwater phytoplankton: Cambridge, Cambridge University Press, 384 p.

Rice, E.W., Baird, R.B., Eaton, A.D., Clesceri, L.S., 2012, Detection of Actinomycetes, part 9250 of Standard methods for examination of water and wastewater (22 ed.): American Public Health Association, 1496 p.

Rounds, S.A., Carpenter, K.D., Fesler, K.J., and Dorsey, J.L., 2015, Upstream factors affecting Tualatin River algaeTracking the 2008 Anabaena algae bloom to Wapato Lake, Oregon: U.S. Geological Survey Scientific Investigations Report 2015-5178, 41 p. [Also available at https://dx.doi. org/10.3133/sir20155178.]

Sartory, D.P., and Grobbelaar, J.U., 1984, Extraction of chlorophyll a from freshwater phytoplankton for spectrophotometric analysis: Hydrobiologia, v. 114, no. 3, p. 177-187. [Also available at https://doi.org/10.1007/BF00031869.]

Sauer, V.B., and Turnipseed, D.P., 2010, Stage measurement at gaging stations: U.S. Geological Survey Techniques and Methods, book 3, chap. A7, 45 p. [Also available at https:// pubs.usgs.gov/tm/tm3-a 7/.]

Søballe, D.M., and Kimmel, B.L., 1987, A large-scale comparison of factors influencing phytoplankton abundance in rivers, lakes, and impoundments: Ecology, v. 68, no. 6, p. 1943-1954. [Also available at https://doi. org/10.2307/1939885.]

Taylor, W.D., Losee, R.F., Torobin, M., Izaguirre, G., Sass, D., Khiari, D., and Atasi, K., 2005, Early warning and management of surface water taste-and-odor events: American Water Works Association Research Foundation, 373 p.

The National Drought Mitigation Center, 2018, United States Drought Monitor: accessed May 10, 2018, at http://droughtmonitor.unl.edu/. 
Thornton, K.W., Kimmel, B.L., and Payne, F.E., eds., 1990, Reservoir limnology-ecological perspectives: New York, John Wiley \& Sons, 246 p.

Trevino-Garrison, I., DeMent, J., Ahmed, F.S., Haines-Lieber, P., Langer, T., Ménager, H., Neff, J., van der Merwe, D., and Carney, E., 2015, Human illnesses and animal deaths associated with freshwater harmful algal blooms - Kansas: Toxins, v. 7, no. 2, p. 353-366. [Also available at https:// doi.org/10.3390/toxins7020353.]

Turnipseed, D.P., and Sauer, V.B., 2010, Discharge measurements at gaging stations: U.S. Geological Survey Techniques and Methods, book 3, chap. A8, 87 p. [Also available at https://pubs.usgs.gov/tm/tm3-a8/.]

U.S. Army Corps of Engineers, 2017, Kansas City district lakes: accessed September 16, 2017, at https://www.nwk. usace.army.mil/Locations.

U.S. Environmental Protection Agency, 1986, Quality criteria for water: U.S. Environmental Protection Agency, EPA 440/5-86-001, accessed October 2017 at https://nepis.epa.gov//Exe/ZyPDF.cgi/00001MGA. PDF?Dockey $=00001 \mathrm{MGA}$. PDF.

U.S. Environmental Protection Agency, 2000, Ambient water quality criteria recommendations; Rivers and streams in Nutrient Ecoregion IX: U.S. Environmental Protection Agency, EPA 822-B-00-019, accessed October 2017 at https://www.epa.gov/sites/production/files/documents/rivers9.pdf.

U.S. Environmental Protection Agency, 2001, Ambient water quality criteria tecommendations; Rivers and streams in Nutrient Ecoregion IV: U.S. Environmental Protection Agency, EPA 822-B-01-013, accessed October 2017 at https://www.epa.gov/sites/production/files/documents/rivers4.pdf.

U.S. Environmental Protection Agency, 2009, National primary drinking water regulations: U.S. Environmental Protection Agency, EPA 816-F-09-004, accessed October 2017 at https:/www.epa.gov/sites/production/files/2016-06/ documents/npwdr_complete_table.pdf.

U.S. Environmental Protection Agency, 2013, Aquatic life ambient water quality criteria for ammonia-Freshwater: U.S. Environmental Protection Agency, EPA 822-R-13001, accessed October 2017 at https://www.epa.gov/sites/ production/files/2015-08/documents/aquatic-life-ambientwater-quality-criteria-for-ammonia-freshwater-2013.pdf.

U.S. Environmental Protection Agency, 2015, Recommendations for public water systems to manage cyanotoxins in drinking water: U.S. Environmental Protection Agency, EPA 815-R-15-010, accessed September 2016 at https:// www.epa.gov/sites/production/files/2017-06/documents/ cyanotoxin-management-drinking-water.pdf.
U.S. Geological Survey, 2006, Collection of water samples (ver. 2.0): U.S. Geological Survey Techniques of WaterResources Investigations, book 9, chap. A4 [variously paged]. [Also available at https://pubs.water.usgs.gov/ twri9A4/.]

U.S. Geological Survey, 2018, National Water Information System-Web interface: accessed January 2017 at https:// doi.org/10.5066/F7P55KJN.

Wagner, R.J., Boulger, R.W., Jr., Oblinger, C.J., and Smith, B.A., 2006, Guidelines and standard procedures for continuous water-quality monitors - Station operation, record computation, and data reporting: U.S. Geological Survey Techniques and Methods, book 1, chap. D3, 51 p. plus 8 attachments, accessed April 10, 2006, at https://pubs.water. usgs.gov/tm1d3.

Wehr, J.D., and Sheath, R.G., eds., 2003, Freshwater algae of North America-Ecology and classification: San Diego, California, Academic Press, 918 p.

Westrick, J.A., Szlag, D.C., Southwell, B.J., and Sinclair, J.L., 2010, A review of cyanobacteria and cyanotoxins removal/ inactivation in drinking water treatment: Analytical and Bioanalytical Chemistry, v. 397, no. 5, p. 1705-1714. [Also available at https://doi.org/10.1007/s00216-010-3709-5.]

Wetzel, R.G., 2001, Limnology (3d ed.): San Diego, Academic Press, $1,006 \mathrm{p}$.

Wilde, F.D., ed., 2008, Field measurements, in National field manual for the collection of water-quality data: U.S. Geological Survey Techniques of Water-Resources Investigations, book 9, chap. A6, p. 3-20.

Williams, G.P., and Wolman, M.G., 1984, Downstream effects of dams on alluvial rivers: U.S. Geological Survey Professional Paper 1286, 83 p.

Williams, T.J., Mahoney, M.D., and Kramer, A.L., 2018, Discrete water-quality data from the Kansas River and tributaries, July 2012-September 2016: U.S. Geological Survey data release, accessed July 2018 at https://doi.org/10.5066/ P973V4A9.

Yellow Springs Instruments (YSI), 2012, EXO water quality field sensors-Features, specifications, and comparability to YSI 6-Series sensors: YSI, revision B, 14 p., accessed September 15, 2017, at https://www.exowater.com/media/ pdfs/EXO-6Series-Sensor-Comparison.pdf.

Zaitlin, B., and Watson, S.B., 2006, Actinomycetes in relation to taste and odour in drinking water-Myths, tenets, and truths: Water Research, v. 40, no. 9, p. 1741-1753. [Also available at https://doi.org/10.1016/j.watres.2006.02.024.] 
Zaitlin, B., Watson, S.B., Ridal, J., Satchwill, T., and Parkinson, D., 2003, Actinomycetes in Lake Ontario-Habitats and geosmin and MIB production: Journal of the American Water Works Association, v. 95, no. 2, p. 113-118.

Zar, J.H., 1999, Biostatistical analysis (4th ed.): New Jersey, Prentice-Hall Inc., 663 p.

Zimmerman, L.R., Ziegler, A.C., and Thurman, E.M., 2002, Method of analysis and quality-assurance practices by U.S. Geological Survey Organic Geochemistry Research Group-Determination of geosmin and methylisoborneol in water using solid-phase microextraction and gas chromatography/mass spectrometry: U.S. Geological Survey OpenFile Report 02-337, 12 p. 
Table 2 
Table 2. Seasonal and annual means for discretely collected and continuously measured water-quality constituents at the Kansas River at Wamego, Kansas, and Kansas River at De Soto, Kansas, streamgages (U.S. Geological Survey stations 06887500 and 06892350 , respectively) during July 2012 through September 2016.

[winter, January through March; spring, April through June; summer, July through September; fall, October through December; ${ }^{\circ} \mathrm{C}$, degrees Celsius; --, no data; $\mathrm{mg} / \mathrm{L}$, milligram per liter; FNU, formazin nephelometric unit; $\mu \mathrm{s} / \mathrm{cm}$, microsiemen per centimeter at $25^{\circ} \mathrm{C}$; *, indicates that the mean value was calculated using one or more censored values (less than the minimum reporting limit), and censored values were substituted with a value one-half of the minimum reporting limit; CFU/100 mL, colony forming unit per 100 milliliters; colonies $/ \mathrm{mL}$, colonies per milliliter; $\mu \mathrm{g} / \mathrm{L}$, microgram per liter]

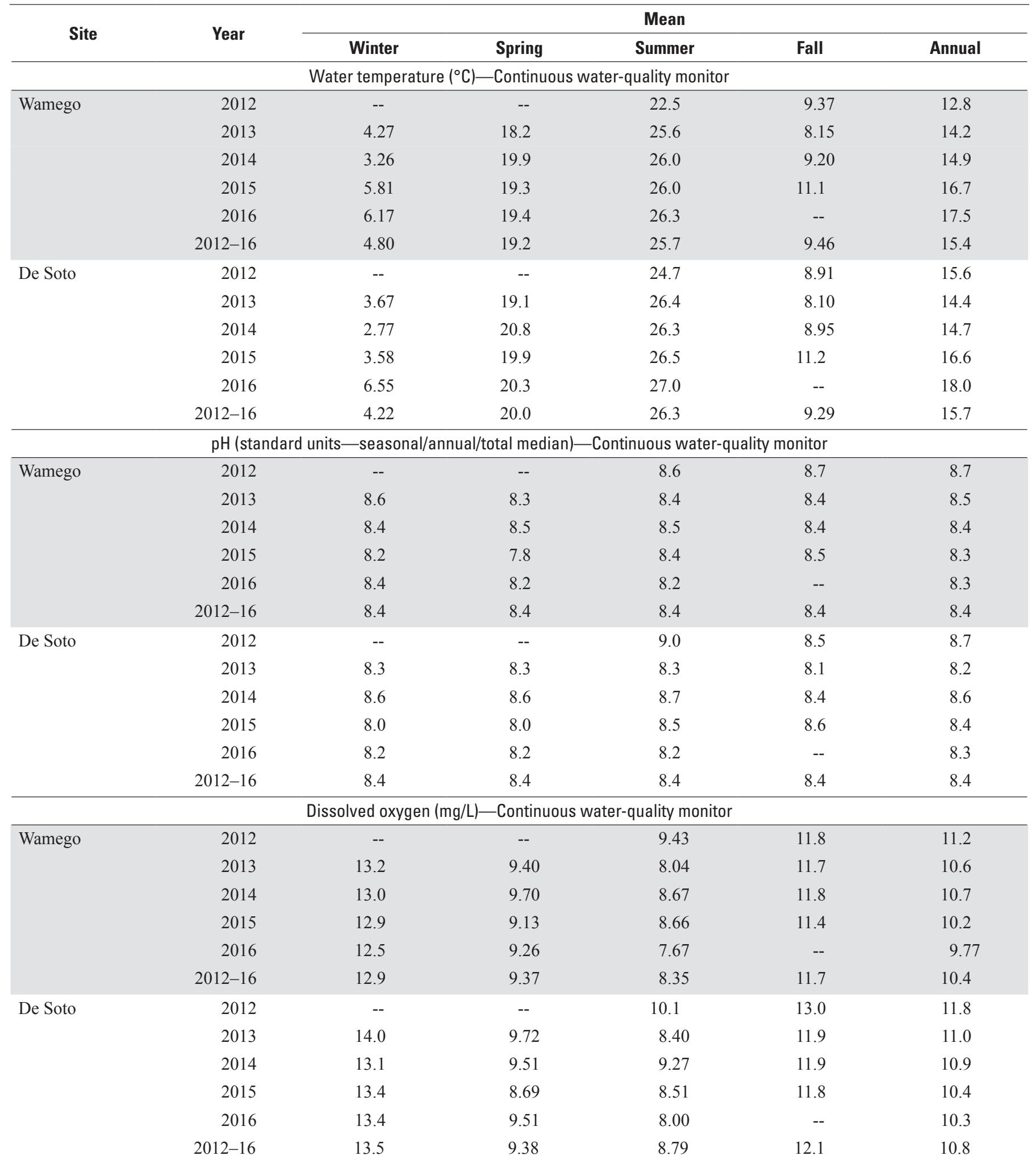


Table 2. Seasonal and annual means for discretely collected and continuously measured water-quality constituents at the Kansas River at Wamego, Kansas, and Kansas River at De Soto, Kansas, streamgages (U.S. Geological Survey stations 06887500 and 06892350 , respectively) during July 2012 through September 2016.-Continued

[winter, January through March; spring, April through June; summer, July through September; fall, October through December; ${ }^{\circ} \mathrm{C}$, degrees Celsius; --, no data; $\mathrm{mg} / \mathrm{L}$, milligram per liter; FNU, formazin nephelometric unit; $\mu \mathrm{s} / \mathrm{cm}$, microsiemen per centimeter at $25^{\circ} \mathrm{C}$; ${ }^{*}$, indicates that the mean value was calculated using one or more censored values (less than the minimum reporting limit), and censored values were substituted with a value one-half of the minimum reporting limit; CFU/100 mL, colony forming unit per 100 milliliters; colonies/mL, colonies per milliliter; $\mu \mathrm{g} / \mathrm{L}$, microgram per liter]

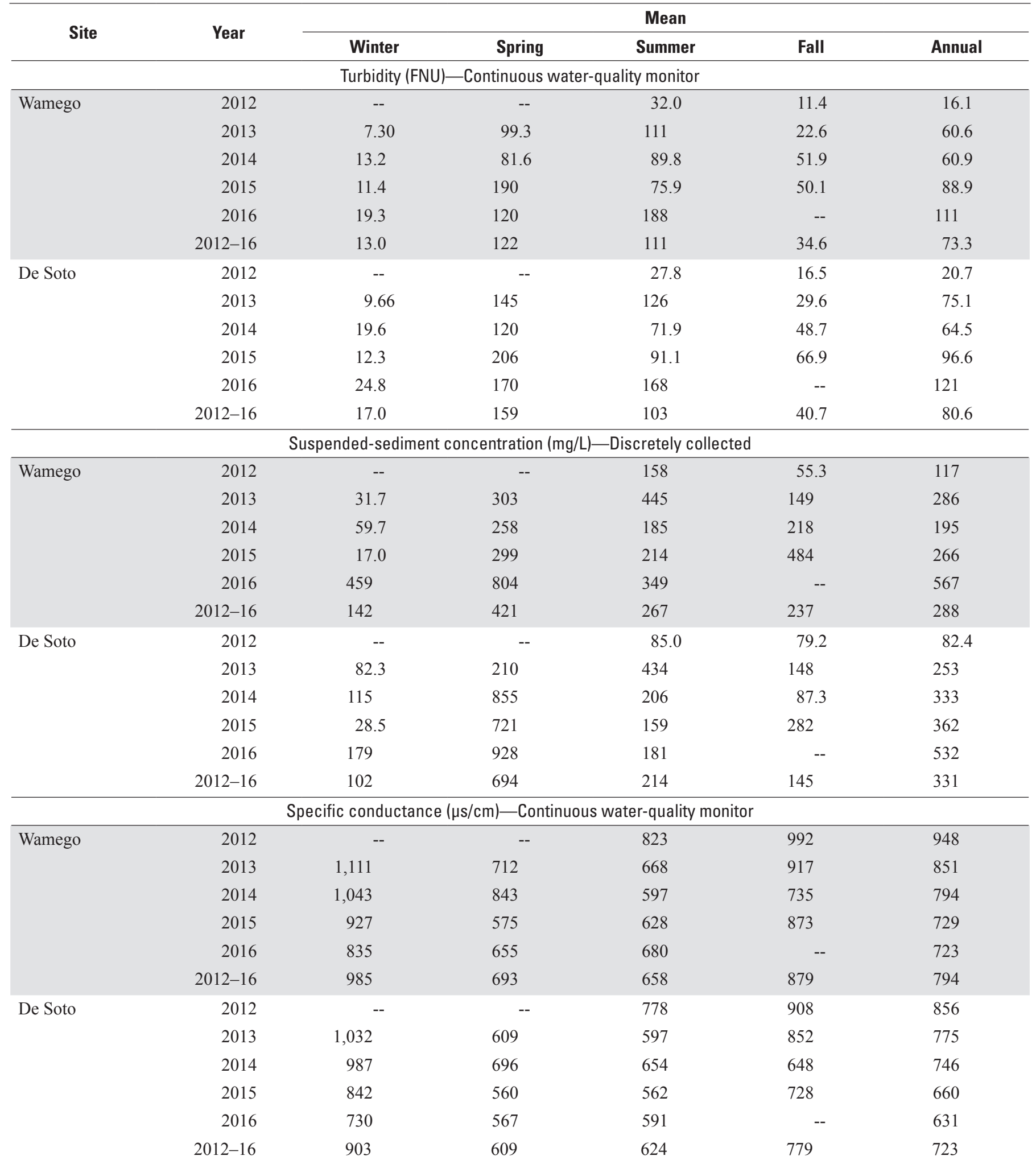


Table 2. Seasonal and annual means for discretely collected and continuously measured water-quality constituents at the Kansas River at Wamego, Kansas, and Kansas River at De Soto, Kansas, streamgages (U.S. Geological Survey stations 06887500 and 06892350 , respectively) during July 2012 through September 2016.-Continued

[winter, January through March; spring, April through June; summer, July through September; fall, October through December; ${ }^{\circ} \mathrm{C}$, degrees Celsius; --, no data; $\mathrm{mg} / \mathrm{L}$, milligram per liter; FNU, formazin nephelometric unit; $\mu \mathrm{s} / \mathrm{cm}$, microsiemen per centimeter at $25^{\circ} \mathrm{C}$; *, indicates that the mean value was calculated using one or more censored values (less than the minimum reporting limit), and censored values were substituted with a value one-half of the minimum reporting limit; CFU/100 mL, colony forming unit per 100 milliliters; colonies $/ \mathrm{mL}$, colonies per milliliter; $\mu \mathrm{g} / \mathrm{L}$, microgram per liter]

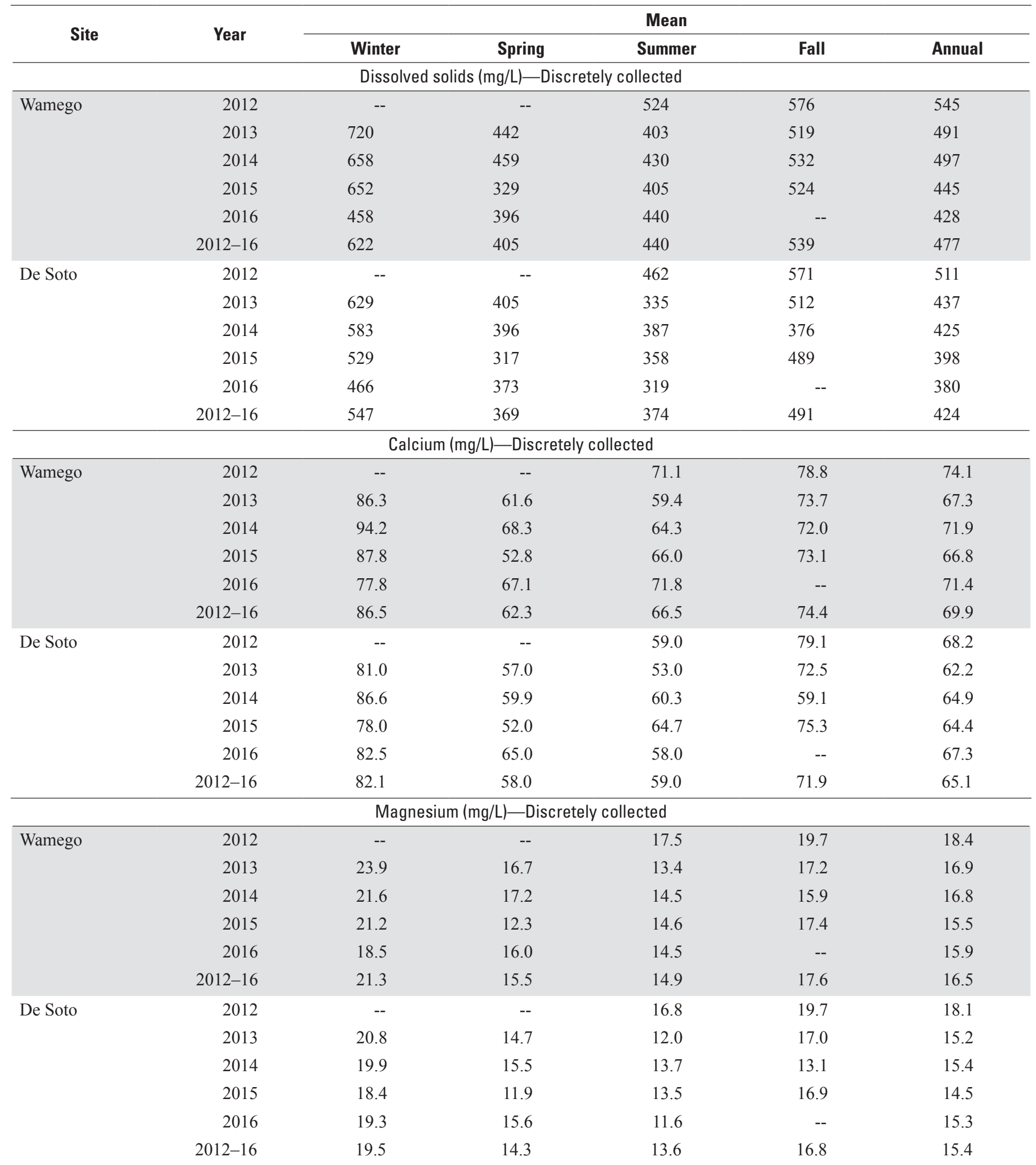


Table 2. Seasonal and annual means for discretely collected and continuously measured water-quality constituents at the Kansas River at Wamego, Kansas, and Kansas River at De Soto, Kansas, streamgages (U.S. Geological Survey stations 06887500 and 06892350 , respectively) during July 2012 through September 2016.-Continued

[winter, January through March; spring, April through June; summer, July through September; fall, October through December; ${ }^{\circ} \mathrm{C}$, degrees Celsius; --, no data; $\mathrm{mg} / \mathrm{L}$, milligram per liter; FNU, formazin nephelometric unit; $\mu \mathrm{s} / \mathrm{cm}$, microsiemen per centimeter at $25^{\circ} \mathrm{C}$; ${ }^{*}$, indicates that the mean value was calculated using one or more censored values (less than the minimum reporting limit), and censored values were substituted with a value one-half of the minimum reporting limit; CFU/100 mL, colony forming unit per 100 milliliters; colonies $/ \mathrm{mL}$, colonies per milliliter; $\mu \mathrm{g} / \mathrm{L}$, microgram per liter]

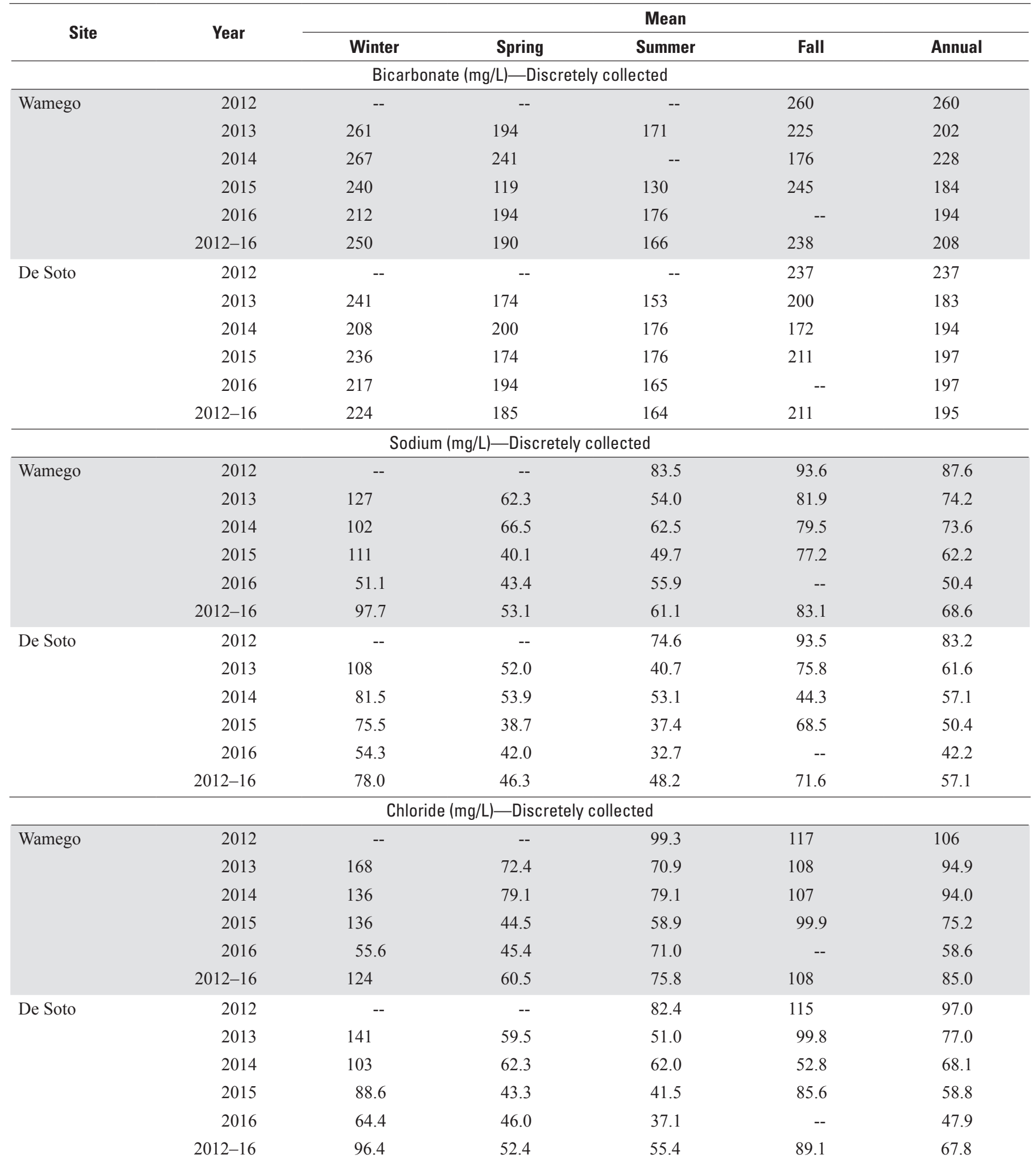


Table 2. Seasonal and annual means for discretely collected and continuously measured water-quality constituents at the Kansas River at Wamego, Kansas, and Kansas River at De Soto, Kansas, streamgages (U.S. Geological Survey stations 06887500 and 06892350 , respectively) during July 2012 through September 2016.-Continued

[winter, January through March; spring, April through June; summer, July through September; fall, October through December; ${ }^{\circ} \mathrm{C}$, degrees Celsius; --, no data; $\mathrm{mg} / \mathrm{L}$, milligram per liter; FNU, formazin nephelometric unit; $\mu \mathrm{s} / \mathrm{cm}$, microsiemen per centimeter at $25^{\circ} \mathrm{C}$; *, indicates that the mean value was calculated using one or more censored values (less than the minimum reporting limit), and censored values were substituted with a value one-half of the minimum reporting limit; CFU/100 mL, colony forming unit per 100 milliliters; colonies $/ \mathrm{mL}$, colonies per milliliter; $\mu \mathrm{g} / \mathrm{L}$, microgram per liter]

\begin{tabular}{|c|c|c|c|c|c|c|}
\hline \multirow{2}{*}{ Site } & \multirow{2}{*}{ Year } & \multicolumn{5}{|c|}{ Mean } \\
\hline & & Winter & Spring & Summer & Fall & Annual \\
\hline \multicolumn{7}{|c|}{ Potassium (mg/L)_Discretely collected } \\
\hline \multirow{3}{*}{ Wamego } & 2013 & 8.37 & 8.06 & 8.70 & 9.38 & 8.57 \\
\hline & 2014 & 8.44 & 8.16 & 10.1 & 10.7 & 9.36 \\
\hline & $2012-16$ & 8.75 & 8.37 & 9.82 & 9.70 & 9.23 \\
\hline \multirow[t]{3}{*}{ De Soto } & 2012 & -- & -- & 9.83 & 9.41 & 9.64 \\
\hline & 2013 & 8.18 & 6.88 & 8.02 & 8.96 & 7.82 \\
\hline & 2014 & 8.53 & 7.26 & 10.1 & 8.38 & 8.52 \\
\hline \multicolumn{7}{|c|}{ Sulfate (mg/L)-Discretely collected } \\
\hline \multirow[t]{6}{*}{ Wamego } & 2012 & -- & -- & 99.6 & 106 & 102 \\
\hline & 2013 & 156 & 96.2 & 83.9 & 101 & 103 \\
\hline & 2014 & 140 & 93.9 & 81.7 & 108 & 100 \\
\hline & 2015 & 139 & 64.8 & 80.4 & 101 & 89.1 \\
\hline & 2016 & 97.8 & 84.4 & 92.3 & -- & 90.6 \\
\hline & $2012-16$ & 133 & 84.3 & 87.6 & 104 & 96.7 \\
\hline De Soto & 2012 & -- & -- & 95.9 & 115 & 105 \\
\hline \multirow[t]{6}{*}{ Wamego } & 2012 & -- & -- & 1.63 & 1.18 & 1.45 \\
\hline & 2013 & 0.854 & $2.59 *$ & $1.81 *$ & 1.40 & $1.80^{*}$ \\
\hline & 2014 & 1.51 & 1.92 & 1.60 & 1.91 & 1.75 \\
\hline & 2015 & 1.41 & 2.45 & 1.63 & 1.86 & 1.91 \\
\hline & 2016 & 2.28 & 3.03 & 2.19 & -- & 2.51 \\
\hline & $2012-16$ & 1.51 & $2.47 *$ & $1.77 *$ & 1.60 & $1.89 *$ \\
\hline \multirow[t]{6}{*}{ De Soto } & 2012 & -- & -- & $1.37^{*}$ & 1.33 & $1.35^{*}$ \\
\hline & 2013 & 1.38 & $2.34 *$ & $2.13 *$ & $1.42 *$ & $1.96^{*}$ \\
\hline & 2014 & $1.73 *$ & $2.68 *$ & $1.80 *$ & 1.66 & $2.05^{*}$ \\
\hline & 2015 & 1.55 & $2.71 *$ & $1.54 *$ & $1.49 *$ & $1.96^{*}$ \\
\hline & 2016 & $1.65^{*}$ & $2.64 *$ & $2.18^{*}$ & -- & $2.24^{*}$ \\
\hline & $2012-16$ & $1.59 *$ & $2.61^{*}$ & $1.81^{*}$ & $1.47^{*}$ & $1.96^{*}$ \\
\hline
\end{tabular}


Table 2. Seasonal and annual means for discretely collected and continuously measured water-quality constituents at the Kansas River at Wamego, Kansas, and Kansas River at De Soto, Kansas, streamgages (U.S. Geological Survey stations 06887500 and 06892350 , respectively) during July 2012 through September 2016.-Continued

[winter, January through March; spring, April through June; summer, July through September; fall, October through December; ${ }^{\circ} \mathrm{C}$, degrees Celsius; --, no data; $\mathrm{mg} / \mathrm{L}$, milligram per liter; FNU, formazin nephelometric unit; $\mu \mathrm{s} / \mathrm{cm}$, microsiemen per centimeter at $25^{\circ} \mathrm{C}$; ${ }^{*}$, indicates that the mean value was calculated using one or more censored values (less than the minimum reporting limit), and censored values were substituted with a value one-half of the minimum reporting limit; CFU/100 mL, colony forming unit per 100 milliliters; colonies/mL, colonies per milliliter; $\mu \mathrm{g} / \mathrm{L}$, microgram per liter]

\begin{tabular}{|c|c|c|c|c|c|c|}
\hline \multirow{2}{*}{ Site } & \multirow{2}{*}{ Year } & \multicolumn{5}{|c|}{ Mean } \\
\hline & & Winter & Spring & Summer & Fall & Annual \\
\hline \multicolumn{7}{|c|}{ Total phosphorus (mg/L)_Discretely collected } \\
\hline \multirow{4}{*}{ Wamego } & 2013 & 0.142 & 0.440 & 0.505 & 0.324 & 0.390 \\
\hline & 2014 & 0.247 & 0.420 & 0.445 & 0.517 & 0.421 \\
\hline & 2016 & 0.368 & 0.547 & 0.592 & -- & 0.528 \\
\hline & $2012-16$ & 0.279 & 0.494 & 0.479 & 0.428 & 0.443 \\
\hline \multirow[t]{3}{*}{ De Soto } & 2012 & -- & -- & 0.318 & 0.281 & 0.301 \\
\hline & 2013 & 0.213 & 0.388 & 0.596 & 0.321 & 0.417 \\
\hline & 2014 & 0.276 & 0.687 & 0.497 & 0.414 & 0.502 \\
\hline \multicolumn{7}{|c|}{ Nitrate (mg/L)—Discretely collected } \\
\hline \multirow[t]{6}{*}{ Wamego } & 2012 & -- & -- & 0.620 & 0.549 & 0.592 \\
\hline & 2013 & 0.211 & $0.957^{*}$ & $0.583^{*}$ & 0.716 & $0.651^{*}$ \\
\hline & 2014 & 0.920 & $0.561 *$ & 0.534 & 1.02 & $0.705^{*}$ \\
\hline & 2015 & 0.727 & $1.17 *$ & $0.704^{*}$ & 0.447 & $0.801^{*}$ \\
\hline & 2016 & 1.39 & $1.67 *$ & $0.894 *$ & -- & $1.28 *$ \\
\hline & $2012-16$ & 0.811 & $1.07 *$ & $0.667 *$ & 0.680 & $0.803 *$ \\
\hline De Soto & 2012 & -- & -- & $0.0185^{*}$ & 0.342 & $0.166^{*}$ \\
\hline \multirow[t]{6}{*}{ Wamego } & 2012 & -- & -- & 0.00834 & 0.00793 & 0.00817 \\
\hline & 2013 & 0.0120 & $0.0496^{*}$ & $0.00661 *$ & 0.00381 & $0.0197 *$ \\
\hline & 2014 & 0.0229 & $0.0162 *$ & 0.00559 & 0.00396 & $0.0113^{*}$ \\
\hline & 2015 & 0.00772 & $0.0242 *$ & $0.00457 *$ & 0.00490 & $0.0113^{*}$ \\
\hline & 2016 & 0.0180 & $0.0429 *$ & $0.00294 *$ & -- & $0.0205^{*}$ \\
\hline & $2012-16$ & 0.0151 & $0.0321 *$ & $0.00561 *$ & 0.00524 & $0.0144^{*}$ \\
\hline \multirow[t]{6}{*}{ De Soto } & 2012 & -- & -- & $0.00149 *$ & 0.0102 & $0.00546^{*}$ \\
\hline & 2013 & 0.0121 & $0.0138^{*}$ & $0.00917^{*}$ & $0.00353^{*}$ & $0.0103^{*}$ \\
\hline & 2014 & 0.0884 & $0.0165 *$ & $0.00415^{*}$ & $0.00556^{*}$ & $0.0246^{*}$ \\
\hline & 2015 & 0.0120 & $0.0140^{*}$ & $0.00335^{*}$ & $0.00361 *$ & $0.00885^{*}$ \\
\hline & 2016 & $0.00665 *$ & $0.0104^{*}$ & $0.00579 *$ & -- & $0.00791 *$ \\
\hline & $2012-16$ & $0.0310^{*}$ & $0.0137 *$ & $0.00479 *$ & $0.00615^{*}$ & $0.0123 *$ \\
\hline
\end{tabular}


Table 2. Seasonal and annual means for discretely collected and continuously measured water-quality constituents at the Kansas River at Wamego, Kansas, and Kansas River at De Soto, Kansas, streamgages (U.S. Geological Survey stations 06887500 and 06892350 , respectively) during July 2012 through September 2016.-Continued

[winter, January through March; spring, April through June; summer, July through September; fall, October through December; ${ }^{\circ} \mathrm{C}$, degrees Celsius; --, no data; $\mathrm{mg} / \mathrm{L}$, milligram per liter; FNU, formazin nephelometric unit; $\mu \mathrm{s} / \mathrm{cm}$, microsiemen per centimeter at $25^{\circ} \mathrm{C}$; ${ }^{*}$, indicates that the mean value was calculated using one or more censored values (less than the minimum reporting limit), and censored values were substituted with a value one-half of the minimum reporting limit; CFU/100 mL, colony forming unit per 100 milliliters; colonies $/ \mathrm{mL}$, colonies per milliliter; $\mu \mathrm{g} / \mathrm{L}$, microgram per liter]

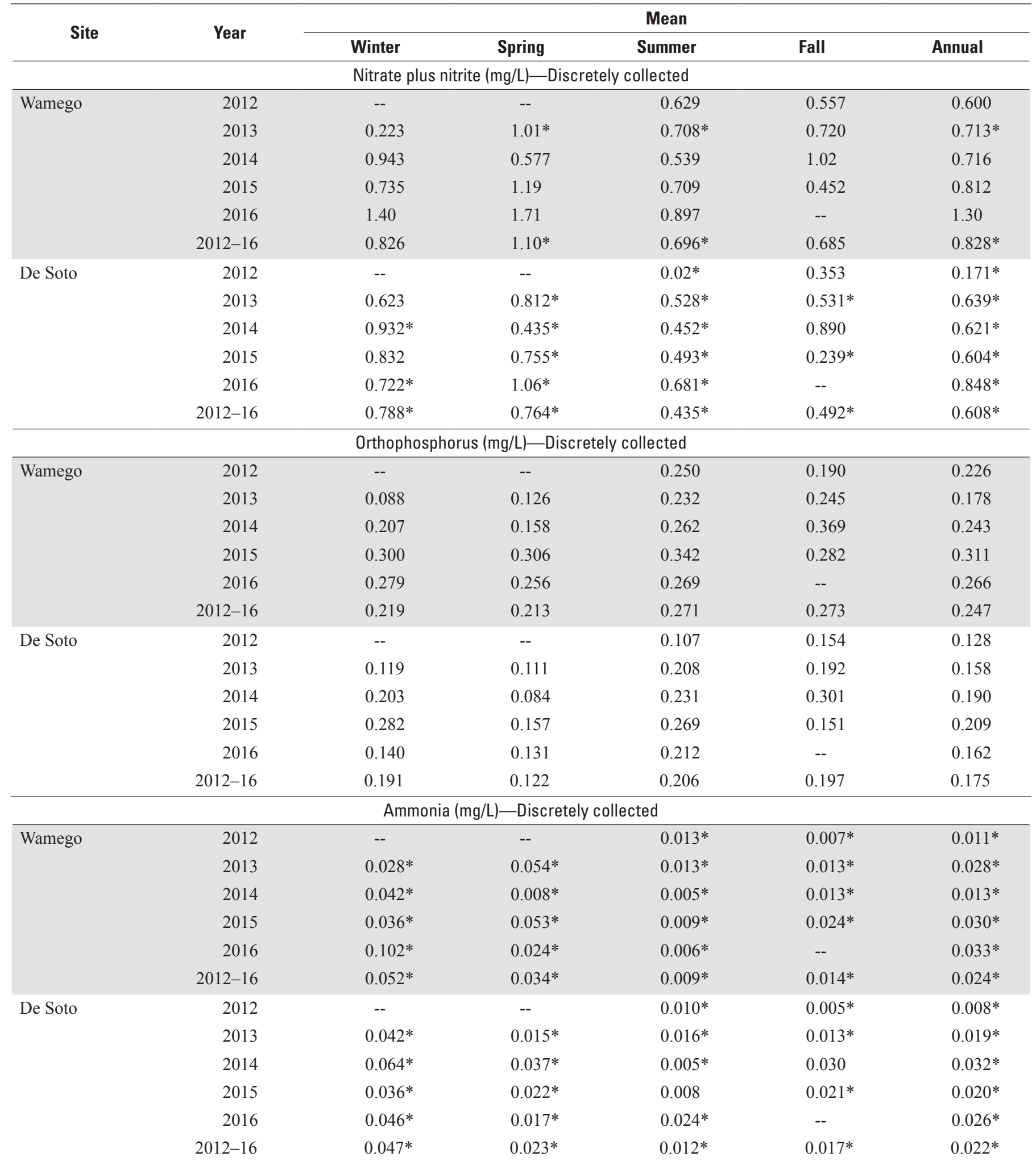


Table 2. Seasonal and annual means for discretely collected and continuously measured water-quality constituents at the Kansas River at Wamego, Kansas, and Kansas River at De Soto, Kansas, streamgages (U.S. Geological Survey stations 06887500 and 06892350 , respectively) during July 2012 through September 2016.-Continued

[winter, January through March; spring, April through June; summer, July through September; fall, October through December; ${ }^{\circ} \mathrm{C}$, degrees Celsius; --, no data; $\mathrm{mg} / \mathrm{L}$, milligram per liter; FNU, formazin nephelometric unit; $\mu \mathrm{s} / \mathrm{cm}$, microsiemen per centimeter at $25^{\circ} \mathrm{C}$; ${ }^{*}$, indicates that the mean value was calculated using one or more censored values (less than the minimum reporting limit), and censored values were substituted with a value one-half of the minimum reporting limit; CFU/100 mL, colony forming unit per 100 milliliters; colonies $/ \mathrm{mL}$, colonies per milliliter; $\mu \mathrm{g} / \mathrm{L}$, microgram per liter]

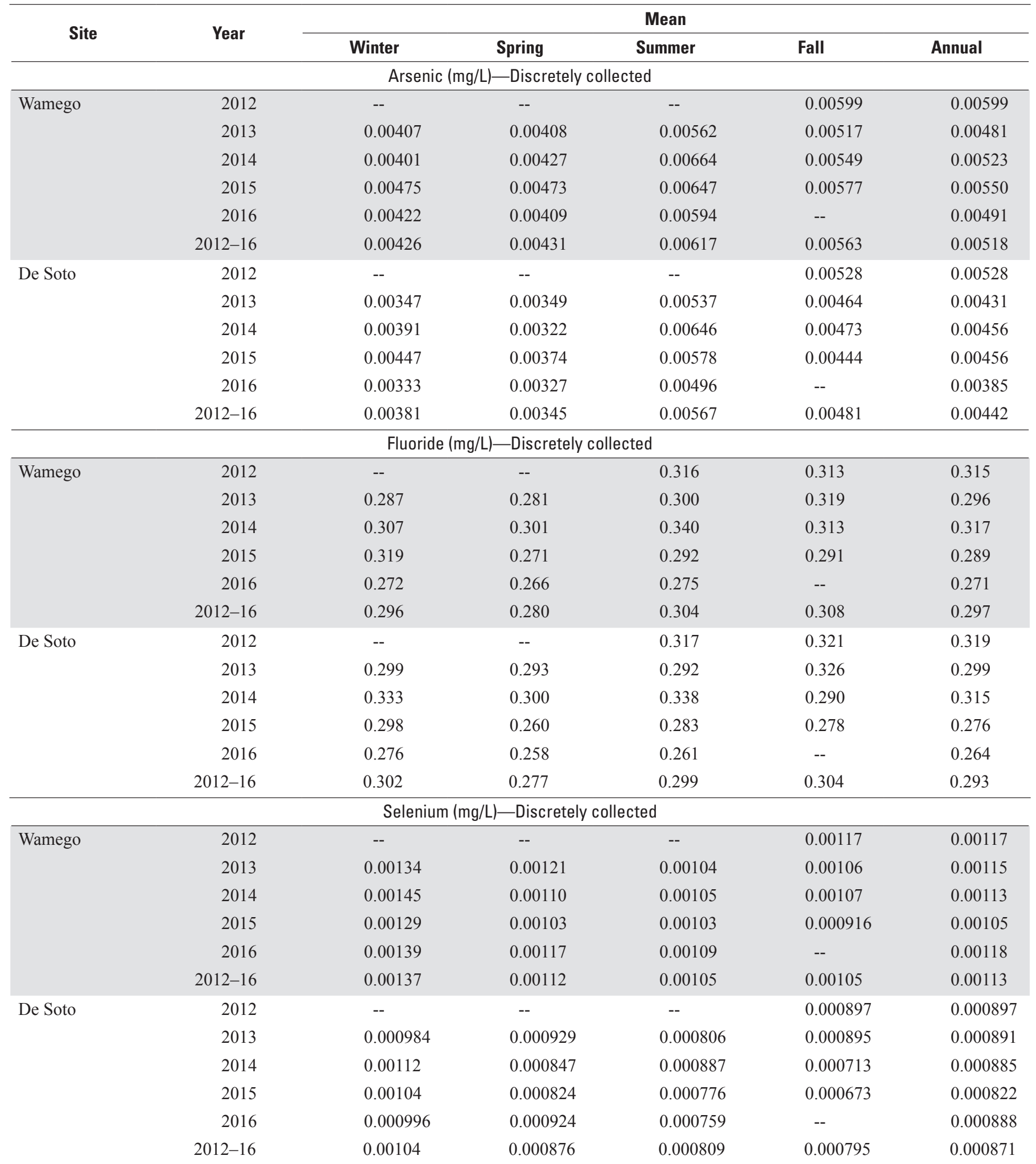




\section{Cyanobacteria and Associated Toxins and Taste-and-Odor Compounds in the Kansas River, Kansas}

Table 2. Seasonal and annual means for discretely collected and continuously measured water-quality constituents at the Kansas River at Wamego, Kansas, and Kansas River at De Soto, Kansas, streamgages (U.S. Geological Survey stations 06887500 and 06892350 , respectively) during July 2012 through September 2016.-Continued

[winter, January through March; spring, April through June; summer, July through September; fall, October through December; ${ }^{\circ} \mathrm{C}$, degrees Celsius; --, no data; $\mathrm{mg} / \mathrm{L}$, milligram per liter; FNU, formazin nephelometric unit; $\mu \mathrm{s} / \mathrm{cm}$, microsiemen per centimeter at $25^{\circ} \mathrm{C}$; *, indicates that the mean value was calculated using one or more censored values (less than the minimum reporting limit), and censored values were substituted with a value one-half of the minimum reporting limit; CFU/100 mL, colony forming unit per 100 milliliters; colonies $/ \mathrm{mL}$, colonies per milliliter; $\mu \mathrm{g} / \mathrm{L}$, microgram per liter]

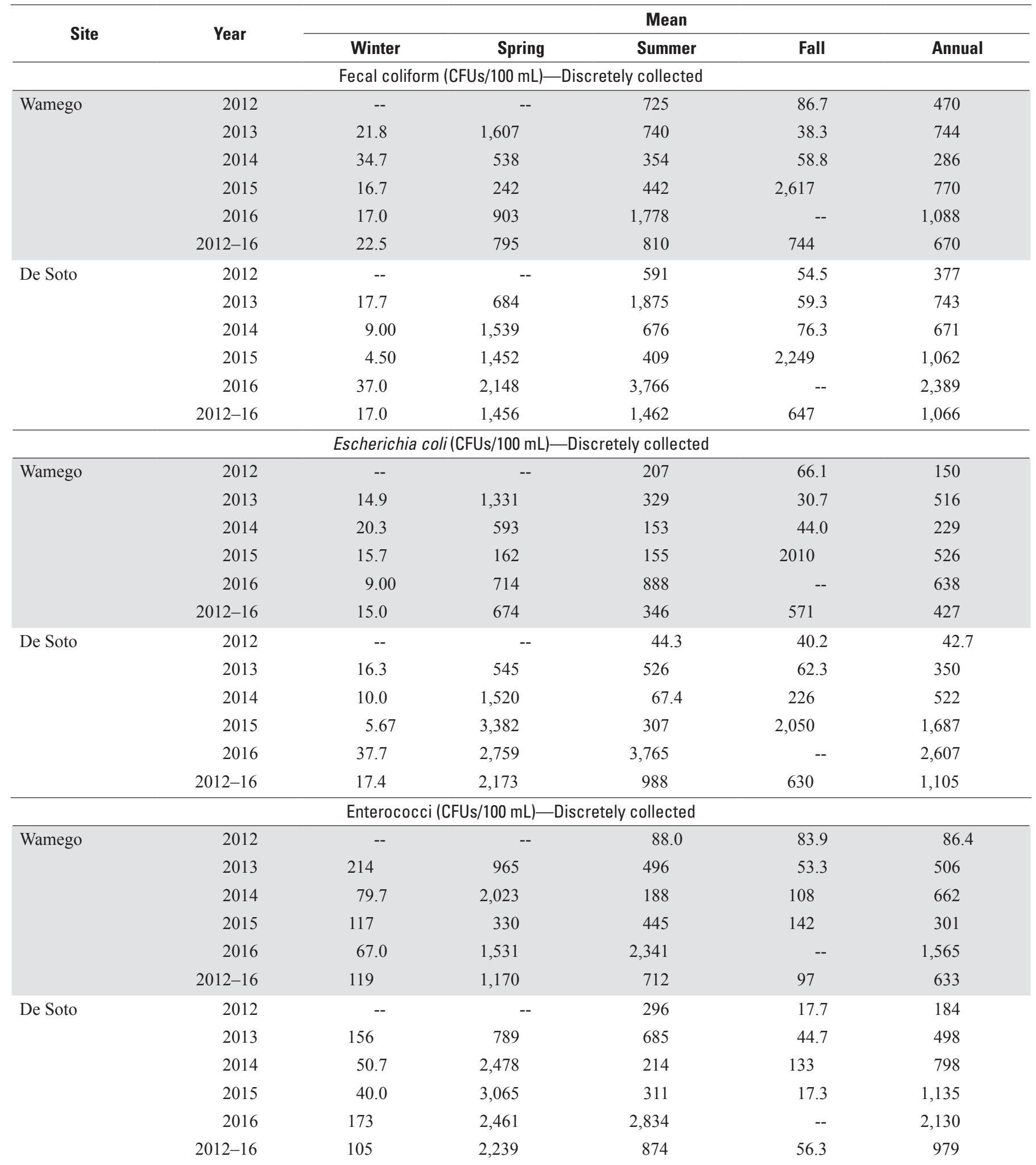


Table 2. Seasonal and annual means for discretely collected and continuously measured water-quality constituents at the Kansas River at Wamego, Kansas, and Kansas River at De Soto, Kansas, streamgages (U.S. Geological Survey stations 06887500 and 06892350 , respectively) during July 2012 through September 2016.-Continued

[winter, January through March; spring, April through June; summer, July through September; fall, October through December; ${ }^{\circ} \mathrm{C}$, degrees Celsius; --, no data; $\mathrm{mg} / \mathrm{L}$, milligram per liter; FNU, formazin nephelometric unit; $\mu \mathrm{s} / \mathrm{cm}$, microsiemen per centimeter at $25^{\circ} \mathrm{C}$; ${ }^{*}$, indicates that the mean value was calculated using one or more censored values (less than the minimum reporting limit), and censored values were substituted with a value one-half of the minimum reporting limit; CFU/100 mL, colony forming unit per 100 milliliters; colonies/mL, colonies per milliliter; $\mu \mathrm{g} / \mathrm{L}$, microgram per liter]

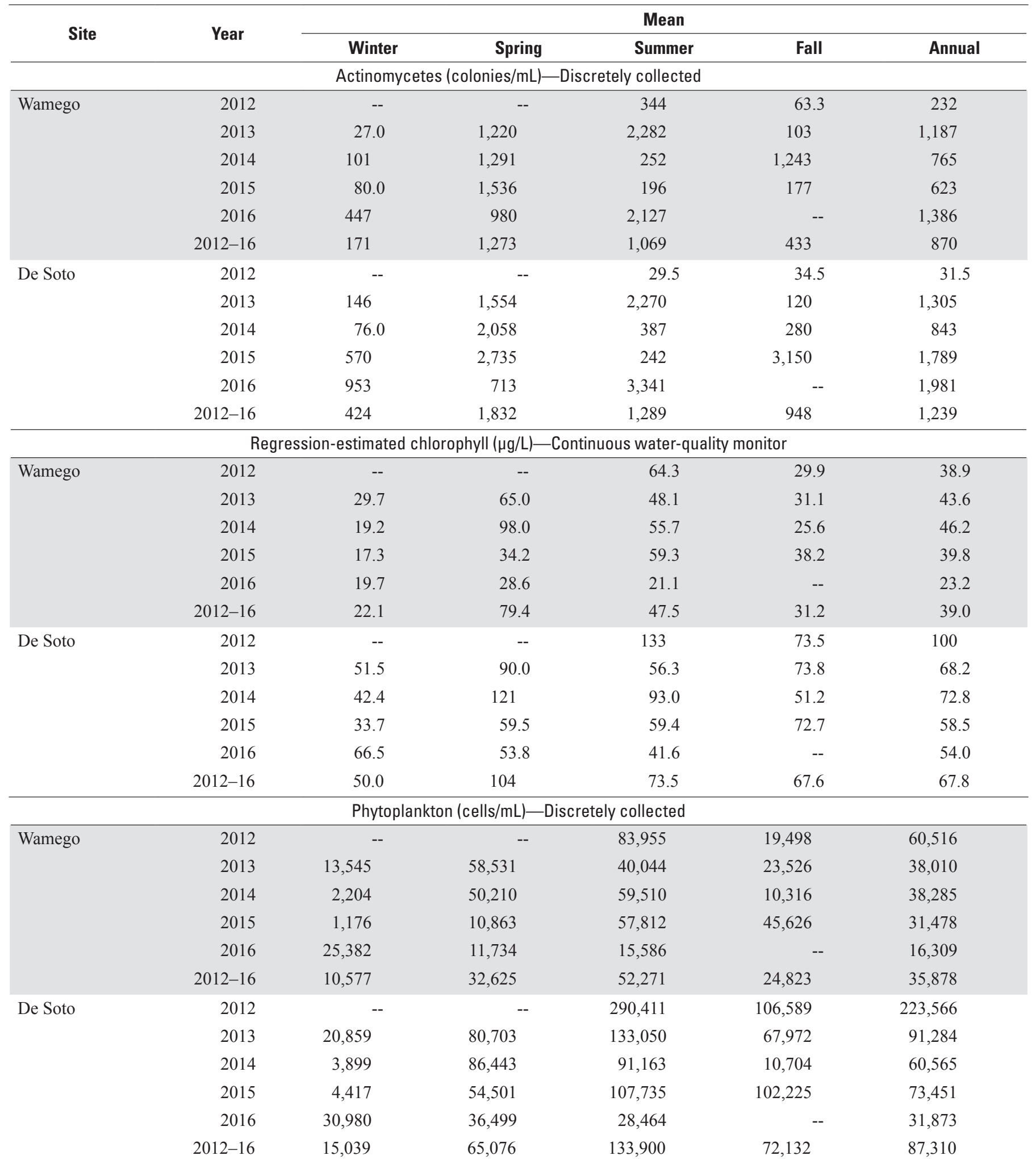




\section{Cyanobacteria and Associated Toxins and Taste-and-Odor Compounds in the Kansas River, Kansas}

Table 2. Seasonal and annual means for discretely collected and continuously measured water-quality constituents at the Kansas River at Wamego, Kansas, and Kansas River at De Soto, Kansas, streamgages (U.S. Geological Survey stations 06887500 and 06892350 , respectively) during July 2012 through September 2016. - Continued

[winter, January through March; spring, April through June; summer, July through September; fall, October through December; ${ }^{\circ} \mathrm{C}$, degrees Celsius; --, no data; $\mathrm{mg} / \mathrm{L}$, milligram per liter; FNU, formazin nephelometric unit; $\mu \mathrm{s} / \mathrm{cm}$, microsiemen per centimeter at $25^{\circ} \mathrm{C}$; ${ }^{*}$, indicates that the mean value was calculated using one or more censored values (less than the minimum reporting limit), and censored values were substituted with a value one-half of the minimum reporting limit; CFU/100 mL, colony forming unit per 100 milliliters; colonies $/ \mathrm{mL}$, colonies per milliliter; $\mu \mathrm{g} / \mathrm{L}$, microgram per liter]

\begin{tabular}{|c|c|c|c|c|c|c|}
\hline \multirow{2}{*}{ Site } & \multirow{2}{*}{ Year } & \multicolumn{5}{|c|}{ Mean } \\
\hline & & Winter & Spring & Summer & Fall & Annual \\
\hline \multicolumn{7}{|c|}{ Cyanobacteria (cells $/ \mathrm{mL}$ )—Discretely collected } \\
\hline \multirow{4}{*}{ Wamego } & 2013 & 1,504 & 2,057 & 3,737 & 102 & 2,292 \\
\hline & 2014 & 207 & 1,094 & 12,299 & 90.8 & 4,682 \\
\hline & 2016 & 12.3 & 1,002 & 194 & -- & 444 \\
\hline & $2012-16$ & 456 & 1,012 & 11,018 & 1,252 & 5,002 \\
\hline \multirow[t]{3}{*}{ De Soto } & 2012 & -- & -- & 103,257 & 3,285 & 66,903 \\
\hline & 2013 & 954 & 4,764 & 36,934 & 106 & 16,972 \\
\hline & $2012-16$ & 606 & 2,404 & 40,664 & 9,555 & 19,109 \\
\hline
\end{tabular}

${ }^{1}$ Calculated as the sum of ammonia plus organic nitrogen and nitrite plus nitrate nitrogen. 


\section{Appendixes 1-6}

Appendixes 1-6 are available at https://doi.org/10.3133/sir20185089. 
For more information about this publication, contact

Director, USGS Kansas Water Science Center

1217 Biltmore Drive

Lawrence, KS 66049

(785) 842-9909

For additional information visit https://www.usgs.gov/centers/kswsc

Publishing support provided by the

Rolla Publishing Service Center 



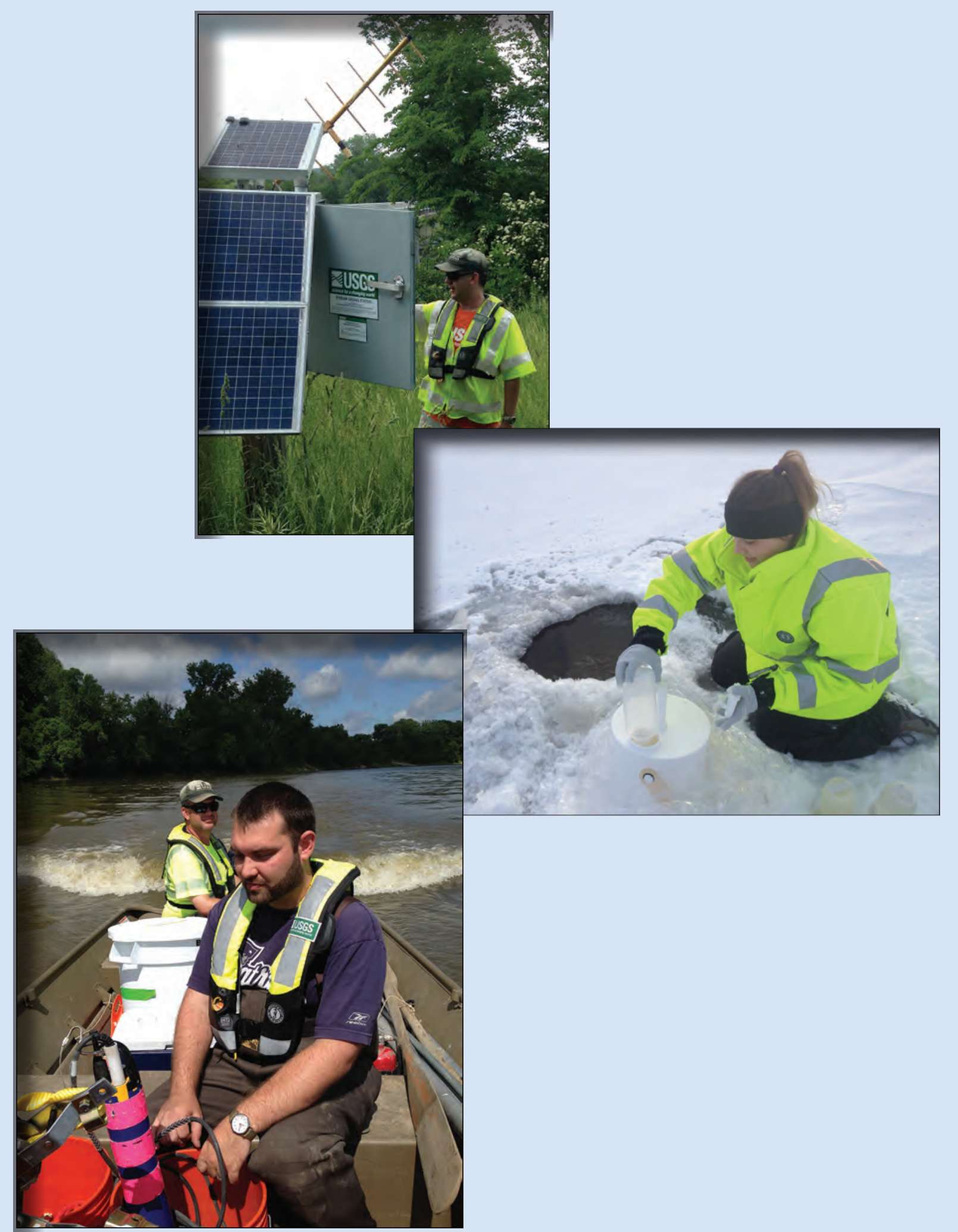

